Carla Romanelli

\title{
"AVALIAÇÃO AMBIENTAL ESTRATÉGICA COMO INSTRUMENTO PARA IMPLANTAÇÃO DE PROGRAMAS HABITACIONAIS - UM ESTUDO SOBRE O MINHA CASA MINHA VIDA."
}

Dissertação apresentada à Escola Politécnica da Universidade de São Paulo para obtenção do título de mestre.

São Paulo 
Carla Romanelli

\section{"AVALIAÇÃO AMBIENTAL ESTRATÉGICA COMO INSTRUMENTO PARA IMPLANTAÇÃO DE PROGRAMAS HABITACIONAIS - UM ESTUDO SOBRE O MINHA CASA MINHA VIDA."}

Dissertação apresentada à Escola Politécnica da Universidade de São Paulo para obtenção do título de mestre.

Área de Concentração: Engenharia de Construção Civil e Urbana.

Orientador: Prof. Dr. Alex Kenya Abiko.

São Paulo 
AUTORIZO A REPRODUÇÃO E DIVULGAÇÃO TOTAL OU PARCIAL DESTE TRABALHO, POR QUALQUER MEIO CONVENCIONAL OU ELETRÔNICO, PARA FINS DE ESTUDO E PESQUISA, DESDE QUE CITADA A FONTE.

\section{FICHA CATALOGRÁFICA}

Romanelli, Carla

Avaliação ambiental estratégica como instrumento para implantação de programas habitacionais: um estudo sobre o Minha casa, Minha Vida / C. Romanelli. -- São Paulo, 2013. $155 \mathrm{p}$.

Dissertação (Mestrado) - Escola Politécnica da Universidade de São Paulo. Departamento de Engenharia de Construção Civil.

1.Habitação popular 2.Planejamento ambiental (Avaliação) 3.Planejamento territorial urbano I.Universidade de São Paulo. Escola Politécnica. Departamento de Engenharia de Construção Civil II.t. 

Dedico este trabalho à todos que, direta ou indiretamente, colaboraram para sua elaboração, com especial atenção aos meus pais, Felipe, Marcelo e Alex. 
Foram muitas mudanças nestes três anos de desenvolvimento do mestrado. Em todas elas, sejam de ordem pessoal, empírica ou analítica, pude contar com o apoio dos Profs Alex e Marcelo Montaño. $\mathrm{Eu}$ os agradeço profundamente, sobretudo, pela paciência frente às minhas inquietações e ansiedades, persistência e incentivo, sem os quais esse trabalho não seria possível.

Agradeço ao Professor Marcelo Pereira pelos ensinamentos, orientações e incentivos constantes, determinantes para a realização dessa dissertação.

Aos meus pais e família pelo apoio permanente.

Ao Felipe pelo companheirismo e carinho.

À Wandréia e Eliany, do serviço de Pós Graduação da Engenharia da Poli, USP.

Ao Carlos Eduardo Gomes Souza e Jair Garcia, do Ministério das Cidades pelas informações fornecidas.

À Capes pelo apoio financeiro concedido, fundamental para o desenvolvimento da pesquisa. 

Essa pesquisa estuda as contribuições e potencialidades da Avaliação Ambiental Estratégica (AAE) como instrumento de planejamento urbano-territorial capaz de sugerir a implementação econômica, social e ambientalmente sustentável de políticas, planos e programas habitacionais e de prevenir os impactos socioambientais decorrentes, resultando na contribuição para sustentabilidade do desenvolvimento urbano. O objetivo do trabalho é avaliar o Programa Minha Casa Minha Vida no Brasil e as possíveis contribuições da AAE para a tomada de decisão sobre o programa habitacional em questão. Desse modo, a AAE é analisada como potencial instrumento para assegurar a integração ambiental com o planejamento estratégico do setor habitacional, utilizando, como estudo de caso, o programa Minha Casa Minha Vida (PMCMV). Através da construção de moradias, o PMCMV visa incrementar a indústria da construção civil, criando empregos e contribuindo para a movimentação econômica do país. Entretanto, muitas vezes, o programa é implantado em áreas urbanas sem a devida infraestrutura e os serviços necessários, provocando, muitas vezes, a deterioração ambiental e social da região. Esta pesquisa conclui que a sistemática da AAE para implementar os princípios do desenvolvimento sustentável no PMCMV é, senão essencial, recomendável para a tomada de decisão, pois considera as variáveis ambientais sociais e econômicas nas etapas de planejamento.

Palavras chave: Avaliação Ambiental Estratégica, Habitação Social, Planejamento Ambiental e Urbano, Programa Habitacional, Minha Casa Minha Vida. 


\section{STRATEGIC ENVIRONMENTAL ASSESSMENT AS A TOOL FOR IMPLEMENTATION OF PROGRAMS} HOUSING - A STUDY ON MY HOUSE MY LIFE

This research studies the contributions and potential of the Strategic Environmental Assessment (SEA) as a tool for urban planning for ensuring economic implementation, social and environmental sustainability of policies, plans and housing programs, as well as preventing environmental impacts, resulting in the contribution to sustainable urban development. The objective of this paper is to evaluate the Minha Casa Minha Vida program in Brazil, and the possible contributions of SEA to decision-making regarding this housing program. Thus, SEA is analyzed as a potential instrument to guarantee environmental integration with the strategic planning of the housing sector, using, as a case study, the Minha Casa Minha Vida program (PMCMV). Through the construction of houses, the PMCMV aims to stimulate the construction industry, creating jobs and contributing to the increase of economic activity in the country. However, sometimes the program is deployed in urban areas without adequate infrastructure and services, causing environmental and social deterioration of the region. This research concludes that the SEA process to implement sustainable development principles in the PMCMV is highly recommended, if not essential, to decision-making, since it considers the environmental, social and economic variables during planning phases.

Keywords: Strategic Environmental Assessment, Social Housing, Urban and Environmental Planning, Housing Policy, Minha Casa Minha Vida. 
AAE

AEB

AIA

Bacen

BNDES

$\mathrm{BNH}$

CAIXA

CADIN

CBIC

EO

FAR

FCP

FDS

FGTS

FJP

IAIA

IBGE

IPEA

LS

MMA

MDU

PAC

PMCMV

PNAD

$\mathrm{PNH}$

PNHU

PNHR

PPPs

SBPE

SEDU

SFH

SM

SNH

ZEIS
Avaliação Ambiental Estratégica

Anuário Estatístico do Brasil

Avaliação de Impacto Ambiental

Banco Central do Brasil

Banco Nacional de

Banco Nacional da Habitação (BNH)

Caixa Econômica Federal

Cadastro Informativo

Câmara Brasileira da Indústria da Construção

Entidade Organizadora

Fundo de Arrendamento Residencial

Fundação Da Casa Popular

Fundo de Desenvolvimento Social

Fundo de Garantia por Tempo de Serviço

Fundação João Pinheiro

International Association for Impact Assessment

Instituto Brasileiro de Geografia e Estatística

Instituto de Pesquisa Econômica Aplicada

Licença Ambiental Simplificada

Ministério do Meio Ambiente

Ministério do Desenvolvimento Urbano e do Meio Ambiente

Programa de Aceleração do Crescimento

Programa Minha Casa Minha Vida

Pesquisa Nacional por Amostra de Domicílios

Política Nacional de Habitação

Programa Nacional de Habitação Urbana

Programa Nacional de Habitação Rural

Políticas, Planos e Programas

Sistema Brasileiro de Poupança e Empréstimo

Secretaria Especial de Desenvolvimento Urbano

Sistema Financeiro de Habitação

Salário Mínimo

Secretaria Nacional da Habitação

Zonas Especiais de Interesse Social 


\section{LISTA DE TABELAS}

TABELA 1: DÉFICIT HABITACIONAL BRASILEIRO EM 2008.

TABELA 2: EVOLUÇÃO DO DÉFICIT HABITACIONAL URBANO NO BRASIL ENTRE 2000 E 2008. .28

TABELA 3: FAMÍLIA POR FAIXA ESTÁRIA DO CHEFE - BRASIL .31

TABELA 4: NECESSIDADES DE NOVAS MORADIAS - 2010 A 2022. .32

TABELA 5: DOMICÍLIOS VAGOS COM POTENCIAL PARA SEREM HABITADOS EM 2008. .33

TABELA 6: VALOR MÁXIMO DE AQUISIÇÃO DAS UNIDADES.

TABELA 7: VALOR MÁXIMO DE AQUISIÇÃO PARA FAMÍLIAS COM RENDA ENTRE 3 E 10 SM. 54

TABELA 8: PASSOS MAIS UTILIZADOS NA APLICAÇÃO DA AAE PARA PPPS.

TABELA 9: DISTRIBUIÇÃO DOS EMPREENDIMENTOS DO PMCMV

\section{LISTA DE FIGURAS}

FIGURA 1: FLUXOGRAMA DA PRODUÇÃO DAS UNIDADES VIA CONSTRUTORA.

FIGURA 2: FLUXOGRAMA DA PRODUÇÃO DAS UNIDADES VIA DOAÇÃO DE TERRA PELO MUNICÍPIO.......50

FIGURA 3: FLUXOGRAMA DA PRODUÇÃO DAS UNIDADES VIA ENTIDADES ORGANIZADORAS.

FIGURA 4: TIPOLOGIA PADRÃO DE CASA TÉRREA PARA FAMÍLIAS COM RENDA ATÉ 3 SM

FIGURA 5: TIPOLOGIA PADRÃO DE APARTAMENTO PARA FAMÍLIAS COM FAIXA COM RENDA ATÉ 3 SM.

FIGURA 6: FLUXOGRAMA DA PRODUÇÃO DE UNIDADES PARA FAMÍLIAS COM RENDA ENTRE 3 E 10 SM.

FIGURA 7: ABORDAGENS OPERACIONAIS DA AVALIAÇÃO DE IMPACTO AMBIENTAL. .87

FIGURA 8: INTEGRAÇÃO DO PROCESSO DE AAE COM A ESTRUTURA DE DECISÃO .92

FIGURA 9: CONTRIBUIÇÃO DA AAE PARA EIA .95

FIGURA 10: PROCESSO DE DECISÃO ESTRATÉGICA DO PMCMV SEM A VARIÁVEL AMBIENTAL .120 FIGURA 11: PROCESSO ATUAL QUE CONDUZ AO PMCMV. 121 FIGURA 12: PMCMV BO MUNICÍPIO DE SÃO PAULO - FAIXA DE 0-3 SM. 
FIGURA 13: MAPA DO ZONEAMENTO BIOCLIMÁTICO BRASILEIRO. .126

FIGURA 14: LEGISLAÇÕES E PPPS QUE FAZEM INTERFACE COM A ESTRATÉGIA DO PMCMV POSSIBILITADA PELA AAE.

\section{LISTA DE GRÁFICOS}

GRÁFICO 1: DÉFICIT HABITACIONAL URBANO POR FAIXAS DE RENDA MÉDIA FAMILIAR MENSAL, EM SALÁRIOS MÍNIMOS (\$M) - BRASIL - 2008.

GRÁFICO 2: DISTRIBUIÇÃO DO DÉFICIT HABITACIONAL, POR SITUAÇÃO DE DOMICÍLIO, SEGUNDO REGIÕES GEOGRÁFICAS - BRASIL - 2008

GRÁFICO 3: CRESCIMENTO DA POPULAÇÃO BRASILEIRA ENTRE 2010 E 2022. 31

GRÁFICO 4: DOMICÍLIOS COM CARÊNCIA DE INFRAESTRUTURA. 34

GRÁFICO 5: DÉFICIT HABITACIONAL X UNIDADES CONTRATADAS. .56

\section{LISTA DE QUADROS}

QUADRO 1: PRINCIPAIS MUDANÇAS ENTRE O MCMV1 E MCMV2. .57

QUADRO 2: AVALIAÇÃO AMBIENTAL DE POLÍTICAS, PLANOS, PROGRAMAS E PROJETOS. .88

QUADRO 3: PRINCIPAIS DIFERENÇAS ENTRE EIA E AAE...... .98

QUADRO 4: PRINCÍPIOS GERAIS E SETORIAIS: AAE E PMCMV. 131

QUADRO 5: QUADRO PROBLEMA PMCMV... .135

QUADRO 6: QUADRO DE GOVERNANÇA PMCMV. 135

QUADRO 7: QUADRO DE REFERÊNCIA ESTRATÉGICA. 136

QUADRO 8: QUESTÕES SETORIAIS A SEREM TRATADAS PELA AAE NO PMCMV. 137

QUADRO 9: COMPARAÇÕES ENTRE O PMCMV ATUAL E COM A POSSIBILIDADE DE APLICAÇÃO DA AAE. 
\begin{tabular}{l|ll} 
INICIAL & Introdução & 15
\end{tabular}

Objetivos 20

Metodologia $\quad 21$

Estrutura 22

CAPÍTULO1| Habitação Social no Brasil 24

Déficit Habitacional $\quad 25$

Políticas, Planos e Programas habitacionais $\quad 35$

1920-1964 - Fundação da Casa Popular 35

1964-1986 - Banco Nacional de Habitação 36

1986-2009 - Política Nacional de Habitação 39

Programa Minha Casa Minha Vida 42

Agentes e Recursos $\quad 45$

O Programa por Faixas de Renda $\quad 48$

0 a 3 salários mínimos $\quad 48$

3 a 10 salários mínimos $\quad 54$

Minha Casa Minha Vida 2

Relação com Programas Anteriores 60

Considerações sobre o Programa 62

CAPÍTULO2 $\mid$ Avaliação Ambiental 73

Planejamento Ambiental e Urbano em PPPs Habitacionais $\quad 74$

Avaliação de Impacto Ambiental $\quad 81$

Avaliação Ambiental Estratégica $\quad 85$

Objetivos da AAE 93

Diferenças entre AAE e EIA 97

Etapas 99

Aplicações Internacionais 101

Aplicações no Brasil 108

Considerações sobre AAE 111

CAPÍTULO3 AAE como Instrumento de Planejamento Territorial do PMCMV 113

$\begin{array}{ll}\text { PMCMV sem AAE } & 117\end{array}$

PMCMV com AAE 128

\begin{tabular}{l|lr} 
FINAL & Considerações Finais & 143
\end{tabular}

Referências Bibliográficas 146 

INICIAL

INTRODUÇÃO 
Desde o final do século $X X$, foram implementados diversos mecanismos legais, instrumentos metodológicos e soluções operacionais capazes de resolver problemas críticos de degradação ambiental (PARTIDÁRIO e JESUS, 1999). A Avaliação de Impacto Ambiental (AIA) consolidou-se em países desenvolvidos como instrumento preventivo de política e gestão ambiental. No entanto, a efetividade da AIA passou a ser ameaçada pela ausência de consideração das variáveis ambientais em etapas de planejamento anteriores àquela de formulação dos projetos de grandes obras públicas e empreendimentos de iniciativa privada (MMA/SQA, 2002).

Assim, a partir do entendimento de que a AIA é um instrumento, segundo MMA (2002), "cujos objetivos limitam-se a subsidiar as decisões de aprovação de projetos de empreendimentos individuais, e não os processos de planejamento de decisões políticas e estratégicas que os originam", foi proposta a realização da Avaliação Ambiental Estratégica (AAE), definida por Partidário e Clark (2001) como "procedimento sistemático e contínuo de avaliação da qualidade do meio ambiente e das conseqüências ambientais decorrentes de visões e intenções alternativas de desenvolvimento, incorporadas em iniciativas tais como a formulação de políticas, planos e programas (PPP), de modo a assegurar a integração efetiva dos aspectos biofísicos, econômicos, sociais e políticos, o mais cedo possível, aos processos públicos de planejamento e tomada de decisão."

Essa forma de se fazer um diagnóstico e um prognóstico de uma região pode se converter em um instrumento de política ambiental, capaz de promover a articulação das várias dimensões de políticas, planos e programas (PPPs) de desenvolvimento, explicitando com clareza seus objetivos e as questões ambientais e urbanas relacionadas à sua implementação. Além disto, tem a possibilidade de fornecer as orientações necessárias para a viabilização econômica, social e ambiental de determinadas atividades na área objeto da avaliação, favorecendo, deste modo, a avaliação de impactos cumulativos decorrentes das diversas ações a serem desenvolvidas (MMA/SQA, 2002).

Seu uso tem sido apoiado, na maioria dos estudos já produzidos por autores como Thérivel e Partidário (1996), Thérivel et. al. (1996), Lee e Walsh (1992), por duas razões principais: sua capacidade de minimizar as limitações do processo de Avaliação de Impacto Ambiental - AIA, e o papel que esse processo poderá representar para a promoção do desenvolvimento sustentável (EGLER, 2002).

Porém, no Brasil, o assunto ainda é tratado em canais restritos existindo uma série de desafios metodológicos e políticos para garantir a inserção do meio ambiente na tomada de decisão, sendo que as tentativas de aplicação desse instrumento ainda acontecem de modo pontual e experimental, como na exploração de gás do Gasoduto Bolívia Brasil, no plano de transportes de Brasília e no programa 
Rodoanel, em São Paulo. Isso ocorre, pois o processo de AAE necessita de metodologias específicas de acordo com a realidade a ser trabalhada.

Thérivel (2004 apud MANSUR et. al., 2007) aponta que há grandes dificuldades limitando esse processo, como o foco em assuntos limitados, sem uma visão estratégica, dos sistemas políticos de vários países, que impossibilitam a determinação dos parâmetros de sustentabilidade ambiental. Além disso, por se tratar de um nível estratégico, há uma série de tópicos que, se não bem resolvidos, deixam o processo vulnerável a questionamentos quanto à metodologia e aos critérios utilizados.

Os exemplos internacionais, expostos em Partidário e Clark (2001), mostram a necessidade de vinculação apurada à realidade local. Países com forte cultura de planejamento das políticas públicas, onde este já esteja devidamente instrumentalizado e nos quais este processo seja desenvolvido à luz de metodologias específicas, como Nova Zelândia, Holanda, Inglaterra e Canadá, podem mais facilmente contar com a AAE voltada para políticas.

No entanto, países com cultura de planejamento limitada e pouca instrumentalização nos processos de elaboração de políticas públicas, em geral, não se utilizam da avaliação ambiental para planos e programas. Assim, em países como o Brasil, se exige a consideração das suas peculiaridades e formatação de metodologias específicas (MANSUR et. al., 2007).

A compatibilização entre o crescimento econômico e a política de preservação do meio ambiente necessita ser realizada desde as primeiras fases de elaboração das políticas de desenvolvimento, a fim de permitir uma utilização racional dos recursos, e evitar que a sociedade enfrente vulnerabilidades do ponto de vista econômico e ecológico frente aos futuros danos ambientais (BURSZTYN, 1994).

Segundo Thérivel e Partidário (1996), a AAE pode ser uma forma de garantir políticas mais sustentáveis, identificando parâmetros e referências ambientais e de sustentabilidade, de forma que os objetivos e os possíveis impactos de políticas, planos e programas - PPPs estejam de acordo com essas referências.

Considerando as características de tal instrumento e tendo em vista o papel indutor de transformações territoriais em ampla escala de Programas Habitacionais e seu significativo impacto econômico, social e ambiental, pretende-se neste trabalho apresentar e discutir a potencialidade da AAE como forma de mediar conflitos de diversas ordens gerados em função da implantação de Programas Habitacionais sem o devido planejamento.

Para isso, optou-se pelo caso do Programa Minha Casa Minha Vida, do Governo Federal, lançado em abril de 2009, com a meta de construção de um milhão de moradias e apresentado como uma das 
principais ações do governo em reação à crise econômica internacional, estimulando a criação de empregos e de investimentos no setor da construção.

A habitação é um bem de primeira necessidade que depende do dispêndio de valores monetários expressivos e responde por parcela importante da atividade da indústria da construção civil no Brasil (SANTOS, 1999).

Carmo (2006) afirma que criar mecanismos que promovam o acesso para a população mais pobre à moradia é fundamental, tendo em vista que a habitação é o ativo de maior importância e de maior valor monetário para este segmento.

No Brasil, a demanda de um grande número de habitações surge como resultado das migrações do meio rural para as cidades a partir de 1950, em função da industrialização acelerada e do próprio crescimento da população brasileira. No final da década de 50 , a população urbana brasileira já era $70 \%$ maior do que no começo daquela década. O crescimento acentuado se manteve, fazendo com que a população urbana crescesse $100 \%$ em 30 anos, passando de menos de 80 milhões em 1980 para mais de 160 milhões em 2010 (IBGE, 2011). Esses números refletem a dimensão do problema gerado com a falta de habitações, provocando a proliferação de cortiços e de habitações precárias nas periferias urbanas (REIS e LAY, 2010).

Segundo a Fundação João Pinheiro - FJP (2011), o déficit habitacional era de 5,8 milhões de unidades habitacionais em 2008 , sendo quase $90 \%$ concentrado na população de renda mais baixa. Isso demonstra que a falta de moradia no Brasil encontra-se profundamente associada à pobreza e à má distribuição de renda e mostra a necessidade de construção de um grande número de habitações de interesse social para uma parcela expressiva da população. Entretanto, além dos aspectos quantitativos, é importante que os aspectos relacionados à qualidade da habitação de interesse social também sejam considerados.

Logo, além da provisão de um grande número de empreendimentos de habitação de interesse social, o setor da construção civil enfrenta outro desafio: a diminuição dos impactos ambientais, sociais e econômicos provocados pelo setor

Para ser sustentável, a habitação de interesse social deve integrar os conceitos ecológicos, sociais e econômicos e deve responder adequadamente às necessidades dos moradores em suas várias dimensões. Portanto, não basta haver sustentabilidade ecológica se não houver sustentabilidade social, ou seja, se não há adequação dos locais onde as relações sociais se desenvolvem (LEGENDRE, 2003, apud REIS e LAY, 2010).

A permanência de um elevado déficit habitacional concentrado na baixa renda depois de décadas de política habitacional, impulsionada pelo governo federal, evidencia o fracasso dos 
programas públicos e a incapacidade dos mecanismos de mercado para o enfrentamento do problema (BONDUKI, 2008). A situação, por outro lado, tem ressaltado a absoluta necessidade de se formular estratégias mais eficazes para atender as faixas de menor poder aquisitivo.

A dimensão deste problema mostra que a questão habitacional não pode ser equacionada apenas com a oferta de novas unidades, mas demanda uma ação articulada com outras políticas, planos e programas, como as políticas ambientais, urbanas, fundiárias e de saneamento.

Em diversos lugares do mundo, a produção habitacional impulsiona a urbanização do território. Dependendo das condições em que as habitações são produzidas, essa urbanização pode gerar segregação sócio-espacial, através do isolamento da população e da periferização sem acesso à infraestrutura adequada. Esse tipo de urbanização periférica traz custos adicionais aos municípios, com gastos em infra-estrutura, transportes e serviços públicos. No caso das habitações urbanas estes gastos abrangem: serviços urbanos, como abastecimento de água, coleta de esgotos, distribuição de energia elétrica, transporte coletivo; infraestrutura urbana incluindo as redes físicas de distribuição de água e coleta de esgotos, as redes de drenagem, as redes de distribuição de energia elétrica, sistema viário etc; e equipamentos sociais como, educação, saúde, lazer. (ABIKO, 1995)

Diversos autores, como Abiko (1995) e Bonduki (2009), defendem uma política de desenvolvimento urbano em longo prazo, que preveja a expansão da cidade. Assim, o planejamento urbano, uma das diretrizes do Plano Diretor, deve prever as áreas mais apropriadas para a instalação de conjuntos habitacionais.

A expansão da malha urbana deve ser levada em conta, já que muitos dos grandes municípios se aproximam da ocupação máxima de seus limites territoriais. Por isso, para que um programa habitacional tenha êxito é necessário pensar em várias alternativas e não em apenas na construção de novas unidades.

Diante deste cenário, torna-se vital uma política habitacional que esteja alinhada com a política urbana, articulada com outros PPPs e com o desenvolvimento e planejamento das cidades, sendo a questão da moradia configurada como uma das dimensões essenciais do Planejamento Estratégico, ligado ao processo de produção do espaço urbano.

Nesse sentido, o projeto da habitação de interesse social está diretamente relacionado ao planejamento ecológico, urbano, social e econômico. Projetos habitacionais sustentáveis implicariam a melhoria da qualidade de vida dos residentes mediante o uso adequado dos recursos naturais locais e uma abordagem de projeto contextual respeitando sítio, clima, características culturais e necessidades humanas (OKTAY, 1999, apud REIS e LAY, 2010). 
Conforme apresentado, as intervenções sócio-econômicas, na maioria das vezes, alteram e degradam a qualidade do ambiente, sem garantir o atendimento às necessidades básicas dos diferentes grupos da sociedade. Trata-se de um padrão sem sustentabilidade ecológica e social, que não aloca eficientemente os recursos econômicos (SACHS, 2004). Outros potenciais de aproveitamentos econômicos, que poderiam incluir socialmente estes grupos humanos, chocam-se com aqueles usos que provocam a ultrapassagem dos limites ambientais.

Apesar de haver uma vasta literatura sobre a questão ambiental, Scheidt et.al. (2010), afirmam que pouco se aborda sobre os requisitos e as diretrizes com a profundidade e a objetividade necessárias a um processo de avaliação de empreendimentos habitacionais de interesse social.

Assim, a proposição de uma ferramenta, como a Avaliação Ambiental Estratégica, que identifica os requisitos ambientais, abrangendo suas variáveis e as interações entre diferentes PPPs, além de envolver as etapas de localização, infraestrutura, projeto, implantação e pós ocupação, objetiva contribuir para nortear os responsáveis pela análise Programas habitacionais na malha urbana.

Além disso, nos últimos anos o processo de AAE vem ganhando grande reconhecimento como ferramenta na tomada de decisão, visando o desenvolvimento sustentável (THÉRIVEL, 2004 apud MANSUR et. al. 2007).

Assim, consideradas as peculiaridades e características da situação brasileira como amplos territórios ainda não ocupados ou incorporados ao processo de produção, que abrigam diferentes e complexos ecossistemas, com características peculiares de sustentabilidade; reforço dos procedimentos de planejamento dos usos do solo e ambiental, como aspecto determinante de evolução da gestão ambiental; projetos considerados como estruturantes, potencialmente capazes de produzir impactos estratégicos em regiões em desenvolvimento, entende-se que o atual estágio de conhecimento das experiências de uso da AAE nos demais países e instituições internacionais, oferecem os elementos necessários à aplicação da AAE no Brasil, especialmente no desenvolvimento e planejamento territorial urbano, como é o caso dos programas habitacionais.

\section{OBJETIVOS}

Avaliar o Programa Minha Casa Minha Vida no Brasil e as possíveis contribuições da AAE para a tomada de decisão sobre o programa habitacional em questão. 


\section{OBJETIVOS ESPECÍFICOS}

Entender o contexto do PMCMV, os números do déficit habitacional brasileiro e a história das políticas, planos e programas habitacionais que o originaram.

Avaliar as perspectivas de aplicação da AAE como possível instrumento de solução de conflitos nos programas habitacionais de interesse social, a fim de integrar as variáveis sociais e ambientais no processo de planejamento e desenvolvimento de Programas habitacionais.

\section{METODOLOGIA}

Para analisar a aplicabilidade da AAE como instrumento de Planejamento para o Programa Habitacional Minha Casa Minha Vida foram desenvolvidas as seguintes atividades:

\section{. Revisão bibliográfica}

A pesquisa bibliográfica teve como principal objetivo reconhecer o estado da arte sobre o tema, permitindo a composição conceitual e análise crítica de temas relacionados aos Programas Habitacionais brasileiros e à Avaliação Ambiental Estratégica.

Essa etapa foi realizada em livros, teses, dissertações, artigos publicados em periódicos nacionais e internacionais, consulta a anais de congressos, relatórios técnicos de estudos ambientais, legislações e regulamentações incidentes no país e reportagens.

O levantamento da revisão bibliográfica foi realizado em bases de dados digitais e também por visitas a bibliotecas de universidades para a consulta dos materiais disponíveis. Os temas-chave pesquisados foram:

- Déficit Habitacional

. Política Habitacional Brasileira

- Programa Minha Casa Minha Vida

. Planejamento Estratégico

. Avaliação Ambiental Estratégica.

A partir do levantamento bibliográfico, algumas informações foram obtidas através de informações fornecidas via email pelo Ministério das Cidades, um dos agentes responsáveis pela elaboração e aplicação do Programa Minha Casa Minha Vida, objeto de estudo desse trabalho. 
Com o objetivo de analisar as possibilidades de incorporação da AAE no Programa Minha Casa Minha Vida, foram utilizados quadros conceituais de inserção da AAE no planejamento estratégico do programa habitacional. Isso permitiu avaliar a aplicabilidade da AAE pelos diferentes níveis de governo Federal, Estadual e Municipal - na elaboração do programa, indicando suas responsabilidades e contribuições, assim como a importância do planejamento integrado entre os diferentes atores e esferas governamentais.

\section{ESTRUTURA}

O conteúdo dessa dissertação está estruturado ao longo de quatro capítulos.

A primeira parte concentra a Introdução, onde a pesquisa é contextualizada e o tema caracterizado através de parte da revisão bibliográfica. Nesse capítulo também são apresentados os objetivos, a metodologia e a estrutura do trabalho.

Para uma maior compreensão do problema e melhor avaliação do Programa pesquisado, é necessário observar a origem da política habitacional, como se implantou e foi discutida no Brasil. Assim, o sprimeiro capítulo - Habitação Social - apresenta, através de pesquisa bibliográfica, o histórico do problema habitacional entre os anos de 1920 e 2009 como uma base conceitual para o Programa em questão. O Programa Minha Casa minha Vida também é contextualizado com os números do déficit habitacional elaborados pela Fundação João Pinheiro, que atestaram a existência de um expressivo déficit habitacional quantitativo e qualitativo no Brasil, envolvendo principalmente as famílias de baixa renda. Por fim, são apresentadas as características gerais do Programa Minha Casa Minha Vida.

Para demonstrar a necessidade de um modelo de planejamento ambiental na elaboração de Programas Habitacionais, o segundo capítulo traz os conceitos de planejamento ambiental e urbano estratégico.

O capítulo também aborda a caracterização da Avaliação Ambiental Estratégica - AAE e suas potencialidades como um instrumento de planejamento ambiental e urbano. Nesse sentido, são descritos seus principais aspectos conceituais, suas etapas, histórico e aplicações.

No terceiro capítulo, a AAE é abordada como possível instrumento de planejamento para o PMCMV através de exemplos da implementação do Programa sem a ferramenta em questão e com sua inserção no planejamento estratégico. Dessa forma, a Avaliação Ambiental Estratégica é proposta como instrumento para implantação de programas habitacionais para prevenir impactos socioambientais negativos. Assim, é possível avaliar qual a importância de aplicação de AAE na elaboração do referido programa. 
A parte final aborda as principais considerações e conclusões sobre o trabalho e apresenta a discussão a respeito dos resultados obtidos, além de conter a relação de publicações consultadas para a elaboração desta pesquisa. 
CAPÍTULO 1

HABITAÇÃO SOCIAL NO BRASIL 


\section{HABITAÇÃO SOCIAL NO BRASIL}

\section{DÉFICIT HABITACIONAL}

A definição de déficit habitacional é fundamental para a elaboração das políticas habitacionais. Entretanto, a própria idéia de habitação pode ser interpretada e redefinida conforme o período histórico, social e cultural, o que acaba por influenciar no conceito de déficit habitacional ${ }^{1}$.

A nomenclatura de déficit habitacional, que induz erroneamente à expectativa de enfrentar a questão da moradia de forma setorial, deve ser entendida, segundo a Fundação João Pinheiro (2011), como a "noção mais imediata e intuitiva de necessidade de construção de novas moradias para a solução de problemas sociais e específicos de habitação, detectados em certo momento" e engloba tanto as moradias sem condições de serem habitadas devido à precariedade das construções ou pelo desgaste da estrutura física que devem ser repostas, quanto à necessidade de aumento de unidades habitacionais, decorrente da coabitação familiar, da dificuldade dos moradores de baixa renda em pagar aluguel ou da moradia em locais destinados a fins não residenciais.

Assim, este trabalho considera o termo 'habitação', diferente de 'casa ou 'moradia', imprimindo um sentido mais abrangente, pois não se restringe à construção física do imóvel, mas envolve a localização, a inserção na comunidade e o acesso aos serviços disponíveis, ou seja, considera tanto a unidade habitacional quanto seu entorno.

Uma habitação adequada deve possuir acesso às redes de água e esgoto, saneamento, acessibilidade ao trabalho e outros equipamentos básicos, não deve ser uma improvisada, como prédios em construção, viadutos e pontes; não deve ser precária como casas de taipa não revestida ou de madeira aproveitada, casas cobertas de palha ou sapé ${ }^{2}$; e não deve ser ocupada por mais de uma família.

Dessa forma, a falta da casa própria não deve ser confundida com a definição de déficit habitacional porque a propriedade do imóvel não garante a qualidade do mesmo, tampouco a provisão da infra-estrutura adequada.

Além disso, para elaborar programas habitacionais brasileiros, é essencial analisar os fatores demográficos e a dinâmica socioeconômica que condicionam a formação de famílias e as necessidades de moradias.

\footnotetext{
${ }^{1}$ Esse estudo optou por utilizar a metodologia desenvolvida pela Fundação João Pinheiro (FJP) por ser a mais tradicional. Seu primeiro estudo foi realizado em 1995, com base nos dados do Censo Demográfico de 1991. Desde então, vem sendo aprimorada e atualizada. Para a pesquisa, foi utilizado o estudo mais recente elaborado pela FJP em 2011com dados de 2007 reponderados.

${ }^{2}$ A Fundação João Pinheiro (2011), esclarece que telhados de sapê e similares podem ser considerados uma alternativa em áreas rurais restritas das regiões Norte e Nordeste do país.
} 
Segundo a apresentação da Fiesp para o 9o Congresso Brasileiro de Construção (2010), as necessidades de moradias decorrem, principalmente, da dinâmica familiar, ou seja, do processo de formação de novas famílias, influenciado pelo crescimento demográfico e pela evolução econômica da população. Essa seria a principal componente das necessidades habitacionais do Brasil, sendo influenciada pelo o crescimento demográfico e pela evolução da renda.

Assim, a falta de habitações adequadas agrava-se com o avanço do processo de urbanização e com o descompasso entre o crescimento da população urbana e a capacidade de instalação de infraestrutura necessária.

Portanto, para falar sobre políticas e programas habitacionais deve-se, primeiramente, entender o conceito de déficit habitacional.

O Ministério das Cidades estabelece dois diferentes tipos de déficit habitacional:

- O déficit habitacional quantitativo, composto pelas famílias que vivem em domicílios rústicos ou improvisados, têm que dividir suas casas com outras famílias, ou gastam excessivamente com aluguel.

- E o chamado déficit habitacional qualitativo, que caracteriza a necessidade de execução de melhorias em infra-estrutura, regularização fundiária, ampliação da moradia ou construção de banheiro.

Lannoy (2006) afirma que a carência de moradias constitui um grave problema dos governos brasileiros desde o início do século $\mathrm{XX}$, sendo ainda mais crítico entre as camadas de renda mais baixa da população.

Segundo o IBGE, os dados censitários sobre habitação passaram a ser publicados regularmente a partir de 1963 informando a respeito dos domicílios ocupados segundo as regiões físico-geográficas e as Unidades da Federação. Os levantamentos realizados em 1963 pelo Anuário Estatístico do Brasil (AEB), expostos por Lannoy (2006), mostram que o déficit habitacional brasileiro não é um problema recente. O Censo realizado em 1960 apresentava cerca de 13,5 milhões de domicílios ocupados no Brasil e uma população total de 71 milhões de habitantes. Na época estimava-se que, em média, uma família era composta por cinco pessoas, que, multiplicadas pelas 13,5 milhões de residências recenseadas, resultaria em 67,5 milhões de habitantes. Portanto, pode se estimar que o déficit habitacional quantitativo da época era próximo de 700 mil unidades habitacionais, número necessário para abrigar 3,5 milhões de pessoas. 
Em 1966 o Censo passou a informar também a situação dos domicílios (urbano e suburbano/ rural), a condição de ocupação (próprio / alugado e outros), e as instalações existentes (água encanada, iluminação elétrica e instalação sanitária) (LANNOY, 2006).

Essa inconstância nos dados a serem levantados gerou diferentes estimativas a respeito do déficit habitacional, sendo impossível identificar os números oficiais até 1995, quando a Fundação João Pinheiro (FJP) elaborou um estudo para a Secretaria Especial de Desenvolvimento Urbano (SEDU), atual Ministério das Cidades, com o objetivo de caracterizar a situação habitacional no país.

Uma constatação importante apontada nos estudos da FJP está no fato de que a classificação das famílias brasileiras por faixa de renda (de 0 a 3, de 3 a 5 ou de 5 a 10 salários mínimos) não leva em consideração a existência de diferenças regionais no país, onde há regiões nas quais as famílias mais pobres (na faixa de 0 a 3 salários mínimos) têm necessidades diferentes das famílias situadas na mesma faixa de renda, mas moradoras de outras regiões.

Por exemplo, as famílias pobres do sertão nordestino têm necessidades diferentes daquelas localizadas nas grandes cidades. E isso traz implicações importantes para os capítulos seguintes.

O estudo realizado pela Fundação João Pinheiro - FJP em 2011, orientado pela metodologia elaborada pela fundação, engloba tanto o déficit habitacional quantitativo (por incremento ou reposição do estoque de moradias) como o déficit por inadequação (deficiências na qualidade de vida de seus moradores, como infraestrutura inadequada).

O déficit por reposição de estoque inclui as moradias sem condições de serem habitadas em razão da precariedade das construções ou do desgaste da estrutura física; já o déficit por incremento de estoque considera a coabitação familiar forçada (famílias que pretendem constituir um domicilio unifamiliar), os moradores de baixa renda com dificuldade de pagar aluguel, os que vivem em casas e apartamentos alugados com grande densidade e os que vivem em imóveis e locais com fins não residenciais. A inadequação de domicílios considera a inadequação fundiária, carência de infraestrutura, ausência de banheiro de uso exclusivo, cobertura inadequada e adensamento excessivo dos domicílios próprios (FJP, 2011).

O estudo mais recente, publicado em 2011, com dados de 2008, apresenta um déficit habitacional de 5,5 milhões de domicílios, sendo que 1,6 milhões estão localizados nas principais regiões metropolitanas do País, o que representa $27 \%$ da carência habitacional (TABELA 1). 
TABELA 1: DÉFICIT HABITACIONAL BRASILEIRO EM 2008

\begin{tabular}{|l|r|r|r|}
\hline \multirow{2}{*}{ Especificação } & \multicolumn{3}{|c|}{ Déficit Habitacional Valores } \\
\cline { 2 - 4 } & \multicolumn{3}{|c|}{ Absolutos } \\
\hline Norte & 555.130 & \multicolumn{1}{c|}{ Urbano } & \multicolumn{1}{c|}{ Rural } \\
\hline Nordeste & 1.946 .735 & 1.305 .628 & 641.107 \\
\hline Sudeste & 2.046 .312 & 1.969 .424 & 76.888 \\
\hline Sul & 580.893 & 519.080 & 61.813 \\
\hline Centro-Oeste & 417.240 & 387.628 & 29.612 \\
\hline Brasil & $\mathbf{5 . 5 4 6 . 3 1 0}$ & $\mathbf{4 . 6 2 9 . 8 3 2}$ & $\mathbf{9 1 6 . 4 7 8}$ \\
\hline & & & \\
Total RMs & 1.537 .030 & 1.516 .322 & 916.478 \\
\hline Demais Áreas & 4.009 .280 & 3.113 .510 & 895.770 \\
\hline
\end{tabular}

Fonte: Instituto Brasileiro de Geografia e Estatística (IBGE), Pesquisa Nacional por Amostra de Domicílios (Pnad), 2008. Adaptado de Fundação João Pinheiro, 2011.

Nas áreas urbanas (TABELA 2) há aumento do déficit habitacional de 2000 a 2006 e declínio até 2008. Nas regiões metropolitanas houve importante ascensão entre 2000 e 2005 e, a partir de 2005 a tendência foi de queda até 2008.

Com base nos dados da Pesquisa Nacional de Amostra Domiciliar (Pnad), de 2008, a FGV constatou que nesse período o número de novas residências passou a ser maior que o de novas famílias, justamente as que demandam novas habitações. Isto se explica pela melhora de renda dos trabalhadores e maior acesso aos imóveis.

TABELA 2: EVOLUÇÃO DO DÉFICIT HABITACIONAL URBANO NO BRASIL ENTRE 2000 E 2008.

\begin{tabular}{|l|r|r|r|r|r|}
\hline \multirow{2}{*}{ Especificação } & \multicolumn{5}{|c|}{ Déficit Habitacional Urbano } \\
& 2000 & 2005 & 2006 & 2007 & 2008 \\
\hline Brasil & $\mathbf{5 . 8 7 5 . 4 2 6}$ & $\mathbf{6 . 3 0 7 . 2 5 3}$ & $\mathbf{6 . 2 6 2 . 2 0 3}$ & $\mathbf{5 . 9 8 9 . 0 6 4}$ & $\mathbf{5 . 5 4 6 . 3 1 0}$ \\
\hline Total RMs & 1.413 .509 & 1.856 .762 & 1.813 .143 & 1.785 .452 & 1.537 .030 \\
\hline Demais Áreas & 4.461 .917 & 4.450 .491 & 4.449 .060 & 4.203 .612 & 4.009 .280 \\
\hline
\end{tabular}

Fonte: Instituto Brasileiro de Geografia e Estatística (IBGE), Pesquisa Nacional por Amostra de Domicílios (Pnad), 2008. Adaptado de Fundação João Pinheiro, 2011.

A análise segundo faixas de rendimento médio familiar mensal mostra que as famílias que residem em domicilio precário estão concentradas nas faixas de mais baixa renda. $O$ déficit está 
concentrado na faixa de até 3 (três) salários mínimos $(89,2 \%)$ e na de três a cinco salários mínimos (7\%). (GRAFICO 1).

\section{GRÁFICO 1: DÉFICIT HABITACIONAL URBANO POR FAIXAS DE RENDA MÉDIA FAMILIAR MENSAL, EM SALÁRIOS MÍNIMOS (\$M) - BRASIL - 2008}

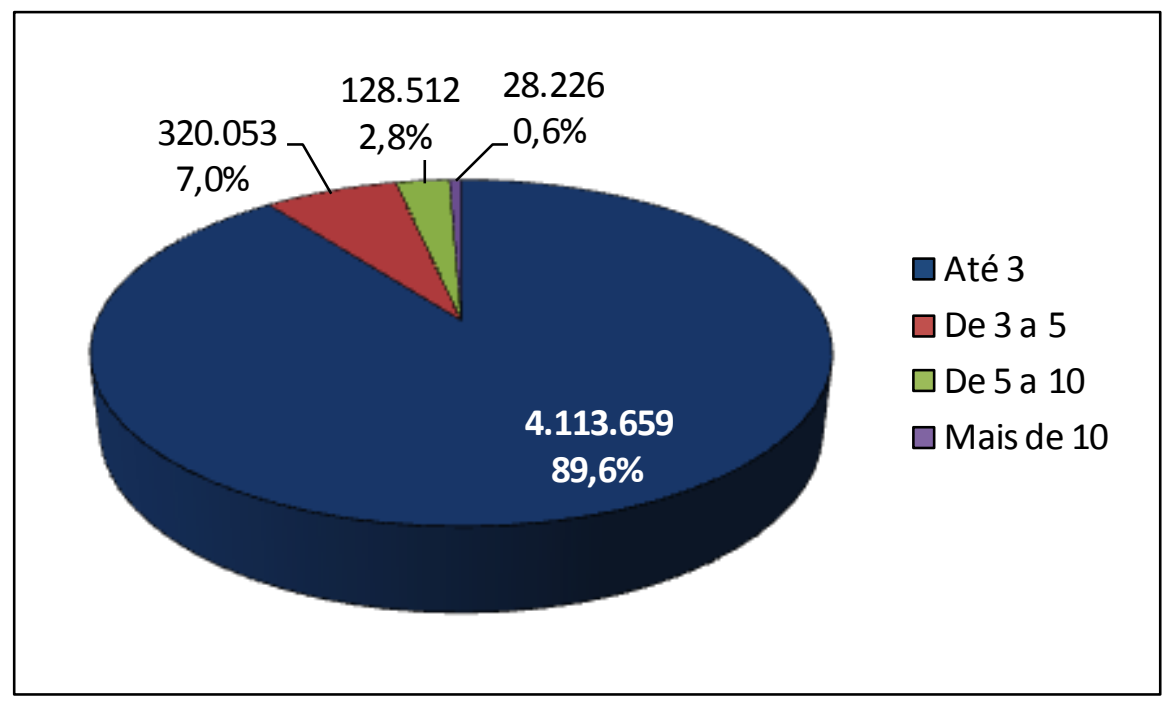

Fonte: Instituto Brasileiro de Geografia e Estatística (IBGE), Pesquisa Nacional por Amostra de Domicílios (Pnad) - 2008. Adaptado de Fundação João Pinheiro, 2011.

A Região Sudeste, a mais populosa do Brasil, concentra 36,9\% do total do deficit habitacional do País, ou 2,046 milhões de moradias, seguida pela Região Nordeste, com o segundo maior deficit: 1,946 milhão de domicílios, ou $35,1 \%$ do total. Comparada às demais regiões, a Região Norte apresenta o maior percentual em termos relativos - o deficit de 555 mil unidades habitacionais corresponde a 13,9\% dos domicílios da região. (GRÁfICO 2) .

Além do déficit atual, a política habitacional brasileira deve ter como meta a produção de moradias para as famílias que irão se formar nos próximos anos, atendendo às necessidades habitacionais atuais e futuras, reduzindo-o a um padrão aceitável. Assim, deve-se considerar o aumento da demanda por habitações, consequência do aumento da população brasileira e da mudança na distribuição da faixa etária.

De acordo com os dados apresentados pela Fiesp no 9 Congresso Brasileiro de Construção ConstruBusiness 2010, em 12 anos, a população brasileira cresceu a uma taxa média de 1,3\% ao ano, passando de 166 milhões em 1998 para mais de 193 milhões em 2010. 


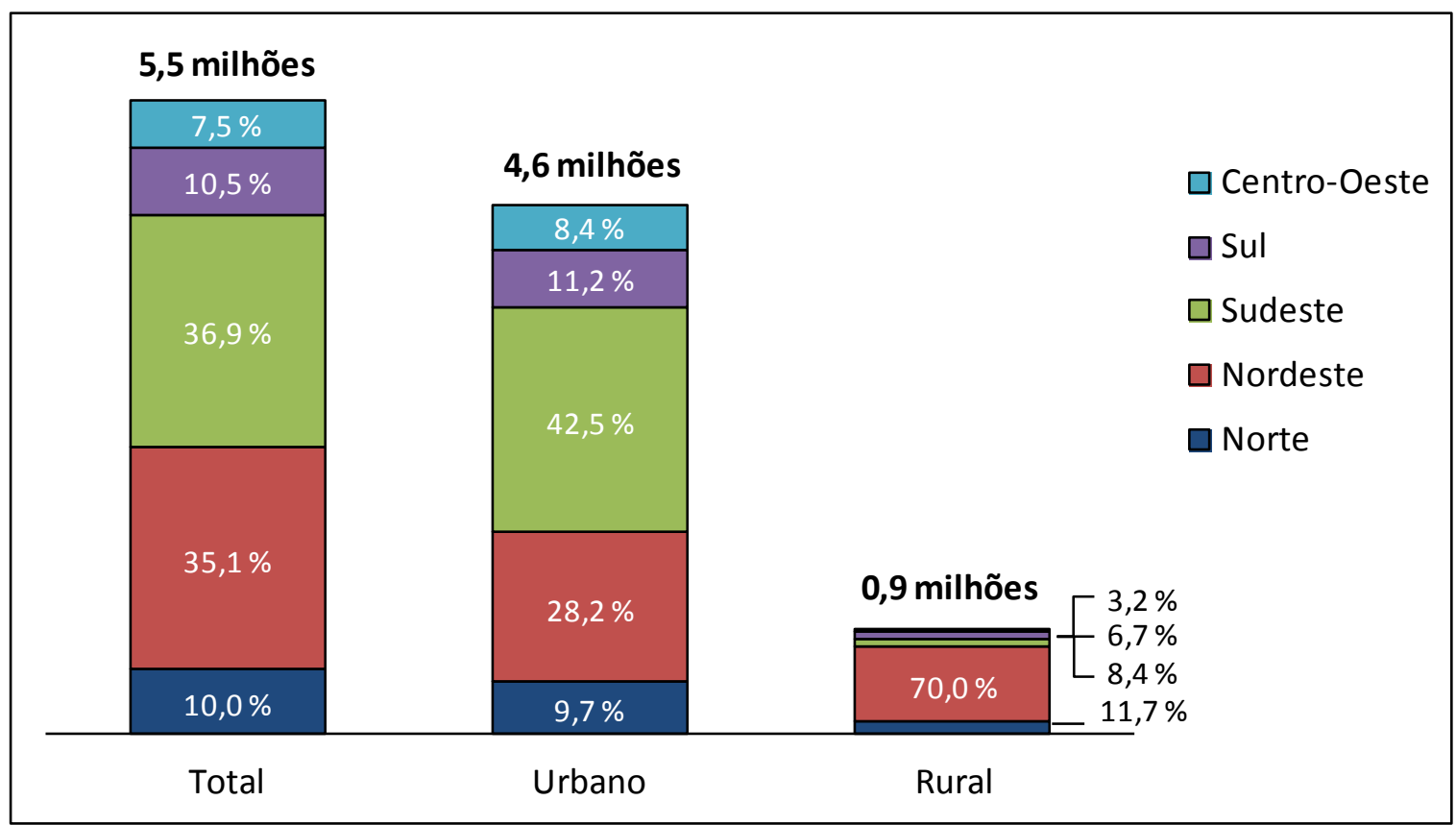

Fonte: Instituto Brasileiro de Geografia e Estatística (IBGE), Pesquisa Nacional por Amostra de Domicílios (Pnad) - 2008. Adaptado de Fundação João Pinheiro, 2011.

A expectativa para 2022 é a de que essa taxa diminua, chegando a 0,5\% ao ano. Dessa forma, a população atingirá 209 milhões em 2022, com uma taxa média de expansão demográfica de 0,6\% ao ano. Essa diminuição do ritmo de crescimento está associada ao aumento da renda e à queda da taxa de fecundidade. O Gráfico 3 traz a trajetória da população brasileira no período de 2010 a 2022, por região geográfica.

Estima-se também que a distribuição da população brasileira por faixa etária mude bastante até 2022. De acordo com a Tabela 3, haverá uma forte expansão do número de famílias entre 2010 e 2022. A taxa de crescimento do número de famílias, de 1,88\% ao ano, é quase três vezes o ritmo de expansão demográfica. Com isso, as famílias devem passar de 63,6 milhões para 79,6milhões, com a formação de 1,33 milhão de novas famílias por ano.

Dessa forma, o ritmo de crescimento demográfico e a trajetória econômica do país levam à formação de, em média, 1,326 milhão de novas famílias por ano entre 2010 e 2022. Além disso, para eliminar as moradias precárias, estimadas em 3,627 milhões em 2009, a Fiesp afirma no 9o Construbusiness (2010), ser necessário construir 279 mil moradias por ano até 2022. Some-se a essa quantia, a construção de mais 203 mil habitações por ano para eliminar a coabitação indesejada até 2022. 
GRÁFICO 3: CRESCIMENTO DA POPULAÇÃO BRASILEIRA ENTRE 2010 E 2022.

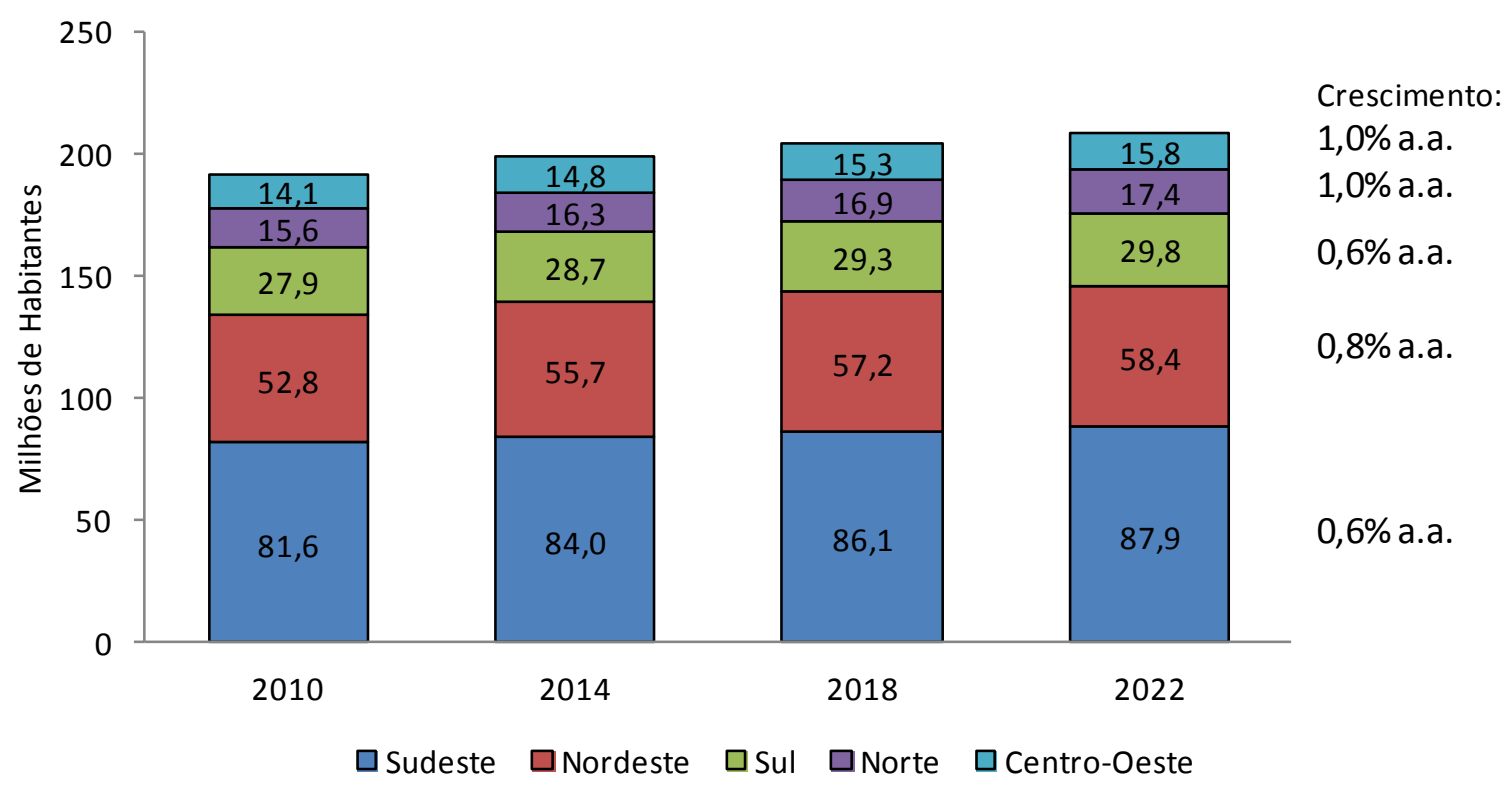

Fonte: Instituto Brasileiro de Geografi a e Estatística (IBGE). Adaptado de FIESP: Caderno Técnico Construbusiness 2010

TABELA 3: FAMÍLIA POR FAIXA ETÁRIA DO CHEFE - BRASIL

\begin{tabular}{|c|r|r|r|r|c|}
\hline Faixa etária & \multicolumn{1}{|c|}{2010} & \multicolumn{1}{c|}{2014} & \multicolumn{1}{c|}{2018} & \multicolumn{1}{c|}{2022} & (\%) ao ano \\
\hline $13-18$ & 372.881 & 384.199 & 385.715 & 358.727 & $-0,32 \%$ \\
\hline $19-25$ & 4.867 .443 & 4.663 .209 & 4.685 .762 & 4.822 .759 & $-0,08 \%$ \\
\hline $26-35$ & 14.028 .254 & 14.826 .097 & 14.726 .879 & 14.247 .737 & $0,13 \%$ \\
\hline $36-45$ & 14.623 .904 & 15.298 .703 & 16.567 .884 & 17.965 .428 & $1,73 \%$ \\
\hline $46-55$ & 12.941 .619 & 14.360 .689 & 15.208 .243 & 15.816 .203 & $1,69 \%$ \\
\hline $56-65$ & 8.532 .123 & 10.043 .109 & 11.796 .838 & 13.489 .557 & $3,89 \%$ \\
\hline $66-75$ & 5.293 .098 & 5.956 .787 & 6.922 .729 & 8.235 .719 & $3,75 \%$ \\
\hline mais de 75 & 2.974 .717 & 3.500 .445 & 4.052 .750 & 4.650 .289 & $3,79 \%$ \\
\hline Total & $\mathbf{6 3 . 6 3 4 . 0 3 8}$ & $\mathbf{6 9 . 0 3 3 . 2 3 8}$ & $\mathbf{7 4 . 3 4 6 . 8 0 0}$ & $\mathbf{7 9 . 5 8 6 . 4 1 9}$ & $\mathbf{1 , 8 8 \%}$ \\
\hline
\end{tabular}

Fonte: Fundação Getúlio Vargas (FGV).

Adaptado de FIESP: Caderno Técnico Construbusiness 2010

Para atender às novas famílias, eliminar a precariedade e reduzir a coabitação é necessário produzir cerca de 1,8 milhão de moradias por ano. Isso significa que será necessário construir 23,5 milhões de moradias entre 2010 e 2022 (TABELA 4), o que equivale ao total de moradias dos três Estados mais populosos do país em 2009: São Paulo, Minas Gerais e Rio de Janeiro. 
Multiplicando a quantidade necessária de habitações pelo investimento a ser feito, a construção das novas moradias deve mobilizar cerca de $\mathrm{R} \$ 204$ bilhões por ano no período. Cabe relatar que, segundo entrevista realizada em dezembro de 2011 com Carlos Eduardo Gomes, do Departamento de Produção Habitacional do Ministério das Cidades, o investimento em novas habitações desde a criação do PMCMV até dezembro de 2011, foi de $\mathrm{R} \$ 82,5$ bilhões, sendo que $\mathrm{R} \$ 29,3$ bilhões correspondem já a fase 2 do PMCMV.

TABELA 4: NECESSIDADES DE NOVAS MORADIAS - 2010 A 2022

\begin{tabular}{|c|c|c|c|c|}
\hline \multicolumn{5}{|c|}{ Novas Moradias } \\
\hline Ano & $\begin{array}{c}\text { Para atender às } \\
\text { novas famílias }\end{array}$ & $\begin{array}{c}\text { Para eliminar a } \\
\text { precariedade }\end{array}$ & $\begin{array}{c}\text { Para reduzir a } \\
\text { coabitação }\end{array}$ & Total \\
\hline 2010 & 1.281 .560 & 120.000 & 120.000 & 1.521 .560 \\
\hline 2011 & 1.307 .920 & 220.000 & 170.000 & 1.697 .920 \\
\hline 2012 & 1.334 .822 & 220.000 & 170.000 & 1.724 .822 \\
\hline 2013 & 1.362 .277 & 220.000 & 170.000 & 1.752 .277 \\
\hline 2014 & 1.390 .298 & 220.000 & 170.000 & 1.780 .298 \\
\hline 2015 & 1.290 .754 & 280.000 & 200.000 & 1.770 .754 \\
\hline 2016 & 1.314 .905 & 280.000 & 200.000 & 1.794 .905 \\
\hline 2017 & 1.339 .509 & 280.000 & 200.000 & 1.819 .509 \\
\hline 2018 & 1.364 .572 & 280.000 & 200.000 & 1.844 .572 \\
\hline 2019 & 1.275 .726 & 376.821 & 260.000 & 1.912 .547 \\
\hline 2020 & 1.297 .632 & 376.821 & 260.000 & 1.934 .453 \\
\hline 2.021 & 1.319 .914 & 376.821 & 260.000 & 1.956 .735 \\
\hline 2.022 & 1.342 .579 & 376.821 & 260.000 & 1.979 .400 \\
\hline Total & $\mathbf{1 7 . 2 2 2 . 4 6 9}$ & $\mathbf{3 . 6 2 7 . 2 8 4}$ & $\mathbf{2 . 6 4 0 . 0 0 0}$ & $\mathbf{2 3 . 4 8 9 . 7 5 3}$ \\
\hline
\end{tabular}

Fonte: Fundação Getúlio Vargas (FGV).

Adaptado de FIESP: Caderno Técnico Construbusiness 2010

Para os imóveis destinados a famílias com renda mensal de até 3 salários mínimos, o valor considerado como média nacional pelo Construbusiness 2010 foi de R\$ 50.000, sendo abaixo do necessário para a construção em regiões metropolitanas. Já para os imóveis destinados a famílias com renda mensal entre 3 e 10 salários mínimos, o valor considerado foi de $\mathrm{R} \$ 85$ mil. Para os imóveis de padrão médio-alto foi considerada uma média de R\$ 250 mil.

Nas projeções, também é considerado o processo de valorização dos imóveis, devido ao aumento do investimento imobiliário e do crescimento da renda das famílias, que faz a média passar de R\$ 86,2 mil em 2010 para R\$ 152,7 mil em 2022. A mobilidade social também possibilitará redução no número de famílias com renda de até 3 salários mínimos de 24,8 milhões em 2010 para 20,7 milhões em 2022. 
Contrapondo-se ao déficit habitacional, existe uma grande quantidade de imóveis vazios, decorrente de um processo de ocupação do solo urbano que levou ao esvaziamento dos centros tradicionais, e que foram perdendo população e atividades. De acordo com a Pnad 2008, o Brasil possui 7,542 milhões de imóveis vagos, onde $72 \%$ estão localizados em áreas urbanas e $28 \%$ em áreas rurais. Desses, 6,307 milhões estão em condições de serem ocupados, 894 mil estão em construção ou reforma e 340 mil, em ruínas.

A tabela 5 apresenta os domicílios vagos (urbanos e rurais) com potencial para serem habitados. São 7,202 milhões de unidades, 72,7\% em áreas urbanas e $27,3 \%$ em áreas rurais. Desses domicílios, 3,078 milhões, encontram-se na região Sudeste e 1,337 milhão em São Paulo. Esses dados representam $3 \%$ a mais que o déficit habitacional, superando o déficit na maioria do País.

Os imóveis vagos e depreciados localizam-se em locais urbanizados e com acesso à infraestrutura, em geral nas áreas centrais e consolidadas das maiores cidades (BONDUKI, 2008). Essa estatística revela não só a má distribuição das moradias, mas também o baixo poder aquisitivo dos pobres no acesso ao estoque habitacional adequado.

TABELA 5: DOMICÍLIOS VAGOS COM POTENCIAL PARA SEREM HABITADOS EM 2008.

\begin{tabular}{|l|r|r|r|}
\hline \multirow{2}{*}{ Especificação } & \multicolumn{3}{|c|}{ Domicílios Vagos } \\
\cline { 2 - 4 } & \multicolumn{1}{|c|}{ Total } & \multicolumn{1}{c|}{ Urbano } & \multicolumn{1}{l|}{ Rural } \\
\hline Norte & 506.158 & 356.410 & 149.748 \\
\hline Nordeste & 2.091 .877 & 1.242 .191 & 849.686 \\
\hline Sudeste & 3.078 .854 & 2.527 .983 & 550871 \\
\hline Sul & 973.231 & 698.045 & 275.186 \\
\hline Centro-Oeste & 551.918 & 410.011 & 141.907 \\
\hline Brasil & $\mathbf{7 . 2 0 2 . 0 3 8}$ & $\mathbf{5 . 2 3 4 . 6 4 0}$ & 1.967 .398 \\
\hline Total RMs & 1.902 .334 & 1.834 .287 & 68.047 \\
\hline Demais Áreas & 5.299 .704 & 3.400 .353 & 1.899 .351 \\
\hline
\end{tabular}

Fonte: Instituto Brasileiro de Geografia e Estatística (IBGE), Pesquisa Nacional por Amostra de Domicílios (Pnad) - 2008. Adaptado de Fundação João Pinheiro, 2011.

Segundo a FJP (2011), a ausência de serviços de infra-estrutura urbana e saneamento ambiental, como eletricidade, abastecimento de água com canalização interna, rede de esgotamento sanitário ou fossa séptica e coleta de lixo regular pelo menos duas vezes por semana, é o maior problema entre os critérios de inadequação de domicílios e continua sendo um desafio a ser enfrentado pelos órgãos 
responsáveis. Em 2008, cerca de 10,948 milhões de domicílios eram carentes de pelo menos um serviço de infraestrutura, o correspondente a $22,3 \%$ dos domicílios particulares permanentes urbanos do país, sem considerar os domicílios inseridos no cálculo do déficit habitacional, sendo cerca de $60 \%$ concentrados nas faixas de renda de até três salários mínimos (GRAFICO 4).

Observa-se que a carência de infraestrutura é relativamente menor nas regiões metropolitanas, que têm $13,6 \%$ de seus domicílios nessa situação, ao passo que nas demais áreas o percentual chega a $27,0 \%$ dos domicílios.

Mais de 5,5 milhões de moradias precisam ser construídas em todo o País somente para acabar com o deficit habitacional atual. Infelizmente, o déficit habitacional ainda é visto como um problema numérico a ser superado pela provisão em massa de unidades habitacionais genéricas. Ao mesmo tempo, a população de renda mais baixa, que representa parcela significativa do déficit, ainda não conseguiu ter suas necessidades habitacionais favoravelmente supridas pelas políticas e programas implementados ao longo de todos esses anos.

\section{GRÁFICO 4: DOMICÍLIOS COM CARÊNCIA DE INFRAESTRUTURA.}

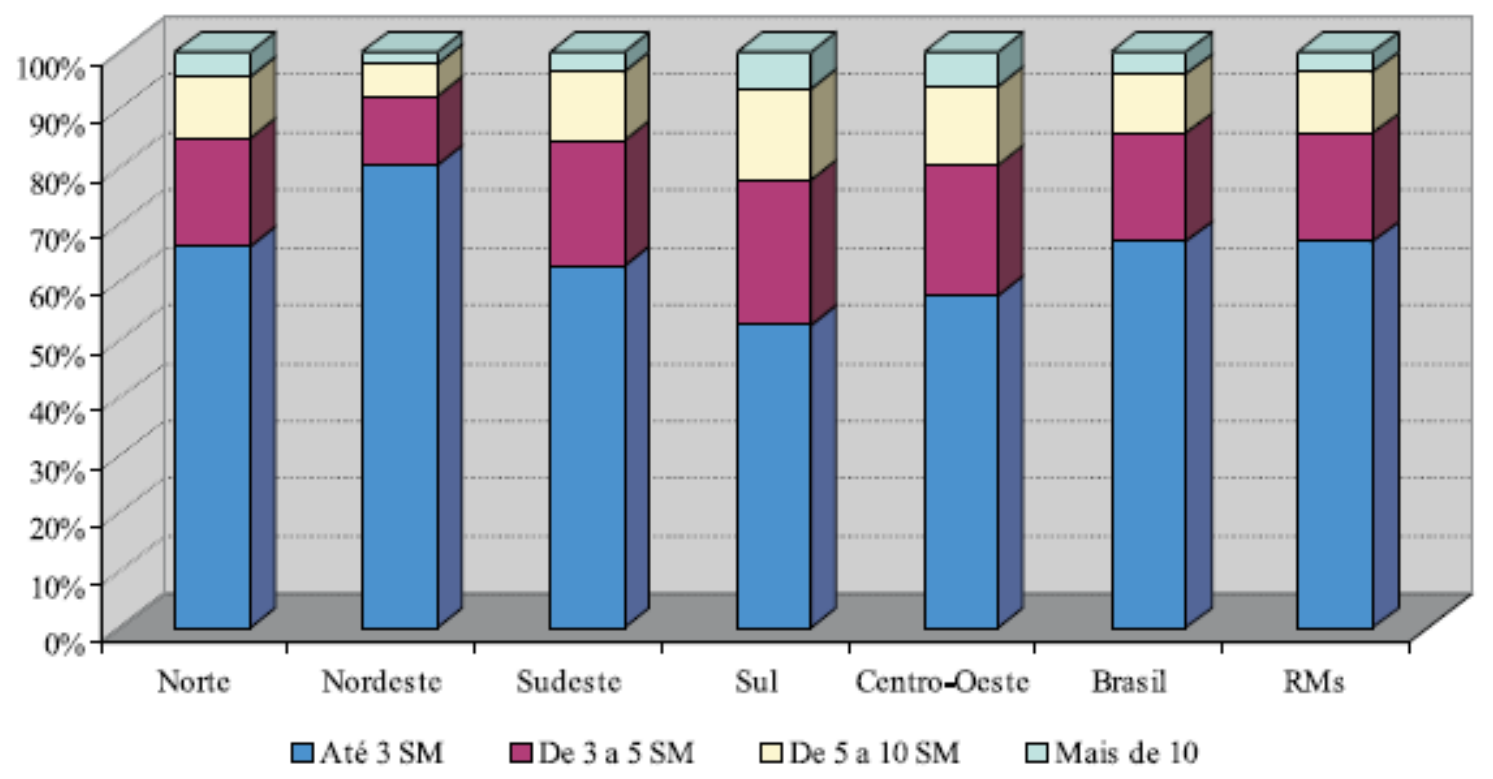

Fonte: Instituto Brasileiro de Geografi a e Estatística (IBGE), Pesquisa Nacional por Amostra de Domicílios (Pnad), 2008. Elaborado por: Fundação João Pinheiro, 2011.

E é nesse contexto que, em 2009, foi lançado o programa Minha Casa, Minha Vida, que pretende construir ou reformar três milhões de moradias até 2014 para famílias com renda mensal de até dez salários mínimos (CAIXA, 2010). 


\section{POLÍTICAS, PLANOS E PROGRAMAS HABITACIONAIS}

Este capítulo tem como objetivo apresentar os resultados da experiência de política habitacional brasileira antes de 2009, quando foi lançado o Programa Minha Casa Minha Vida, objeto de estudo dessa pesquisa.

As experiências anteriores são importantes para contextualização e análise do PMCMV, pois a política habitacional atual busca, em parte, se contrapor à lógica da política antecedente. Ao mesmo tempo, várias características das políticas anteriores, principalmente referentes às fontes de financiamento, continuam presentes até os dias atuais.

Tais considerações se fazem pertinentes porque auxiliarão a compreender o atual estágio da política habitacional, no que diz respeito ao cumprimento dos requisitos legais para garantir o acesso ao direito à moradia.

\section{4 - Fundação da Casa Popular}

No Brasil, no início do século XX, as políticas de saneamento desenvolvidas pelo Estado reduziram a mortalidade, favorecendo ainda mais o crescimento populacional das cidades e provocando o aumento da demanda por habitação. Esse fato se intensificou com as migrações do meio rural para as cidades a partir de 1950, devido ao processo de industrialização.

Em 1946, de acordo com Carmo (2006) ocorreu a primeira experiência relevante de intervenção do Estado diretamente na área habitacional: a Fundação da Casa Popular (FCP), um órgão específico para tratar dos problemas habitacionais e que, por sua vez, lançaria as bases para criação do BNH, quase duas décadas depois.

Amparada pelo Decreto-Lei 9.218 , de 1 o de maio de 1946, foi a primeira instituição de âmbito nacional, direcionada especificamente para a provisão de residências para as classes de baixa renda.

As edificações da Fundação da Casa Popular estavam localizadas em grandes centros urbanos, em sintonia com as necessidades habitacionais do país. Entretanto, a maioria dos conjuntos habitacionais localizava-se em cidades de pequeno e médio porte, objetivando atender ao maior número possível de municípios visando obter mais vantagens políticas. Prática comum à época, conforme demonstrado por Carmo (2006).

A FCP foi criada para amenizar os problemas habitacionais da população de baixa renda, porém passou a ter outras atribuições complementares como o financiamento de obras urbanísticas, de abastecimento de água, esgotos, energia elétrica e assistência social. Naquele momento a questão 
habitacional era tratada como algo que ia além da simples produção de unidades habitacionais (AZEVEDO e ANDRADE, 1982, apud CARMO, 2006).

Nessa época também já se procurava viabilizar a parceria entre os entes federativos, cabendo aos municípios a doação do terreno, realização de obras de infra-estrutura, água, luz e esgoto. Apesar do esforço intergovernamental, o acesso à casa própria era, na prática, limitado. As restrições de informação, de prazo, e de unidades oferecidas reduziram drasticamente as possibilidades de amplo atendimento.

Para viabilizar a produção de moradias, o financiamento ocorreria através da cobrança de contribuição obrigatória de $1 \%$ sobre as transações imobiliárias, por parte dos governos estaduais que deveriam repassá-los à União. Na prática, ou os governos locais não recolhiam tal contribuição ou simplesmente não a repassavam. Desta forma, os recursos que financiaram as atividades da FCP tiveram origem orçamentária e foram declinando com o passar dos anos.

No início dos anos 1960, com o fim do período populista, a Fundação da Casa Popular foi extinta, produzindo no total menos de 17 mil unidades ao longo de seus dezoito anos.

Diante das dificuldades em operacionalizar os financiamentos previstos nessa iniciativa, o governo criou o Sistema Financeiro de Habitação (SFH) e o Banco Nacional da Habitação (BNH) pela Lei $\mathrm{n}^{\circ} .4380$, de 1964, durante o regime militar.

\section{4-1986 - Banco Nacional de Habitação}

O BNH foi o principal órgão da política habitacional do período, visto que tinha o objetivo de ser o órgão orientador, disciplinador e controlador de todo o sistema, estimulando a formação de poupança e sua canalização para o SFH e orientando o acesso das sociedades de crédito imobiliário ao mercado nacional de capitais (CARMO, 2006). Coube ainda ao BNH atuação no financiamento, na elaboração e execução de projeto habitacional.

Às vésperas da criação do $\mathrm{BNH}$, dois movimentos da produção habitacional se firmaram: a verticalização, legislada pelo Estado, e a periferização, preterida pelo Estado. O primeiro, vinculado às empresas de construção e aos incorporadores imobiliários, com a produção planejada da moradia mínima, econômica e higiênica como solução técnica moderna; o segundo, conduzido pela ação dos trabalhadores despejados do mercado formal e dos migrantes, em loteamentos periféricos sem infraestrutura urbana ou em terrenos clandestinos, com a autoconstrução (NASCIMENTO e BRAGA, 2009).

Sustentado pelo entendimento das favelas como uma doença urbana que precisa ser exterminada e pela pressão das classes dominantes preocupadas com a marginalidade, o BNH foi criado 
com o objetivo de estimular a construção de habitações de interesse social e o financiamento da casa própria, principalmente pelas classes de baixa renda

Segundo Fernandes e Silveira (2010) a criação do BNH foi uma tentativa de legitimação do governo militar para buscar apoio popular. Bonduki (2008) reforça que o BNH foi uma resposta desse governo à intensa crise de moradia presente num país que se urbanizava aceleradamente.

Financeiramente, foram criadas duas fontes de financiamento: o Fundo de Garantia por Tempo de Serviço (FGTS) (Lei 5.107, de setembro de 1966) - uma poupança compulsória descontada em folha de pagamento e recolhida pelo Estado, que buscaria dar suporte às camadas da população de menor renda; e o Sistema Brasileiro de Poupança e Empréstimo (SBPE), mecanismo de poupança voluntária, captada pelo mercado financeiro privado, que serviria às demandas das faixas de classe média e alta.

O mercado habitacional foi dividido em três segmentos: o mercado popular, para famílias com renda de um a três salários mínimos; o mercado econômico, focado nas camadas com renda familiar entre três e seis salários mínimos; e o mercado médio, para famílias acima de seis salários mínimos. Para as famílias de baixa renda, o financiamento e a promoção da produção se dariam pelo poder público. Já para as famílias com renda superior, o financiamento seria encargo do setor privado, suportado pelos fundos carreados para as cadernetas de poupança.

Apesar da criação de instituições financeiras para garantir a autonomia do BNH, houve um elevado grau de inadimplência, principalmente na população de baixa renda, devido à política econômica recessiva dos primeiros anos da ditadura.

Com as quedas verificadas nos salários da população, a parcela do financiamento habitacional foi ocupando cada vez maior participação na renda do trabalhador. Logo, a tentativa de atender as famílias com até três salários mínimos foi frustrada.

Esse modelo de política habitacional visava atender a demanda habitacional de forma abrangente e contemplava, principalmente, os interesses imobiliários da construção civil e das grandes empreiteiras.

“Foi enfatizada a produção de casas para a venda, estimulando a indústria da construção civil e assim aumentando a oferta de empregos com baixa qualificação para se amenizar os possíveis efeitos que o controle da inflação, naquele período, pudessem provocar. A questão da moradia mudaria de foco, tendo a provisão de empregos como meta e a produção de moradia como meio que forneceria um subproduto politicamente desejável."(TASCHNER, 1997)

Foram implantados projetos padronizados, geralmente em terrenos inadequados em localizações periféricas, sem levar em conta especificidades locais ou regionais (MALERONKA, 2005). 
Assim, logo nos primeiros anos, o Plano Nacional de Habitação sofreu pesadas críticas, como por parte do IAB, que afirmava ser inaceitável continuar a construir casas isoladas, sem acesso à infraestrutura (NASCIMENTO e BRAGA, 2009).

Entre 1964 e 1986 o BNH produziu em torno de 4,5 milhões de habitações, uma média de 204.000 unidades por ano, ou seja, 27\% do incremento total de estoque ocorrido entre 1960 e 1985. (FERNANDES e SILVEIRA, 2010).

Porém, do total das unidades construídas pelo órgão, apenas 33,5\% foram destinadas ao setor popular, tendo pouco impacto junto às camadas mais pobres da população. Destaca-se ainda que, durante 1970 até o início dos anos 1980, o BNH não esteve voltado aos segmentos populares, sendo apenas $6,4 \%$ do financiamento destinado a famílias com renda inferior a 3,5 salários mínimos. Dessa forma, é possível perceber que o BNH privilegiou interesses econômicos em detrimento aos sociais.

Em 22 anos de BNH, 92\% dos recursos do Sistema Financeiro da Habitação (SFH) foram aplicados em benefício de famílias com rendimento superior a cinco salários mínimos, enquanto $80 \%$ da população brasileira ganhavam menos que isso. (NASCIMENTO e BRAGA, 2009).

Logo, a habitação popular, denominada assim a partir do BNH, tornou-se sinônimo do que havia de mais deplorável em termos de arquitetura e urbanismo: padronização de projetos, grandes conjuntos na periferia; execução precária; ausência de participação do usuário; financiamento inacessível às classes com renda mais baixa.

A crise do SFH agravou-se em 1983 e o BNH acabou por ser extinto em 1986 pelo Decreto-Lei № 2.291/86 que também reestruturou o SFH, distribuindo as atribuições do banco entre o Ministério de Desenvolvimento Urbano e Meio Ambiente - MDU, o Conselho Monetário Nacional - CMN, o Banco Central do Brasil - Bacen, e a Caixa Econômica Federal - Caixa (VILLAÇA, 1986).

O BNH acabou transferindo suas operações, funções, patrimônio e estrutura administrativa para a Caixa Econômica Federal, sem qualquer modificação na maneira de se conduzir a política habitacional. Bonduki (2008) destaca que o BNH foi suprimido sem encontrar oposição, pois "havia se tornando uma das instituições mais odiadas do país".

Com a extinção do BNH, a crise institucional do setor se amplificou. A política habitacional, até meados dos anos 90, foi marcada, segundo Carmo (2006) por duas características: a fragmentação institucional e a descontinuidade, resultado da criação e extinção de vários órgãos públicos responsáveis pela política habitacional. 
Somente ao final da década de 80 , quando os movimentos sociais passaram a ser reconhecidos e a ter voz política, os benefícios da participação do usuário na produção da moradia começaram a ser reconhecidos.

\section{6-2009 - Política Nacional de Habitação}

Durante os governos Sarney (1985-1990) e Collor (1990-1992) estabeleceu-se um vácuo institucional na política habitacional (LANNOY, 2006). Esse setor, devido ao retardamento de recursos e clientelismo do governo, acabou como coadjuvante na elaboração das políticas públicas. Assim, os financiamentos da Caixa Econômica tiveram como característica a elitização dos beneficiários dos programas habitacionais.

Já no Governo Itamar Franco (1992-1994) não houve mudanças substanciais devido ao rombo estimado de 20 bilhões de dólares do SFH. (FERNANDES e SILVEIRA, 2010)

Resumidamente, como exposto, o modelo de política habitacional brasileiro, entre 1964 e 1995, pode ser caracterizado pela regressividade das fontes de financiamento, baixa efetividade, centralização das decisões, baixíssima participação popular e privatização do espaço público.

É no Governo Fernando Henrique (1995-1998 e 1999-2002) que se começa a pensar em novos modelos para a política habitacional. As reformas propostas para a área habitacional tinham como objetivo acabar com os entraves da política adotada no período anterior, havendo uma forte tentativa de refazer a estrutura institucional com maior capacidade para o setor.

Em 1996, constitui-se uma nova Política Nacional de Habitação (PNH), com um conjunto de medidas de intervenção pública, público-alvo definido e com metas e objetivos a serem alcançados.

A política habitacional do governo FHC esteve apoiada, segundo Carmo (2006), em cinco premissas.

1. Que a moradia não compreende simplesmente as edificações, mas também um conjunto de condições de que assegure condições ambientais apropriadas, espaço suficiente, segurança, iluminação, ventilação, acesso à infra-estrutura, como água e esgoto, e fácil acesso em relação ao emprego e aos equipamentos de serviços urbanos.

2. Que a provisão de moradias deve ser amparada por um sistema financeiro, objetivando o atendimento do maior número de famílias possível e a criação de mecanismos para a formação de poupanças, que devem ser canalizados para a produção de unidades habitacionais. 
3. Criação de mecanismos que estimulem a participação e a cidadania do cidadão, que deve participar da melhor alternativa de produção e de acesso à moradia. "Reconhecer seu lugar e reconhecer-se nele são requisitos para que o beneficiário do projeto adquira segurança como indivíduo e cidadão e passe a ter um melhor relacionamento com sua moradia e sua cidade".

4. Que o Estado evite o quanto possível a utilização especulativa da terra em prejuízo, principalmente das classes de menor renda.

5. Que a questão habitacional deva ser enfrentada como uma política de Estado, envolvendo todas as esferas de poder, e que não seja interrompida a cada mudança de governo.

Dessa forma, a concepção de habitação da PNH tem como premissa uma visão que vai muito além da idéia de habitação apenas como a unidade 'casa', englobando a garantia de moradia digna que contemple a inserção urbana, infraestrutura e equipamentos comunitários.

Assim, segundo a Caixa Econômica Federal (2005) apud Carmo (2006), a produção de moradias beneficiou mais de dez milhões de pessoas gerando, direta e indiretamente, mais de 3,05 milhões de empregos, entre 1995 e 2002.

Em 1999, ainda durante o Governo FHC foi criado o Programa de Arrendamento Residencial PAR -, programa voltado à produção de unidades novas para arrendamento com recursos formado pelo FGTS e de origem fiscal.

Porém, o gigantismo do Estado agravou a situação de desigualdade social aportando recursos para as classes sociais que menos dependiam dele. A falta de recursos financeiros teve como conseqüência a queda do número de beneficiários atendidos. Assim, como no BNH, as classes de renda maior foram as maiores beneficiarias com os financiamentos oriundos da Caixa Econômica Federal.

De acordo com Bonduki (2008) entre 1995 e 2003, 78,84\% do total dos recursos foram destinados a famílias com renda superior a 5 salários mínimos, sendo que apenas 8,47\% foram destinados para a baixíssima renda (até 3 SM) onde se concentravam $83,2 \%$ do déficit habitacional.

Tentar financiar os segmentos populacionais mais pobres com recursos que requerem retorno financeiro novamente não resolveu o problema do déficit habitacional.

Nesse governo, destaca-se a aprovação do Estatuto das Cidades, em 2001, que regulamenta os artigos 182 e 183 da Constituição Federal, estabelecendo diretrizes gerais da política urbana. O Estatuto criou uma série de instrumentos visando o desenvolvimento urbano, como o plano diretor e a gestão democrática da cidade, além de servir como suporte para a criação do Ministério das Cidades, em 2003. 
O Ministério das Cidades foi criado durante o Governo Lula (2003-2010) como órgão coordenador, gestor e formulador da Política Nacional de Desenvolvimento Urbano e gestor das Políticas Habitacionais. Tem como objetivo universalizar o acesso à moradia, promover a urbanização, tornar a questão habitacional prioridade nacional, democratizar o acesso à terra urbanizada, aumentar a produtividade e melhorar a qualidade na produção habitacional; incentivar a geração de empregos e renda através da indústria da construção.

Porém, o Ministério das Cidades encontra limitações para a gestão habitacional, como afirma Bonduki (2008), pois as operações financeiras são centralizadas na Caixa Econômica Federal (CAIXA), subordinada ao Ministério da Fazenda, fazendo com que o poder de decisão pertença à Caixa.

Ainda no início do governo Lula, a Política Habitacional foi baseada em vários princípios e programas propostos na PNH de 1996, dando continuidade à mesma. Os princípios da PNH já compunham o Projeto Moradia do primeiro governo Lula (2003-2006), afirma Bonduki (2008). Marcada pela descentralização, propôs instrumentos para incrementar parcerias entre a União, os estados, os municípios e a iniciativa privada. Observa-se também, diretrizes de buscar novas fontes de financiamentos, assim como manter o equilíbrio econômico-financeiro do sistema. Apesar da continuidade, há um esforço para privilegiar o atendimento das classes de renda mais baixas (até seis salários mínimos), colocando a política habitacional mais próxima da parcela da população sujeita ao déficit.

Como visto, a produção de moradias insuficiente, principalmente para as famílias de baixa renda, é um problema comum aos diferentes períodos de governo, acarretando no crescimento do déficit habitacional. Os programas habitacionais até então estabelecidos pelo poder público não reverteram a crise habitacional estabelecida desde o início do século, trabalhando com uma visão restrita do habitar e enfatizando a provisão da unidade casa, independente da integração com outras políticas e da mobilidade urbana.

É nesse contexto da política habitacional que se destaca o Programa Minha Casa, Minha Vida (PMCMV), apresentado como uma resposta do governo à crise econômica mundial de $2008^{3}$ para impulsionar o mercado da construção civil, gerar empregos e ao enfrentar o déficit habitacional brasileiro, concentrado na população da faixa de renda de até três salários mínimos.

\footnotetext{
${ }^{3}$ A crise financeira de 2008 foi a maior do capitalismo desde a grande depressão de 1929. Começou nos Estados Unidos após o colapso da bolha especulativa no mercado imobiliário, alimentada pela grande expansão de crédito bancário e potencializada pelo uso de novos instrumentos financeiros, espalhando-se pelo mundo todo em poucos meses. (OUREIRO, José Luis. Artigo escrito para o jornal Valor Econômico em 13/09/2011. Disponível em: http://www.valor.com.br/opiniao/1004628/origem-causas-e-impacto-da-crise)
} 


\section{PROGRAMA MINHA CASA MINHA VIDA}

Como já abordado nesse estudo, um dos itens mais importantes do passivo social brasileiro é a questão habitacional, que abrange tanto os aspectos ligados à moradia quanto os diferentes serviços de infra-estrutura essenciais a uma vida digna.

Dessa forma, o Programa Minha Casa Minha Vida (PMCMV) surge, segundo a cartilha do PMCMV, como uma iniciativa governamental com o objetivo de contribuir para a redução do déficit habitacional brasileiro, proporcionando habitação digna e adequada aos que enfrentam condições precárias de moradia (MINISTÉRIO DAS CIDADES, 2009).

O programa, que faz parte do Programa de Aceleração do Crescimento (PAC), foi anunciado como um dos elementos-chave do Governo Lula (2003-2010) para impulsionar o crescimento da economia brasileira e enfrentar os efeitos da crise global de 2008, através de uma série de medidas com a intenção de estimular a produção habitacional e manter o desenvolvimento do setor da construção civil, tendo como meta a construção de um milhão de moradias para famílias com renda de até dez salários mínimos.

Segundo a Caixa (2009), o PMCMV faz parte de uma política anticíclica que tem como objetivo aumentar os investimentos no setor da construção civil e garantir a geração de emprego e renda e, assim, mitigar os impactos da crise econômica mundial. A justificativa é que estimulando a produção de moradias, a indústria da construção cresce gerando empregos e, ao mesmo tempo, enfrentando a questão da precariedade de moradia da maior parte da população brasileira.

Dias (2012) esclarece a participação e importância das empresas de construção civil na elaboração do PMCMV afirmando que inicialmente empresários e movimentos sociais estavam juntos em uma proposta de combate ao déficit habitacional antes da eclosão da crise financeira. Contudo, a dinâmica da crise introduziu o interesse do Palácio do Planalto, fazendo com que a proposta anterior perdesse força e o Planalto passasse a articular um plano diretamente com as principais construtoras do país e a CBIC, que representa as médias e pequenas construtoras em nível nacional.

A construção civil proporciona um grande efeito multiplicador sobre a atividade econômica, sendo a construção de moradias um dos principais segmentos desta indústria. Desta forma, o incremento do estoque habitacional poderia dar impulso ao desenvolvimento econômico, gerando empregos, renda e produção, condições necessárias para minimizar os imensos problemas sociais que afligem o país (CARMO, 2006 ).

Entretanto, como afirmam Rolnik e Nakano (2009) uma "boa" política de geração de emprego e renda na construção civil não significa necessariamente uma "boa" política habitacional. 
O PMCMV é o maior programa habitacional brasileiro desde o BNH (ARANTES, 2009). Foi criado pela Medida Provisória no 459, de 25 de março de 2009 e transformado na Lei no 11.977, de 7 de julho de 2009, com a meta de construir um milhão de moradias, aumentando o acesso das famílias de baixa renda à casa própria.

Sua finalidade é criar mecanismos de incentivo à produção e aquisição de novas unidades habitacionais, requalificação de imóveis urbanos e produção ou reforma de habitações rurais, para famílias com renda mensal de até dez salários mínimos (MINISTÉRIO DAS CIDADES, 2009).

Trata-se de um conjunto de soluções aos principais problemas apontados pelos estudos da Fundação João Pinheiro (FJP) através da abordagem, principalmente, dos aspectos econômicos dos financiamentos habitacionais, com a concessão de subsídios às famílias das classes sociais mais pobres. (D’AMICO, 2010).

Além disso, o objetivo do governo federal foi dirigir o setor imobiliário para atender à demanda habitacional de baixa renda. Ou seja, fazer o mercado habitacional incorporar setores que até então não tiveram como adquirir a mercadoria moradia de modo regular e formal, estimulando a criação de empregos e renda através do aumento de investimentos no setor da construção civil (ARANTES e FIX, 2009).

Assim, o programa pretende atingir duas políticas habitacionais: a política anticíclica, aumentando o investimento na construção civil e a geração de emprego, e a política social, aumentando o acesso à casa própria, minimizando o déficit habitacional brasileiro.

O PMCMV foi, segundo Cardoso e Aragão (2013) fortemente inspirado nas experiências chilena e mexicana que foram consideradas pelos representantes do setor empresarial como as mais adequadas para dinamizar a produção habitacional.

O PMCMV compreende dois subprogramas: Programa Nacional de Habitação Rural - PNHR e o Programa Nacional de Habitação Urbana - PNHU, objeto desse estudo.

O PNHR tem como objetivo a concessão de subsídios aos agricultores para a construção ou reforma de moradia em área rural, por meio da aquisição de material de construção.

Já o PNHU é destinado às famílias com renda mensal de até dez salários mínimos (SM) ${ }^{4}$, divididas em três faixas de renda, que em 2009 eram:

. Faixa I- 0 a 3 Salários Mínimos - R\$ 0,00 a R\$ 1.395,00

. Faixa II - 3 a 6 Salários Mínimos - R\$ 1.395,01 a R\$ 2.790,00

\footnotetext{
${ }^{4}$ O salário mínimo vigente em 2009 era de $\mathrm{R} \$ 465,00$.
} 
. Faixa III - 6 a 10 Salários Mínimos - R\$2.790,01 a $\mathrm{R} \$ 4.650,00$

O programa prevê que o governo federal disponibilize recursos financeiros para a concessão de subsídios para auxiliar os beneficiários na aquisição de moradias, e que empresas que desejarem participar do programa, apresentem projetos para a Caixa.

As famílias com renda de até três salários mínimos têm direito a subsídios habitacionais integral. As famílias com renda de três a seis salários mínimos tem direito a subsídio parcial em financiamentos (cujo objetivo é complementar a capacidade financeira para o pagamento do imóvel), redução dos custos do seguro e acesso ao Fundo Garantidor, que assegura o equilíbrio econômico das instituições ou agentes financeiros junto ao SFH.

Já as famílias que recebem entre seis e dez salários mínimos têm direito a condições especiais de financiamento imobiliário utilizando os recursos do FGTS e estímulo à compra com redução dos custos do seguro e acesso ao Fundo Garantidor.

Entretanto, Cardoso (2011), explica que a execução do programa se dá em duas vertentes principais: habitações para população com renda de até três salários mínimos e com renda de três a dez salários mínimos.

O PMCMV foi dividido para que o Governo Federal pudesse implantar subsídios governamentais a serem utilizados pelas famílias de baixa renda das áreas urbanas e rurais. Esses recursos podem ser utilizados pelos agentes financeiros do SFH para assegurar o equilíbrio econômico financeiro dos empréstimos habitacionais concedidos para as classes sociais mais pobres D'Amico (2010).

Os recursos financeiros do PMCMV são oriundos do Orçamento Geral da União. A União disponibilizou recursos também oriundos de outras fontes, como o Fundo Garantidor da Habitação FGHab, o Fundo de Arrendamento Residencial - FAR e o Fundo de Desenvolvimento Social - FDS, por exemplo. Além disso, a União destinou recursos ao Banco Nacional de Desenvolvimento Social - BNDES com o objetivo de equalizar os juros criando assim, uma espécie de subsídio para a construção civil.

A Lei 11.977 também autorizou à União transferir recursos diretamente aos municípios com até cinqüenta mil habitantes, exigindo dos municípios condições mínimas de infra-estrutura urbanas, saneamento e sustentabilidade ambiental. Ao todo, os recursos da primeira fase do programa pretendiam envolver o total de 25,5 bilhões de reais.

A meta da primeira fase do Programa foi o acesso a um milhão de moradias por parte de famílias com renda de até dez salários mínimos até o final de 2010, sendo:

- Quatrocentas mil unidades às famílias com renda bruta de até três salários mínimos .

- Quatrocentas mil unidades às famílias com renda bruta de três até seis salários mínimos; e 
. Duzentas mil unidades a famílias com renda bruta de seis à dez salários Mínimos.

A primeira fase do Programa superou a meta de financiar um milhão de moradias e atingiu, segundo o Ministério das Cidades ${ }^{5}$, a marca de 1.005 .128 unidades habitacionais até 31 de dezembro de 2010, com investimentos acima de $\mathrm{R} \$ 53$ bilhões.

\section{Agentes e Recursos}

O Programa Minha Casa Minha Vida pretende atingir sua meta através da parceria entre União, Estados, municípios, empreendedores e movimentos sociais.

Podemos identificar os seguintes agentes na primeira fase do PMCMV:

. O Ministério das Cidades como gestor da aplicação;

. A Caixa Econômica Federal como agente financeiro e operador;

. O Ministério da Fazenda responsável pelo repasse dos recursos;

- As construtoras, responsáveis pela execução dos projetos de acordo com as normas do Programa;

- E os beneficiários finais: pessoas físicas com renda familiar de até dez salários mínimos.

Entretanto, Bonduki (2008) ressalta a limitação do Ministério das Cidades frente à gestão dos recursos para a habitação, pois as operações financeiras de recursos do PMCMV são centralizadas na Caixa Econômica Federal, subordinada ao Ministério da Fazenda. Assim, o poder de decisão quanto aos financiamentos e gestão de projetos fica, na prática, a critério da Caixa.

Para empreendimentos destinados à famílias com renda de até três salários mínimos, o Poder Estadual e Municipal tem responsabilidade de cadastrar, gratuitamente, as famílias interessadas e assinar o Termo de Adesão com a CAIXA, visando assegurar a sua colaboração na implementação dos projetos e execução do Trabalho Social junto aos beneficiários dos empreendimentos implantados. Compete também aos municípios a doação de terrenos, quando for o caso, para a construção dos empreendimentos habitacionais.

As construtoras apresentam os projetos às superintendências regionais da CAIXA que, após análise simplificada, contrata a operação, acompanha a execução da obra e libera recursos conforme cronograma. Concluído o empreendimento, a CAIXA analisa os selecionados para verificar se tem renda

\footnotetext{
${ }^{5}$ Dados enviados por email pelo Departamento de Produção Habitacional do Ministério das Cidades.
} 
compatível, imóvel, possui financiamento habitacional ou problema no CADIN (Cadastro Informativo de créditos não quitados do setor público federal).

A participação das prefeituras no PMCMV também ocorre (ou deveria ocorrer) através da regularização fundiária dos assentamentos urbanos que visam à regularização dos assentamentos irregulares garantindo o direito à moradia, desenvolvendo as funções sociais da propriedade urbana e preservando o equilíbrio ambiental da construção.

As Zonas Especiais de Interesse Social (Zeis), parcelas de área urbana destinadas à moradia de baixa renda, sujeitas a regras específicas de ocupação e uso do solo, também podem ser disponibilizadas pelos Municípios através dos Planos Diretores, o que poderia proporcionar terrenos adequadamente localizados.

A construção das unidades habitacionais ocorre a partir da contratação de empreendimentos em condomínio ou em loteamento, constituídos de apartamentos ou casas e são financiadas segundo a faixa de renda do beneficiário.

Para famílias com renda até três salários mínimos os recursos provêm do Fundo de Arrendamento Residencial - FAR ou do Fundo de Desenvolvimento Social - FDS, se as famílias estiverem organizadas sobre a forma de cooperativas, associações, entidades. Já para famílias com renda até dez salários mínimos, os recursos são originados do Fundo de Garantia do Tempo de Serviço - FGTS (CAIXA, 2009).

Os financiamentos também podem ser concedidos diretamente a pessoas físicas destinados à compra de casas prontas e financiadas pelas próprias construtoras. A regra é que podem ser incluídas moradias que receberam o "habite-se" a partir da vigência do programa.

A União destinou $R \$ 2,5$ bilhões a titulo de subvenção econômica, para facilitar a aquisição, produção e requalificação do imóvel residencial de famílias com renda mensal de até seis salários mínimos, nas regiões urbanas.

Também disponibilizou uma série de recursos em outros tipos de programas e fundos, como o Fundo Garantidor da Habitação Popular (FGHab), dividido em cotas que podem ser adquiridas pelos agentes financeiros do SFH. Por lei, a União poderá alocar R\$2 bilhões nesse fundo destinado aos agentes financeiros do SFH para cobrir eventuais inadimplências no pagamento das prestações das unidades habitacionais, desde que a falta de pagamento decorra de desemprego ou redução da capacidade de pagamento das famílias com renda até dez salários mínimos, reduzindo o risco de inadimplência para as instituições financeiras (D'AMICO, 2010). 
A União também destinou $\mathrm{R} \$ 5$ bilhões ao Banco Nacional de Desenvolvimento Econômico e Social (BNDES), como uma espécie de subsídio para as construtoras e empreiteiras.

Para o Fundo de Arrendamento Residencial (FAR) destinou $\mathrm{R} \$ 14$ bilhões e $\mathrm{R} \$ 500$ milhões para Fundo de Desenvolvimento Social.

Já para os municípios com até 50 mil habitantes, a União foi autorizada a transferir até $\mathrm{R} \$ 1$ bilhão, totalizando $\mathrm{R} \$ 25,5$ bilhões distribuídos entre os programas, fundos e agentes do PMCMV.

Para os mais pobres, o subsídio é alto e no caso de inadimplência, o risco de despejo é zero (a única penalidade é não receber o título da moradia enquanto não forem quitadas as prestações). Para os demais, que entram em financiamentos convencionais, mas também subsidiados, o governo estabeleceu um "fundo garantidor" para fornecer um colchão público no caso de inadimplência.

Entretanto, de acordo com Arantes e Fix (2009), para os sem-teto $1^{6}$, o atendimento previsto na primeira fase do Programa era para apenas $14 \%$ do déficit habitacional.

Os projetos do PMCMV para famílias acima de três salários mínimos são apresentados pelas construtoras, analisados e contratados pela CAIXA. Esta recebe os recursos alocados pela União, verifica o atendimento às regras estabelecidas como infraestrutura, condições do projeto arquitetônico, avaliação do valor de mercado das unidades habitacionais, orçamento da obra e análise do cronograma físico-financeiro e financia a construção e/ou aquisição do imóvel.

O Ministério das Cidades prioriza os municípios candidatos ao PMCMV que implementam os instrumentos previstos no Estatuto da Cidade que ampliam o acesso à terra urbanizada, como as ZEIS. Segundo Rolnik org. et.al. (2010) "para que o Programa Minha Casa Minha Vida construa moradias adequadas e bem localizadas é essencial a participação ativa dos municípios mobilizando instrumentos em seus Planos Diretores que favoreçam a disponibilidade de bons terrenos para o programa, especialmente para famílias com renda de 0 a 3 salários mínimos."

\footnotetext{
${ }^{6}$ Trabalhadores informais ou desempregados sem comprovação de renda fixa mensal.
} 


\section{O PROGRAMA POR FAIXAS DE RENDA}

Nessa pesquisa, optou-se por utilizar as vertentes apresentadas por Cardoso (2011) dividindo o Programa em duas faixas de renda: de 0 a 3 salários mínimos e de 3 a $10 \mathrm{sm}$, pois as regras e características do programa para as Faixas 2 e 3 (de 3 a 6 e 6 a 10sm) não possuem diferenças significativas para esse trabalho.

\section{O A 3 SALÁRIOS MÍNIMOS}

No caso de unidades habitacionais para famílias com renda de até três salários mínimos, correspondente a $89,6 \%$ do déficit Habitacional (FJP, 2011), a Caixa Econômica Federal paga empreiteiras que apresentem propostas para a construção de moradias em áreas onde há deficit habitacional e, após concluída a obra, os imóveis são repassados a famílias cadastradas pelo banco.

Para essa faixa de renda, a provisão habitacional pode ocorrer de três modos:

. Via construtora;

. Via doação de terra pelo Estado/Município;

. Via entidade organizadora.

A produção através das construtoras ocorre por oferta privada ao poder público, com valores entre 37 e 52 mil reais por unidade na primeira fase, dependendo do tipo de município e da modalidade de provisão (TABELA 6).

Isso significa que a construtora define o terreno e o projeto, aprova junto aos órgãos competentes e vende integralmente o que produzir para a Caixa Econômica Federal, sem gastos de incorporação imobiliária e comercialização, sem risco de inadimplência dos compradores ou vacância das unidades (FIGURA 1).

Entretanto, financeiramente não há interesse por parte das construtoras em empreendimentos destinados a essa faixa de renda. Segundo Gregório (2011), os empreendimentos nessa faixa de renda trazem resultados apertados para a atratividade do investimento e requerem muita cautela na escolha do terreno e engenharia do produto como um todo. 
TABELA 6: VALOR MÁXIMO DE AQUISIÇÃO DAS UNIDADES.

\begin{tabular}{|c|c|c|c|}
\hline \multirow{2}{*}{ UF } & \multirow{2}{*}{ Localidade } & \multicolumn{2}{|c|}{ Valor Máximo de Aquisição } \\
\hline & & Apartamento & Casa \\
\hline \multirow[t]{2}{*}{ SP/DF } & $\begin{array}{l}\text { RMs de SP, Jundiaí, São } \\
\text { José dos Campos, } \\
\text { Jacareí e DF }\end{array}$ & $\mathrm{R} \$ 52.000,00$ & $\mathrm{R} \$ 48.000,00$ \\
\hline & Demais Municípios & $\mathrm{R} \$ 46.000,00$ & $\mathrm{R} \$ 42.000,00$ \\
\hline \multirow{3}{*}{ RJ } & Capital & $\mathrm{R} \$ 51.000,00$ & $\mathrm{R} \$ 47.000,00$ \\
\hline & RMs & $\mathrm{R} \$ 49.000,00$ & $R \$ 45.000,00$ \\
\hline & Demais Municípios & $\mathrm{R} \$ 42.000,00$ & $R \$ 38.000,00$ \\
\hline \multirow{2}{*}{ MG } & Capital e RMs & $\mathrm{R} \$ 46.000,00$ & $R \$ 42.000,00$ \\
\hline & Demais Municípios & $\mathrm{R} \$ 42.000,00$ & $R \$ 38.000,00$ \\
\hline \multirow{2}{*}{ BA } & Capital e RMs & $\mathrm{R} \$ 46.000,00$ & $\mathrm{R} \$ 42.000,00$ \\
\hline & Demais Municípios & $\mathrm{R} \$ 41.000,00$ & $R \$ 37.000,00$ \\
\hline \multirow{2}{*}{$\mathrm{PE} / \mathrm{CE}$} & Capital e RMs & $\mathrm{R} \$ 45.000,00$ & $\mathrm{R} \$ 41.000,00$ \\
\hline & Demais Municípios & $\mathrm{R} \$ 41.000,00$ & $R \$ 37.000,00$ \\
\hline $\mathrm{RS} / \mathrm{PR} / \mathrm{SC}$ & & $\mathrm{R} \$ 45.000,00$ & $R \$ 41.000,00$ \\
\hline AC/AM/AP/PA RO/RR & & $\mathrm{R} \$ 43.000,00$ & $\mathrm{R} \$ 39.000,00$ \\
\hline TO & & $\mathrm{R} \$ 42.000,00$ & $\mathrm{R} \$ 38.000,00$ \\
\hline $\mathrm{ES} / \mathrm{MT} / \mathrm{MS} / \mathrm{GO}$ & & $\mathrm{R} \$ 42.000,00$ & $R \$ 39.000,00$ \\
\hline AL/RN/PB/PI SE/MA & & $\mathrm{R} \$ 41.000,00$ & $\mathrm{R} \$ 37.000,00$ \\
\hline
\end{tabular}

Fonte: Ministério das Cidades. Portaria 93.

FIGURA 1: FLUXOGRAMA DA PRODUÇÃO DAS UNIDADES VIA CONSTRUTORA.

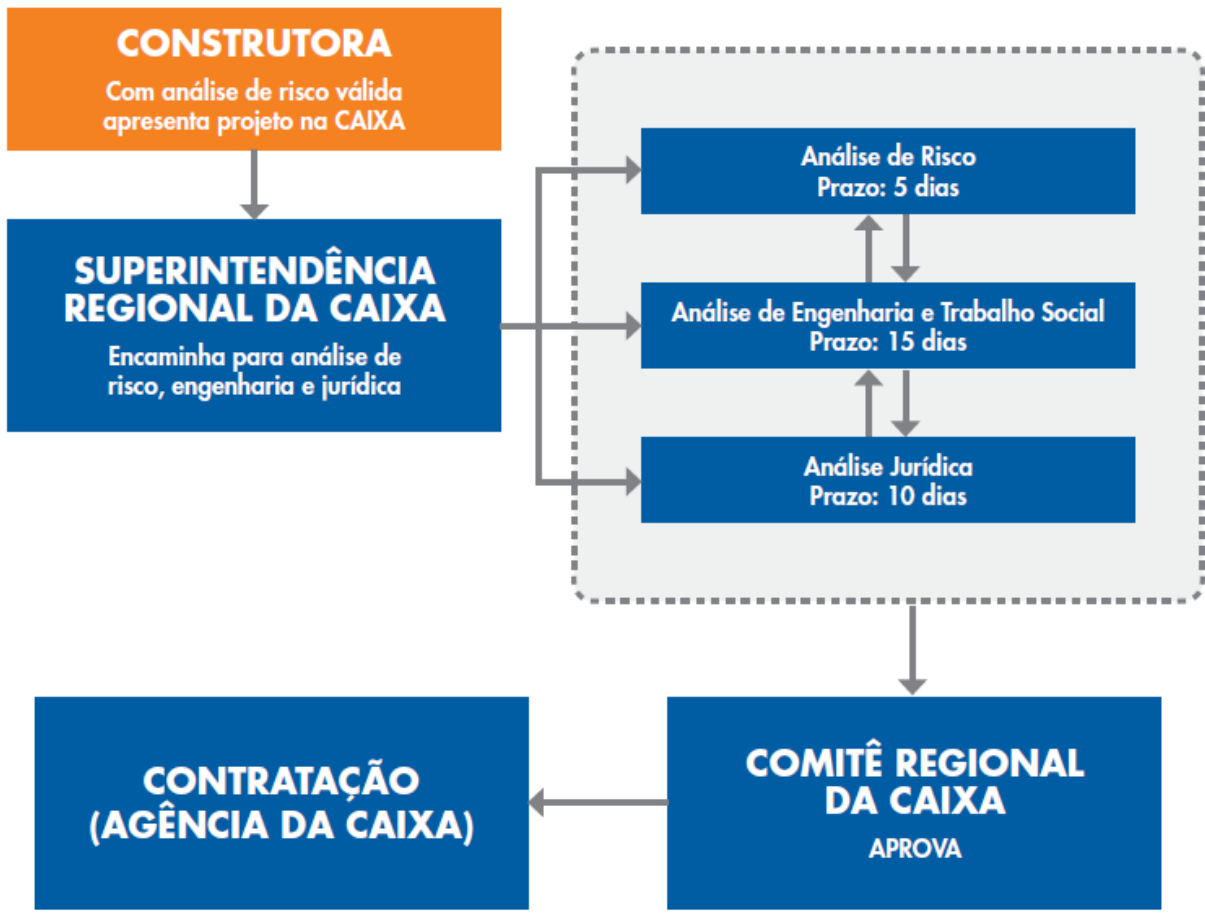

Fonte: Caixa Econômica Federal. Cartilha Completa Minha Casa Minha Vida. Disponível em http://downloads.caixa.gov.br/_arquivos/habita/mcmv/CARTILHACOMPLETA.PDF 
Já via município (FIGURA 2), a prefeitura disponibiliza a doação do terreno junto ao FAR e seleciona a empresa construtora, que apresenta anteprojeto e planilha de custos, através de um processo formal para escolha da melhor proposta.

O governo estadual ou municipal assina o Termo de Adesão com a CAIXA. A partir desse momento a CAIXA passa a receber propostas de aquisição de terreno e produção de empreendimentos para análise junto com a documentação necessária

FIGURA 2: FLUXOGRAMA DA PRODUÇÃO DAS UNIDADES VIA DOAÇÃO DE TERRA PELO MUNICÍPIO.

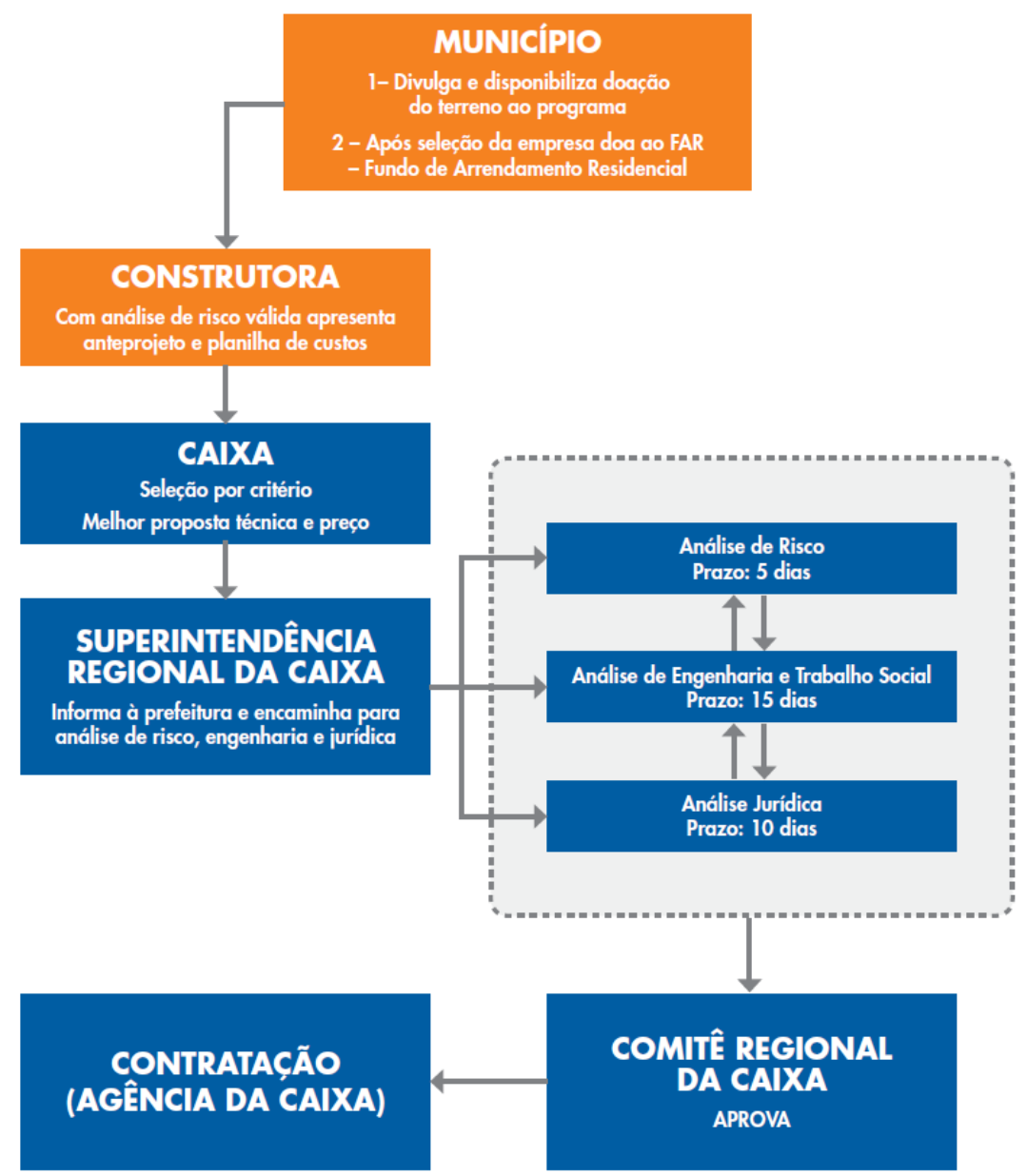

Fonte: Caixa Econômica Federal. Cartilha Completa Minha Casa Minha Vida. Disponível em http://downloads.caixa.gov.br/_arquivos/habita/mcmv/CARTILHACOMPLETA.PDF

Estados e Municípios indicam à CAIXA as famílias a serem beneficiadas, de acordo com os critérios definidos para o Programa e as construtoras apresentam projetos. 
Após análise, a CAIXA contrata a operação. A execução das obras é realizada pela construtora contratada pela CAIXA, que se responsabiliza pela entrega dos imóveis concluídos e legalizados. Após a conclusão da obra os imóveis são adquiridos pelas famílias beneficiadas diretamente na CAIXA.

O manual da CAIXA determina que os projetos de condomínios e loteamentos devam ter no mínimo as seguintes características:

. Inserção na malha urbana

- Existência prévia de infraestrutura básica que permita as ligações domiciliares de abastecimento de água, esgotamento sanitário, energia elétrica, vias de acesso e transportes públicos

. Existência de infraestrutura para a coleta de lixo e drenagem urbana

- Existência ou ampliação dos equipamentos e serviços relacionados à educação, saúde e lazer

As entidades organizadoras - EO, que são associações, cooperativas e demais entidades sem fins lucrativos devem se habilitar previamente no Ministério das Cidades e apresentarem projetos à CAIXA, podendo fazê-lo em parceria com estados e municípios.

A CAIXA envia ao a relação de projetos para seleção ao Ministério das Cidades, que vai escolher o melhor e repassar à Caixa. As EO apresentam a demanda a ser atendida para a CAIXA, que efetua a análise, contrata a operação, libera recursos conforme cronograma e acompanha a execução da obra. (FIGURA 3)

FIGURA 3: FLUXOGRAMA DA PRODUÇÃO DAS UNIDADES VIA ENTIDADES ORGANIZADORAS.

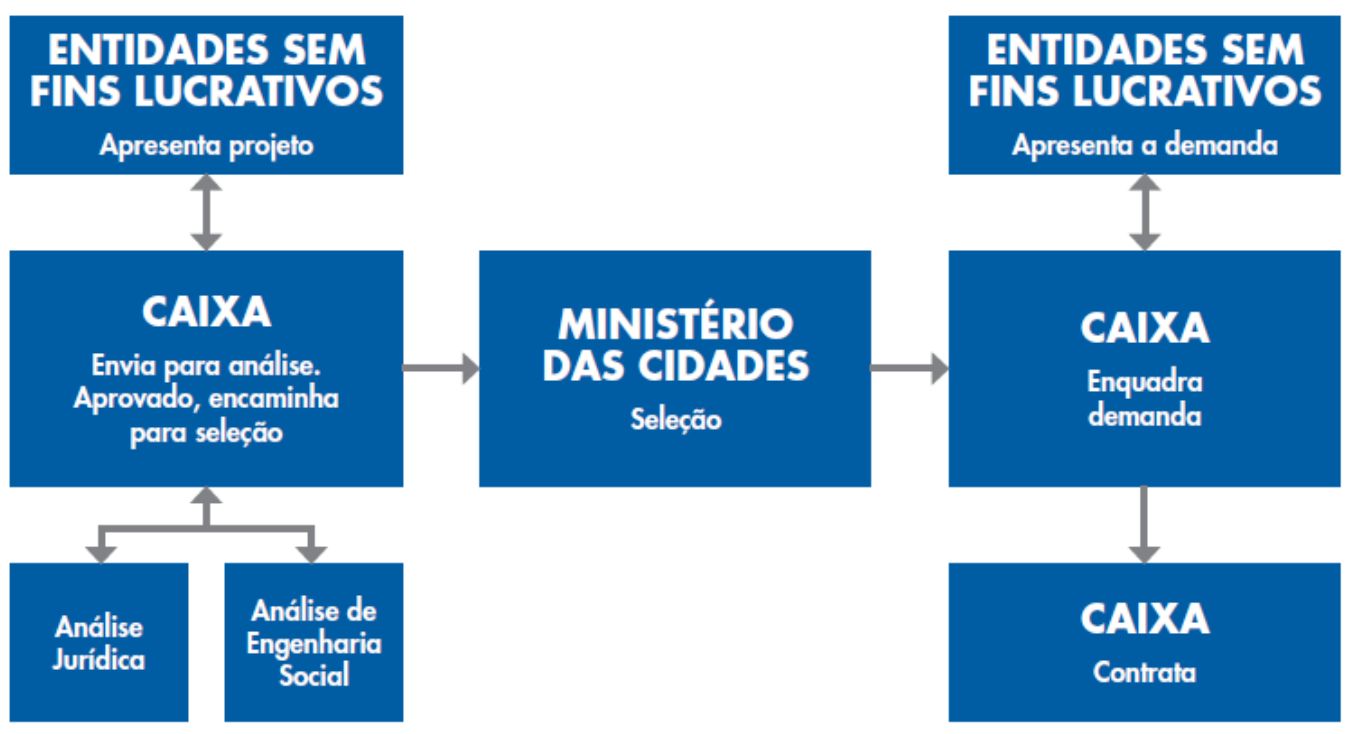

Fonte: Caixa Econômica Federal. Cartilha Completa Minha Casa Minha Vida. Disponível em http://downloads.caixa.gov.br/_arquivos/habita/mcmv/CARTILHACOMPLETA.PDF 
A exigência é de que a situação fundiária deve ser regular ou em processo de regularização, a área deve ser definida no plano diretor municipal, e com infraestrutura básica de água, energia elétrica, acesso viário, soluções de esgoto sanitário e serviços públicos essenciais de transporte e coleta de lixo. (MINISTÉRIO DAS CIDADES, 2009).

No triênio 2009-2011, 400 mil unidades habitacionais urbanas e rurais estavam previstas para essa faixa, denominada de "interesse social", sempre com subsídio orçamentário da União.

Assim, como Arantes e Fix $(2009$,$) afirmam os projetos não são definidos como parte da$ estratégia municipal de desenvolvimento urbano, sendo estritamente concebidos como mercadorias.

Mesmo os órgãos competentes estão pressionados em todas as instâncias a obter resultados quantitativos para cumprir as metas do programa.

Para essa faixa de renda, a taxa de subsídio é alta, variando entre $60 \%$ a $90 \%$. As famílias devem pagar $10 \%$ de seu rendimento ou o mínimo de 50 reais por mês, com juros zero, por um período de 10 anos (MINISTÉRIO DAS CIDADES, 2009).

Os requisitos para ser beneficiário são: não ter sido beneficiado anteriormente em programas de habitação social do governo; não possuir casa própria ou financiamento em qualquer UF; estar enquadrado na faixa de renda familiar do programa.

As tipologias variam entre casa térrea com $36 \mathrm{~m} 2$ ou apartamentos com $39 \mathrm{~m} 2$, com limites de até 500 unidades por módulo, ou condomínios segmentados em 250 unidades (FIGURAS 4 e 5). 0 acabamento mínimo exigido é piso cimentado liso, paredes pintadas, revestimentos no Box do banheiro e parede hidráulica da cozinha e laje ou forro de madeira ou PVC.

Entretanto, Cardoso e Aragão (2013), mostram que a média de unidades na faixa de 0-3 SM, nas regiões metropolitanas, é de 1023 unidades por empreendimento agrupado, o dobro do limite legal. No Nordeste, onde a precariedade das periferias é mais aguda, essa média chega a 1.400 unidades.

Enquanto a família recebe uma casa com apenas $36 \mathrm{~m} 2$ de área útil, provavelmente em um loteamento nas periferias extremas, a empreiteira pode receber por essa casa-mercadoria até 48 mil reais, um valor cujo preço do $\mathrm{m} 2$ (1,4 mil reais) chega a ser três vezes superior ao custo do $\mathrm{m} 2$ dos mutirões autogeridos dos movimentos populares de São Paulo, que obtém ganhos graças ao trabalho gratuito dos futuros moradores e à gestão sem lucro dos projetos e obras (ARANTES e FIX, 2009). 
FIGURA 4: TIPOLOGIA PADRÃO DE CASA TÉRREA PARA FAMÍLIAS COM RENDA ATÉ 3 SM.

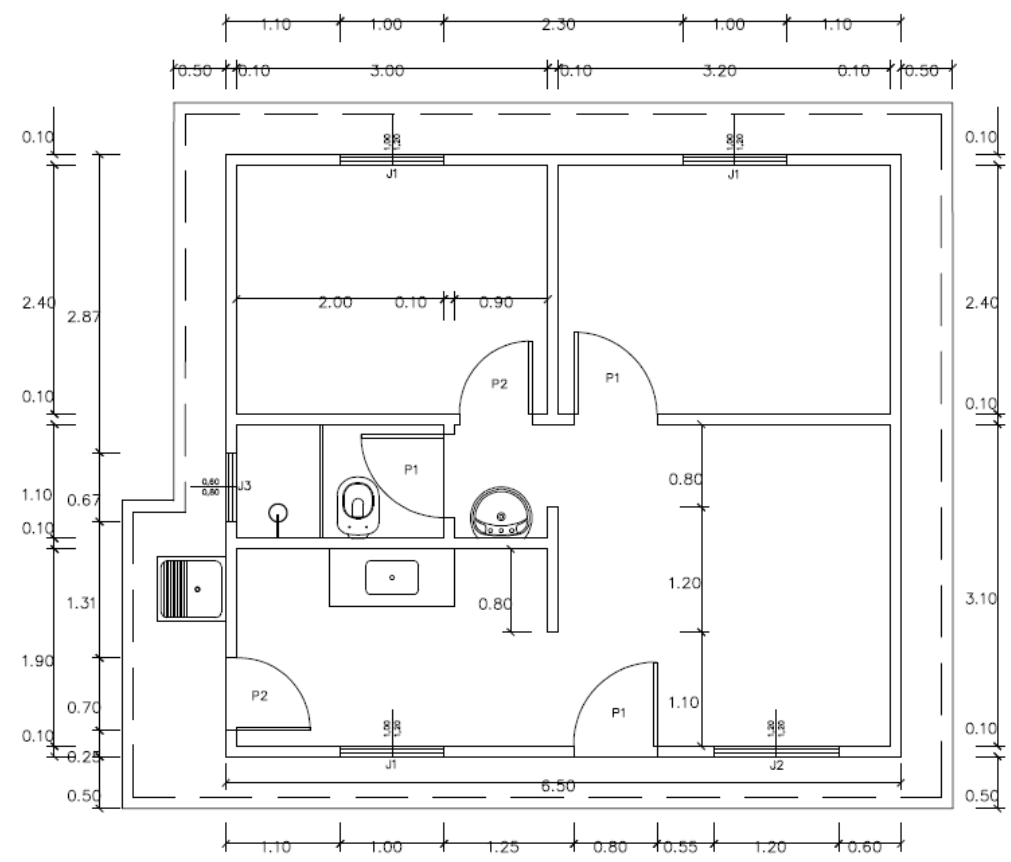

Fonte: Caixa Econômica Federal. Cartilha Completa Minha Casa Minha Vida. Disponível em http://downloads.caixa.gov.br/_arquivos/habita/mcmv/CARTILHACOMPLETA.PDF

FIGURA 5: TIPOLOGIA PADRÃO DE APARTAMENTO PARA FAMÍLIAS COM FAIXA COM RENDA ATÉ 3 SM.

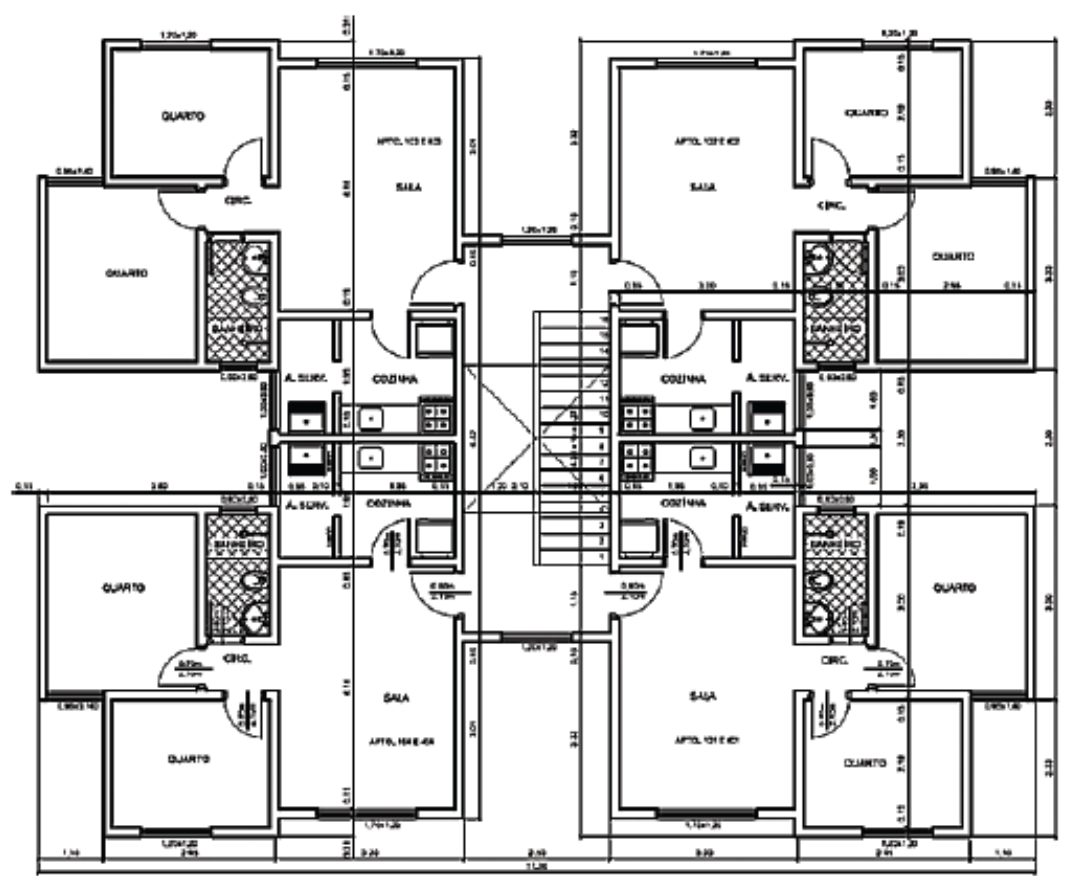

Fonte: Caixa Econômica Federal. Cartilha Completa Minha Casa Minha Vida. Disponível em http://downloads.caixa.gov.br/_arquivos/habita/mcmv/CARTILHACOMPLETA.PDF 
Apesar de quase $90 \%$ do déficit habitacional se concentrar nessa faixa de renda apenas $40 \%$ dos imóveis pretendidos pelo programa foram destinados para essa demanda. Além disso, no primeiro semestre de 2011 não houve desembolso por parte da Caixa para essa faixa de renda. O presidente da Caixa Econômica Federal, Jorge Hereda", justificou que "Não houve operações neste primeiro semestre apenas para famílias na faixa até três salários mínimos. O governo estava revendo as especificações, melhorando a qualidade e as condições das unidades habitacionais e também revendo os custos".

Os dados revelam que a faixa de renda até $3 \mathrm{sm}$ é incontestavelmente a mais necessitada de respostas imediatas quanto ao acesso a terra, à infraestrutura, aos serviços urbanos, à moradia e ao crédito. Entretanto, além da redução de apenas 7,13\% do déficit habitacional concentrado nessa faixa de renda (NASCIMENTO e TOSTES, 2011), essas foram as únicas contratação que pararam enquanto eram ajustadas.

\section{A 10 SALÁRIOS MÍNIMOS}

No caso de unidades para famílias com renda entre três e dez salários mínimos, o programa garante financiamento às construtoras, que posteriormente vendem as unidades habitacionais segundo valores definidos com base na renda das famílias.

Os recursos são do FGTS e contemplam subsídios de até 23 mil reais, mais redução nos juros, em montante inversamente proporcional ao rendimento familiar. Os valores ficam entre 80 e 130 mil reais (TABELA 7), faixa que interessa às construtoras que atuam nos chamados mercados para a classe média baixa. Nesse caso a comercialização é feita diretamente pelas empresas e o interessado vai diretamente aos estandes de vendas ou aos "feirões da casa própria" patrocinados pela Caixa.

TABELA 7: VALOR MÁXIMO DE AQUISIÇÃO PARA FAMÍLIAS COM RENDA ENTRE 3 E 10 SM.

\begin{tabular}{|l|c|}
\hline \multicolumn{1}{|c|}{ Município } & Valor \\
\hline Regiões Metropolitanas em SP, RJ e DF & $\mathrm{R} \$ 130 \mathrm{mil}$ \\
\hline $\begin{array}{l}\text { Municípios com mais de } 500 \text { mil habitantes e demais capitais } \\
\text { estaduais e seus municípios limítrofes }\end{array}$ & $\mathrm{R} \$ 100 \mathrm{mil}$ \\
\hline Demais minicípios & $\mathrm{R} \$ 80 \mathrm{mil}$ \\
\hline
\end{tabular}

Fonte:Caixa Econômica Federal, 2009.

A construtora apresenta o projeto e constrói o empreendimento. A CAIXA paga o empreendimento e, após conclusão das obras, analisa os selecionados para verificar a renda, se já

\footnotetext{
${ }^{7}$ http://www.correiobraziliense.com.br/ app/noticia/politica-brasil-economia/2011/06/06/ internas_polbraeco,255622/recursos-para-a-2-fase-do-minha-casa-minha-vida-podem-chegar-a-r-140-mi.shtml
} 
possuem imóvel ou outro financiamento habitacional, a capacidade de pagamento e problemas cadastrais (MINISTÉRIO DAS CIDADES, 2009). (FIGURA 6).

As famílias podem adquirir os imóveis com o subsídio parcial em financiamentos através do FGTS, com redução dos custos do seguro e Acesso ao Fundo Garantidor. O comprometimento da renda para pagamento da prestação pode ser de até $20 \%$.

Nesta modalidade os empreendimentos não têm especificação padrão determinada, sendo permitido no máximo 500 unidades por módulo.

FIGURA 6: FLUXOGRAMA DA PRODUÇÃO DE UNIDADES PARA FAMÍLIAS COM RENDA ENTRE 3 E 10 SM.

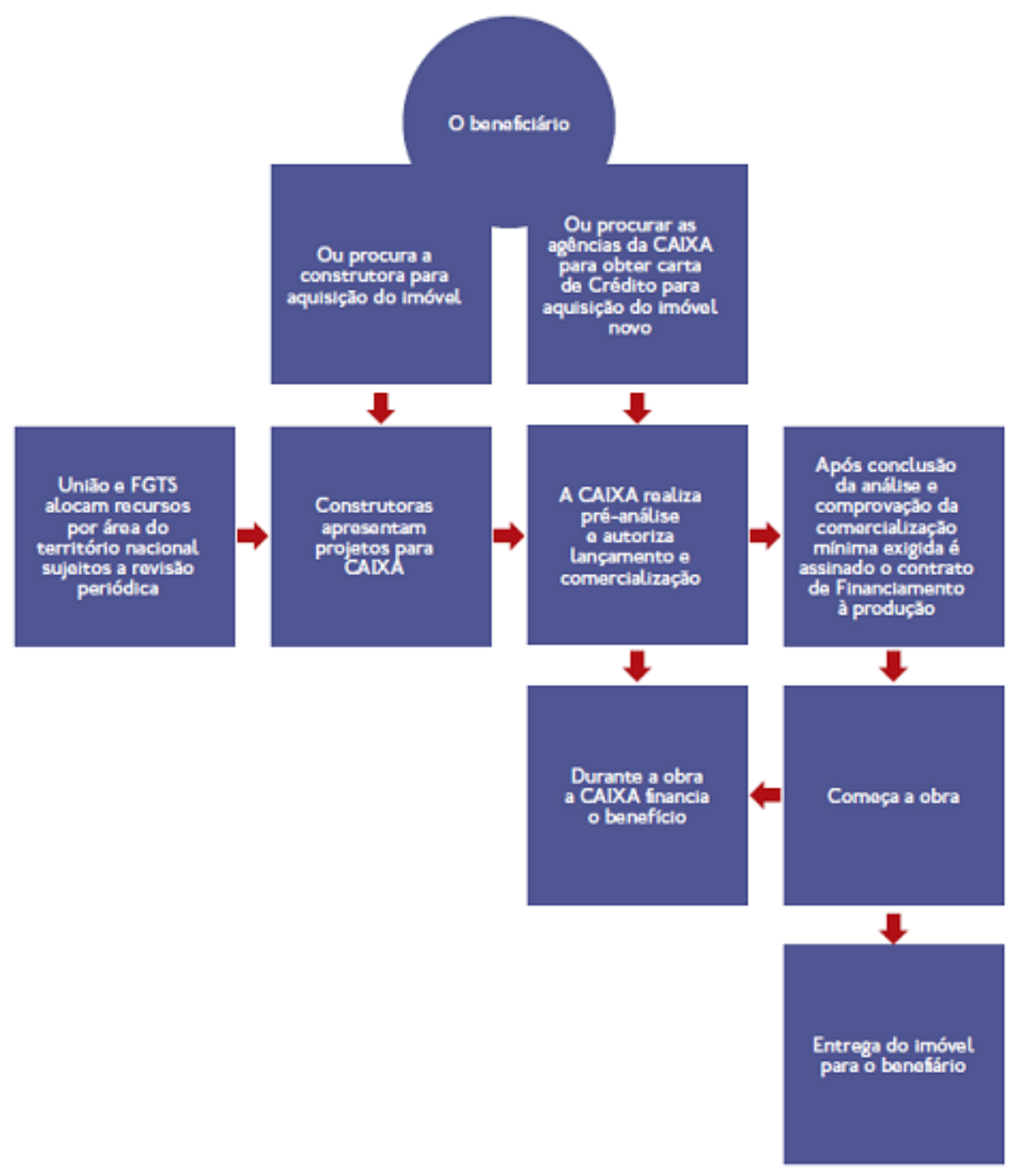

Fonte: ROLNIK, R. (org.) Como produzir moradia bem localizada com recursos do programa minha casa minha vida?: implementando os instrumentos do Estatuto da Cidade. Brasília: Ministério das Cidades, 2010. 
O déficit habitacional urbano de famílias entre três e dez salários mínimos corresponde a apenas $9,8 \%$ do total (FJP, 2008), mas recebeu $60 \%$ das unidades e $53 \%$ do subsídio público (ARANTES e FIX, 2009). Segundo o Ministério das Cidades, até o final de 2011, foram contratadas 517.308 unidades destinadas às famílias que recebem até $3 \mathrm{sm}$, mas somente 68.408 unidades haviam sido entregues. Já para as famílias de 3 a $10 \mathrm{sm}$, das 819.937 unidades contratadas, 384.620 unidades foram entregues.

Como mostrado no Gráfico 5, o número de unidades contratadas voltadas às famílias de 3 a 10 sm satisfaz o mercado imobiliário, que a considera mais lucrativa. Enquanto isso, 89,6\% do déficit habitacional urbano concentra-se abaixo dos 3 salários mínimos, e recebeu menos de $40 \%$ das unidades contratadas, o que corresponde pouco mais de $7 \%$ do total do déficit para esta faixa.

Como afirmam Arantes e Fix (2009), "tais dados evidenciam que o atendimento aos que mais necessitam se restringirá, sobretudo, ao marketing e à mobilização do imaginário popular

\section{GRÁFICO 5: DÉFICIT HABITACIONAL X UNIDADES CONTRATADAS.}

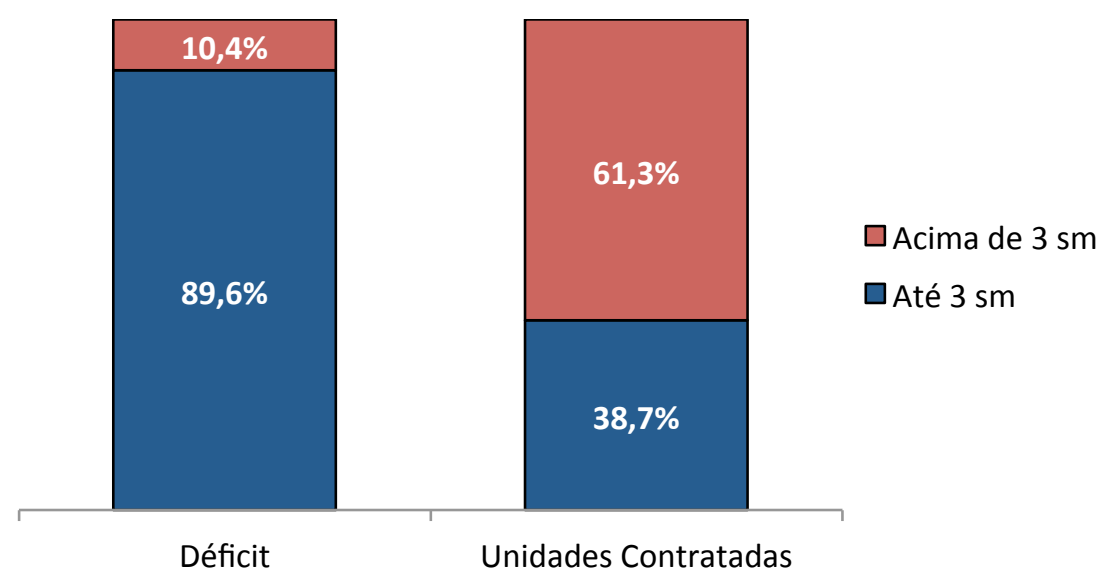

Fonte: Fundação João Pinheiro, 2011; Ministério das cidades, 2011. Elaborado pela autora.

\section{MINHA CASA MINHA VIDA 2}

Em março de 2010 o Governo Federal anunciou um novo programa de investimentos em continuidade ao Programa de Aceleração do Crescimento (PAC). O novo programa - o PAC 2 - envolve R\$ 1,55 trilhão de recursos, distribuídos em sua maior parte para o período 2011-2014, para serem utilizados em Programas de transportes, energia, infraestrutura urbana, ofertas de equipamentos públicos, tratamento de água, acesso a luz e água limpa e habitação. 
Em junho de 2011 o Governo Federal lançou a segunda fase do Programa Minha Casa Minha Vida, programa habitacional do PAC 2, que pretende financiar a construção de 2 milhões de unidades habitacionais até 2014. O Quadro 1 mostra que, para a segunda fase do programa foram feitos alguns ajustes e alterações procurando corrigir deficiências observadas na fase anterior, como alteração nos valores dos imóveis, renda dos beneficiários, especificações e metragem das unidades habitacionais, adaptações para os portadores de necessidades especiais entre outros.

QUADRO 1: PRINCIPAIS MUDANÇAS ENTRE O MCMV1 E MCMV2.

\begin{tabular}{|l|c|c|}
\hline Principais Mudanças & MCMV1 & MCMV2 \\
\hline Número de Unidades Totais & 1.000 .000 & 2.000 .000 \\
\hline Número de Unidades Faixa 1 & 400.000 & 1.200 .000 \\
\hline Faixa de Renda 1 & $\mathrm{R} \$ 1.395,00$ & $\mathrm{R} \$ 1.600,00$ \\
\hline Faixa de Renda 2 & $\mathrm{R} \$ 2.790,00$ & $\mathrm{R} \$ 3.100,00$ \\
\hline Faixa de Renda 3 & $\mathrm{R} \$ 4.650,00$ & $\mathrm{R} \$ 5.000,00$ \\
\hline Valor Máximo das Unidades para a Faixa 1 & $\mathrm{R} \$ 52.000,00$ & $\mathrm{R} \$ 65.000,00$ \\
\hline Valor Máximo das Unidades para as Faixas 2 e 3 & $\mathrm{R} \$ 130.000,00$ & $\mathrm{R} \$ 170.000,00$ \\
\hline Tipologia Casas Faixa 1 & $35 \mathrm{~m} 2$ & $39,6 \mathrm{~m} 2$ \\
\hline Tipologia Apto Faixa 1 & $42 \mathrm{~m} 2$ & $45,5 \mathrm{~m} 2$ \\
\hline Bancos Participantes & Caixa & Caixa e Banco do Brasil \\
\hline Meta de Volume de Investimento & 25,5 bilhões de reais & 127,5 bilhões de reais \\
\hline
\end{tabular}

Fonte: Caixa Econômica Federal, 2011; Ministério das Cidades, 2011.

Elaborado pela autora.

Entre as mudanças para a nova fase do Programa merecem destaque:

O aumento no número de moradias - mais 2 milhões de unidades habitacionais

Maior volume de investimentos - serão investidos R\$ 125,7 bilhões entre 2011 e 2014. Esse aumento no volume de investimento deve-se à alguns fatores conjuntos: aumento do número de unidades a serem construídas; aumento no valor máximo das unidades; e ao volume real gasto na primeira fase, de mais de 53 bilhões de reais, superando a meta dos 25,5 bilhões.

Ampliação das faixas de renda e prioridade às famílias de baixa renda. As Faixas 1 (de 0 a 3 sm) passou de $R \$ 1395,00$ para $R \$ 1600,00$. A Faixa 2 (de3 a $6 \mathrm{sm}$ ) foi de $R \$ 2790,00$ para $R \$ 3100,00$ e a Faixa 3 (de 6 a 10 sm) de $R \$ 4650,00$ a $R \$ 5000,00 . a$

- A meta de atendimento para as famílias que recebem até 3 sm subiu de 40 para $60 \%$. Assim, 1,2 milhão de moradias serão destinadas a faixa de renda mais necessitada.

- O valor médio de moradias para famílias de baixa renda passou de $\mathrm{R} \$ 42.000,00$ para $\mathrm{R} \$$ $55.000,00$ e a área construída das casas foi ampliada de $35 \mathrm{~m}^{2}$ para $39,6 \mathrm{~m}^{2}$ e dos apartamentos 
foi de $42 \mathrm{~m}^{2}$ para $45,5 \mathrm{~m}^{2}$, com a intenção de melhorar a acessibilidade para idosos e pessoas com dificuldades de locomoção. As casas e apartamentos contarão com azulejos em todas as paredes da cozinha e banheiro, piso cerâmico em todos os cômodos e portas e janelas maiores. As casas ainda terão energia solar para aquecimento de água, colaborando para a diminuição dos gastos com energia.

Para imóveis das faixas 2 e 3 de renda, os tetos, que já haviam sido ajustados no início de 2011, permanecem os mesmos: $\mathrm{R} \$ 170$ mil nas regiões metropolitanas de São Paulo, Rio de Janeiro e Distrito Federal; R\$150 mil nas demais capitais e cidades com mais de um milhão de habitantes; $\mathrm{R} \$ 130$ mil nos municípios com população maior que 250 mil habitantes ou inseridos em outras regiões metropolitanas; $\mathrm{R} \$ 100$ mil nas cidades com mais de 50 mil habitantes; e $\mathrm{R} \$ 80$ mil nas demais localidades.

- As mulheres chefes de família poderão assinar contratos independente do seu estado civil. Antes elas necessitavam da assinatura do cônjuge, o que dificultava o seu acesso ao programa.

- Haverá um limite mínimo para o tamanho de portas e janelas a fim de assegurar melhoria nas condições de iluminação e ventilação.

Além da Caixa Econômica Federal, o Programa contará com a Participação do Banco do Brasil em todas as modalidades do programa.

O número máximo de unidades por condomínio passou de 500 para 300.

Os estados e municípios que doarem terrenos localizados em área urbana consolidada para implantação de empreendimentos vinculados ao programa teraõ prioridade nos projetos do PMCMV.

As edificações voltadas para a Faixa 1 poderão conter unidades destinadas à atividade comercial, desde que os valores recebidos pela atividade sejam destinados integralmente ao custeio do condomínio. As unidades comerciais não poderão ser alienadas e são válidas para áreas centrais e de grande adensamento urbano.

A concessão prioritária de financiamento é para famílias chefiadas por mulheres, desabrigadas ou que residam em áreas de risco e insalubres. De acordo com estudo do Instituto de Pesquisa Econômica Aplicada (Ipea), 22 milhões de famílias brasileiras são chefiadas por mulheres. Esse valor representa 35\% das famílias em 2009, contra 27\% em 2001.

O Ministério das Cidades também afirma que as novas unidades habitacionais construídas no âmbito do programa estarão necessariamente localizadas fora de áreas de risco. As favelas e áreas em situação de risco abrigam 2,2 milhões de famílias, onde 77,7\% recebem até três salários mínimos. 
Segundo a Secretaria Nacional de Defesa Civil, de novembro de 2010 a março de 2011, 203 mil pessoas ficaram desabrigadas ou desalojadas em todo o País.

Considerando isoladamente o fluxo anual de investimentos voltado ao Programa Minha Casa, Minha Vida 2, de R\$ 69,5 bilhões, observa-se a criação de 1,4 milhão de emprego. Verifica-se então que, dentro do PAC 2, o programa habitacional responde por $51 \%$ do total de postos de trabalho e por apenas $29 \%$ do total de investimentos no período 2011-2014. Do total de 1,4 milhão de empregos, 984 mil serão gerados no próprio setor de construção e 450 mil nos demais setores.

Rolnik (2011) analisa as mudanças afirmando que "não há evidências de que o aumento da renda dos brasileiros esteja acompanhando o aumento dos preços dos imóveis; nesse cenário, a compra da casa própria para a população de baixa renda ficará cada vez mais inacessível; e, claramente, os subsídios públicos estão indo parar no bolso dos proprietários".

Segundo o Governo Federal, uma nova regra também permite a aquisição de imóveis, por meio do programa, nas áreas em processo de desapropriação, em operações de urbanização de favelas e assentamentos precários.

Nesses casos, é possível a aquisição e cessão dos direitos de posse. Ao final do processo de desapropriação, o direito de propriedade do imóvel será transferido às famílias beneficiárias, informou o governo.

De acordo com o Palácio do Planalto, a segunda fase do programa também conta com aperfeiçoamento de regras para aumentar a sua eficiência. Nos casos de famílias de menor renda, o imóvel só poderá ser vendido antes de dez anos se a família quitar o seu valor total, incluindo o subsídio, informou o governo. O objetivo dessa regra é evitar a venda precoce do imóvel (BRASIL, 2011).

Para operações do Fundo de Garantia do Tempo de Serviço, resolução do Conselho Curador prevê renda familiar mensal bruta de até $\mathrm{R} \$ 5,4$ mil para habitação popular no caso de imóveis em cidades de regiões metropolitanas ou com população superior a 250 mil habitantes. Nos demais municípios, o limite é $R \$ 3,9$ mil.

Entretanto, mais uma vez o programa não abrangeu o financiamento à produção e aquisição de lotes urbanizados. Este incentivo estava previsto na Medida Provisória que criou o MCMV 1 em 2009, mas foi vetado pela presidência quando da conversão em Lei. A justificativa foi a de que este incentivo não garantia o atendimento a um dos principais objetivos do programa: Maior geração de emprego e renda por meio da criação de demanda para o setor da construção civil. 


\section{RELAÇÃO COM PROGRAMAS ANTERIORES}

Como visto, a construção de habitações populares em grande escala já ocorreu no passado, principalmente com investimentos do Banco Nacional da Habitação (BNH).

A análise crítica sobre essa fase da política habitacional brasileira traz aprendizados importantes que precisam ser levados em conta no debate atual. Desde a criação do $\mathrm{BNH}$, o uso dos recursos do Fundo de Garantia por Tempo de Serviço (FGTS) em financiamentos para a produção de empreendimentos habitacionais dinamizou o mercado imobiliário de médio e alto padrão nas cidades brasileiras, provocando grande aumento no preço de terrenos (ROLNIK, 2009).

Dos 4,5 milhões de moradias erguidas com financiamentos do Sistema Financeiro de Habitação (SFH) entre 1964 e 1986, apenas 33,5\% se destinaram à população de baixa renda e foram implantados nas periferias urbanas, onde a terra era barata por não haver acesso a infraestruturas nem equipamentos comunitários de educação, saúde, lazer e cultura.

Entretanto, o crédito imobiliário durante esse período nunca alcançou a faixa de renda familiar mensal entre 0 e 3 salários mínimos.

Uma das âncoras do "milagre econômico" foi o boom imobiliário, que durou até o início dos anos 1980. A construção civil também levou os trabalhadores migrantes para as cidades, pagando os menores salários e oferecendo as piores condições, mas sem exigir qualificação prévia. As empresas de construção identificavam nessa época um pólo de negócios, pois sempre havia demanda para este produto

Nesse sentido, Arantes e Fix (2009) afirmam que o BNH estabeleceu um sistema muito mais completo e complexo do que o atual, com a perspectiva de uma política econômica de crescimento econômico continuado. $\mathrm{O}$ objetivo era o de expansão capitalista sem necessariamente a repartição de seus ganhos, concentrados principalmente nas classes médias urbanas e empresas privadas. 0 sistema habitacional do regime atuava como fortalecedor da expansão da mercadoria habitação.

O PMCMV e sua operação de marketing retomam, ainda segundo os autores, a 'ideologia da casa própria' que foi estrategicamente difundida no Brasil durante o regime militar. Essa proximidade se destaca ao dirigir as atenções das classes populares para a conquista da propriedade privada ofuscando a necessidade de mudanças mais profundas, como uma verdadeira reforma urbana.

O programa atual foi feito às pressas, sem de fato constituir um sistema consistente e duradouro de financiamento do setor (ARANTES e FIX, 2009). Mas apresenta duas novidades: um maior foco para baixa renda, com subsídios superiores aos oferecidos pelo BNH dirigidos aos mais pobres; e a extensão da oferta para todas as faixas de renda. O crédito imobiliário do BNH não alcançou as famílias 
com renda de até $3 \mathrm{SM}$, expulsando-as para moradias autoconstruídas ou grandes conjuntos habitacionais, localizados nas periferias urbanas sem infraestrutura, serviços, equipamentos e empregos. O resultado, segundo Rolnik (2009), o foi o aumento da favelização e da autoconstrução em loteamentos precários e irregulares país afora.

O fato do poder público assumir a responsabilidade pela demanda do que for construído para o público de 1 a 3 salários mínimos no PMCMV, somado a concessão de um subsídio para auxiliar o comprador na quitação do preço, mitiga os riscos do incorporador.

Isso não quer dizer que se está evitando a construção de grandes conjuntos periféricos, ao contrário, pois a racionalidade ambiciosa que movimenta a operação é a mesma, assim como a manutenção do padrão de segregação social (ARANTES e FIX, 2009). Como afirmam Almeida e Amato (2011), cabe "ao incorporador um desafio, controlar e até reduzir o custo de construção destes empreendimentos." Como isso está sendo feito é a grande questão.

Para "reduzir" os custos, muitos empreendimentos são localizados em locais afastados, onde o acesso à infraestrutura, equipamentos urbanos e ao trabalho são mais escassos, porém o valor do terreno é mais barato. Utilizam materiais de construção de baixa qualidade, ocasionando patologias construtivas logo após a entrega das unidades, como no condomínio Santa Bárbara, em Feira de Santana. No total 380 casas foram entregues ao valor de 40 mil reais e apresentaram rachaduras, infiltrações hidráulicas e elétricas invertidas. Também é comum encontrar plantas mal distribuídas e outras inúmeras deficiências ${ }^{8}$.

Uma outra forma mais positiva de reduzir os custos tem sido a introdução de inovações tecnológicas através da industrialização, com a promoção de estudos de pré-fabricação com qualidade através do SINAT (Sistema Nacional de Avaliação Técnica), pertencente ao PBQP-H (Programa Brasileiro da Qualidade e Produtividade do Habitat), com o objetivo de avaliar novos produtos utilizados nos processos de construção.

A análise de projetos e a contratação de obras continuam a cargo de uma instituição financeira, a Caixa Econômica Federal. Ainda que o Programa seja uma oportunidade de minimizar o déficit habitacional, seria apropriado evitar as bases que lhe deram forma para não sofrer os mesmos impactos negativos da era BNH.

Cabe ressaltar que o BNH, última grande política brasileira em habitação, entre as décadas de 60 e 80, seguiu caminho parecido: o banco estimulou um boom imobiliário, mas os crescentes custos para os empréstimos geraram alta inadimplência, que acabou por levá-lo à falência.

\footnotetext{
${ }^{8}$ http://video.globo.com/Videos/Player/Noticias/0,,GIM1598766-7823-CASAS+DE+CONDOMINIO+DO+MINHA+CASA+MINHA+ VIDA+SAO+ENTREGUES+COM+PROBLEMAS+ESTRUTURAIS,00.html. Acesso em 09/09/2011.
} 
De acordo com Hirata (2010), o plano lançado pelo presidente Lula serve-se dos mesmos mecanismos utilizados pela ditadura militar. Assim como no BNH, não existe controle efetivo dos recursos pelas classes populares e pelos movimentos sociais. Ainda segundo a autora, os movimentos sociais não têm autonomia no direcionamento das obras. São poucos os mecanismo no programa que imponham ou viabilizem a participação popular sobre as decisões ou o controle social sobre os recursos.

Quase meio século depois, permanece na atual política habitacional a mesma lógica de funcionamento do $\mathrm{BNH}$, estruturada pela produção com baixo custo e alta rentabilidade das construtoras. Como colocam Nascimento e Tostes (2011), a preocupação com a racionalização dos processos para garantir a produção em massa, acentuadas pelo desejado de desenvolvimento da indústria da construção, impediu que o BNH incorporasse a reabilitação dos centros urbanos, a provisão da moradia para a população de baixa renda e a geração de espaços públicos democraticamente acessíveis.

Parece que a lição sobre as políticas habitacionais anteriores ainda hão de ser aprendidas.

Além do BNH, é possível notar semelhanças do PMCMV com outros programas. Percebe-se que as diretrizes da atual política habitacional estão assentadas em vários princípios e programas propostos na Política Nacional de Habitação (PNH) de 1996, como a descentralização, propondo instrumentos para incrementar parcerias entre a União, estados, municípios e esfera privada; a inclusão de parte importante da população mais pobre ao acesso a moradia; a busca por novas fontes de financiamentos.

Entretanto, Bonduki (2009) identifica algumas propostas que estavam presentes no PNH e não foram consideradas no PMCMV, como a desarticulação com a política urbana e o subsídio localização, valor adicional concedido aos empreendimentos habitacionais loca-lizados nas áreas mais centrais e consolidadas.

Assim, a base do Programa Minha Casa Minha Vida já havia sido desenhada pelo Governo Fernando Henrique nos anos 90, quando definiram um modelo de provisão baseado na oferta privada e na racionalidade do capital, capturando fundos públicos, com o suporte de um banco como agente operador.

\section{CONSIDERAÇÕES SOBRE O PROGRAMA}

A casa própria ainda é tida pelas camadas populares como garantia da sobrevivência familiar, ainda mais em tempos de crise. No Brasil, representa a garantia de uma velhice mais segura e digna na ausência ou insuficiência da previdência social. Também é a garantia de uma estabilidade em relação à 
escola dos filhos, aos laços de com a comunidade, à segurança real e simbólica de não ser ameaçados ou vitimados pelo despejo em caso de desemprego (ARANTES e FIX, 2009).

O grande diferencial do PMCMV para os demais programas do Governo Federal para tentar amortizar o déficit habitacional é o aporte de recursos e o acesso à moradia por parte da população mais necessitada: famílias que recebem até 3 salários mínimos.

A ampliação da produção de mercado essa faixa de renda é estratégica para o enfrentamento do déficit habitacional, pois se o setor privado não produzir moradias para as faixas de renda média e média baixa, este segmento, que tem mais capacidade financeira, pode adquirir as habitações produzidas para a população de baixa renda (BONDUKI, 2008).

Entretanto, como visto anteriormente, o Programa foi elaborado como uma política de governo em resposta à crise de 2008, em compromisso com representantes dos setores imobiliários e da construção, desconsiderando os avanços institucionais na área de desenvolvimento urbano e a interlocução com outros setores da sociedade civil.

Assim, os municípios tiveram grande dificuldade em promover a construção de moradias para os moradores mais pobres, já que o programa prevê menor margem de retorno para esse tipo de investimento.

Cardoso e Aragão (2013), indentificam alguns pontos que estão sendo mal equalizados pelo Programa, entre eles:

- Falta de articulação do programa com a política urbana;

- Problemas de localização dos novos empreendimentos;

- Grande escala dos empreendimentos;

- Baixa qualidade arquitetônica e construtiva dos empreendimentos;

- Perda do controle social sobre a sua implementação.

Além disso, o programa apresenta contradições entre os objetivos de combater a crise, estimulando a economia, e os objetivos de combater o deficit habitacional.

O Programa também está direcionado de forma abrangente para um país de características heterogêneas no qual existem diferenças regionais nos preços dos terrenos, custos de construção e formas de compor a renda do trabalhador brasileiro.

Dessa forma, não trata de forma clara a preocupação com a qualidade do produto e seu impacto ambiental. O repertório de soluções para a habitação social é ignorado na formulação do pacote e nas moradias padrão apresentadas pela Caixa Econômica. As duas tipologias propostas pela Caixa foram 
divulgadas pela instituição como solução padrão para todo o território nacional, desconsiderando condições climáticas, culturais e geográficas diferenciadas do Brasil. (ARANTES e FIX, 2009)

O uso das tipologias pré-aprovadas agiliza prazos e diminui o tempo de análise de projetos, tornando-se referência para incorporadores imobiliários. Arantes e Fix (2009) afirmam que os empresários "não pretendem fazer nada melhor ou maior para a faixa de 0 a 3 salários, sob pena de reduzirem seus lucros, e até já estudam a supressão de paredes internas das unidades habitacionais."

A casa térrea apresentada como exemplo pela Caixa para a segunda fase do Programa tem 36 m2 de área útil, com cômodos mínimos. Pode-se argumentar que a família vai fazer a casa crescer por autoconstrução, os projetos devem inclusive prever isso. Já o apartamento tem $39 \mathrm{~m} 2$ de área útil e a área construída não pode ser ampliada pelo morador. Para famílias com mais de 4 pessoas, segundo Arantes e Fix (2009) nos cadastros de um movimento de sem-teto de São Paulo, elas chegam a 40\% da demanda), a área por habitante é cerca de $10 \mathrm{~m} 2$ por pessoa, o que produz sobrelotação, problemas de salubridade, falta de espaço para as crianças estudarem e brincarem, além de favorecer a violência doméstica e sexual.

Cabe observar também que, apesar do número máximo de unidades por empreendimento imposta pela caixa ser de 500 unidades as construtoras facilmente extrapolam esse número, aprovando projetos em terrenos contíguos, mas com as mesmas tipologias arquitetônicas, soluções construtivas e implantação nos terrenos.

Mesmo não superando a condição da forma-mercadoria, o pacote poderia qualificar minimamente os projetos de habitação popular. Para tanto, poderia mobilizar arquitetos, engenheiros, universidades e laboratórios de pesquisa, avaliar referências internacionais e nacionais, favorecer critérios de sustentabilidade ambiental das edificações e dos sistemas de saneamento etc.

Uma tentativa de qualificação para os projetos do programa foi feita no início de 2011, quando o Governo Federal convidou o arquiteto João Filgueiras Lima, um dos maiores especialista em obras com pré-fabricados, mais conhecido como Lelé, para elaborar os projetos das unidades do PMCMV localizadas em encostas.

O arquiteto apresentou dois projetos para regiões de favelas de Salvador: a urbanização da favela de Pernambués, com ocupação mista de apartamentos e casas geminadas, e o conjunto habitacional para Cajazeiras (REVISTA AU, 2011). Mas as soluções podem ser adaptadas a qualquer parte do País. A proposta inclui creche, escola, área de lazer. Além disso, a proposta contempla a forma de vida da população local, prevendo espaços para pequenas oficinas. As construções propostas são racionalizadas e com estrutura mista metálica com argamassa armada fabricadas no local em minifábricas, com capacidade para fazer 40 apartamentos em 45 dias. 
Ainda segundo o arquiteto, o uso de pré-fabricado e o conhecimento sobre as funções do prédio podem reduzir o custo das obras pela metade de um similar feito por empreiteira.

Além desse 'cuidado' com as encostas, não se encontra qualquer preocupação com a qualidade do produto e seu impacto ambiental. A despreocupação, principalmente na faixa de 0 a 3 salários, é também decorrente do fato de que a demanda é tão grande, que não pode sequer fazer escolhas e exigências mínimas.

Nas discussões sobre o problema habitacional no Brasil, é frequente a proposta de que o mercado imobiliário absorva o contingente de desempregados de nossa sociedade. Acredita-se que a utilização de mão-de-obra não especializada é uma característica intrínseca da indústria da construção civil (DE PASCHOAL, 2009).

Sobre o caráter anticíclico do programa, não há dúvida de que a construção civil é uma empregadora maciça de mão-de-obra. Mas, segundo Arantes e Fix (2009) a qualidade dos empregos gerados é questionável. A busca pelo menor custo viável por unidade habitacional pode resultar no uso de mão de obra sem qualificação, acarretando em construções duvidosas e futuras patologias.

Os autores ainda destacam que o apelo da geração de empregos não especializados funciona como forma de pressão social, principalmente em relação ao sistema financeiro, baseado em poupanças para alocar financiamentos às atividades de construção de habitações. Dessa forma, os programas habitacionais referem-se mais ao financiamento, não estando vinculados à estratégia de ocupação do solo.

Existe o desafio de estabelecer parâmetros que garantam um desempenho mínimo desejado por parte do governo, considerando as restrições de custo nesse segmento. Esses parâmetros são essenciais para evitar problemas posteriores que possam comprometer a vida útil das construções e gerar prejuízos pessoais, sociais e financeiros aos usuários desses edifícios (SILVA, MORO e PARISI, 2010).

Visando reduzir os custos da construção, os empreendedores podem optar pelo método construtivo mais econômico para conseguir adequar-se ao programa. A Caixa exige o respeito às normas técnicas aplicáveis e ao zoneamento imposto pela legislação local, mas não determina qual o método construtivo deve ser utilizado, apesar de exigir análise dos sistemas construtivos inovadores.

São as construtoras que decidem onde construir, o quê e como, apesar de ser competência dos Municípios doar terrenos para habitações destinadas às famílias de 0 a $3 \mathrm{sm}$. Os municípios deveriam ter um papel mais ativo no processo fortalecendo as estruturas municipais de gestão e controle do uso do solo. 
O governo federal não pode garantir a localização adequada dos empreendimentos se os municípios não estiverem envolvidos. Cabe a eles, por meio de seus planos diretores e habitacionais, definir a melhor localização para implantação de novos projetos. (CARDOSO e ARAGÃO, 2013).

Dessa forma, o PMCMV entrega nas mãos da iniciativa privada o papel principal da provisão habitacional. Segundo Arantes e Fix (2009), os municípios não têm um papel ativo no processo a não ser na exigência de que se cumpra a legislação local, pois a proposta da casa apresentada pela Caixa contraria códigos de obra e legislações municipais em diversas cidades, gerando impasses.

Nesse sentido, se consideramos que a questão da moradia passa separadamente pelas dimensões financeiras na esfera federal e pelas dimensões da terra na esfera municipal, a descentralização política gera um problema de articulação administrativa, já que a eficácia do programa habitacional dependeria de iniciativas governamentais articuladas entre si. Além disso, os Estados ainda não possuem nenhum papel específico sobre o modelo em questão.

O ex Ministro das Cidades Mario Negromonte, em discurso para assinatura da segunda fase do PMCMV em Florianópolis $(2011)^{9}$ ressaltou que o PMCMV só terá sucesso se todas as esferas de governo estiverem envolvidas.

Assim, o planejamento habitacional deveria promover a articulação entre as esferas governamentais e integrar setores como saneamento, transporte, ambiente, para gerar resultados mais positivos. Para Abiko, em um programa desse porte, a preocupação vai além das casas em si. Envolve as questões da terra e infraestrutura, como água, rede elétrica, saneamento e coleta de lixo.

Os equipamentos sociais também são de extrema importância nas áreas de atuação do PMCMV. Sem creches, escolas, postos de saúde, a área pode se degradar.

Entretanto, diversas cidades, como São Paulo, São Carlos e Fortaleza estão recebendo condomínios periféricos, promovendo um crescimento demográfico desequilibrado, além de agressivo ambientalmente. Isso porque o as regiões consolidadas apresentam o $\mathrm{m}^{2}$ muito mais caro. Ainda que a parceria com Estados, municípios, cooperativas e movimentos sociais esteja presente, a estrutura técnica necessária dos projetos dos municípios brasileiros é frágil, permitindo a transferência do processo de tomada de decisões (no que se refere aos aspectos técnicos, ambientais e de qualidade) ao setor da construção civil, com claros benefícios financeiros ao mesmo.

O governo federal, por meio do Ministério das Cidades, reconhece a produção de moradia social em zonas consolidadas e bem localizadas como necessária. Contudo, Nascimento e Tostes (2011)

\footnotetext{
${ }^{9}$ Fonte: Prefeitura de Pomedore. Disponível em http://www.pomerode.sc.gov.br
} 
acreditam que os programas habitacionais brasileiros apresentam diretrizes que indicam a continuidade dos padrões de regulação urbanística elitistas e segregadores.

Além disso, a casa ainda é vista como produto do mercado imobiliário, de modo a garantir maior rentabilidade do capital das construtoras e incorporadoras. Logo, os fatores decisórios na produção habitacional não serão a boa localização nem a existência de infraestrutura ou a qualidade dos projetos.

Segundo Arantes e FIX (2009), o Programa não prepara nem estimula os municípios a aplicarem os instrumentos de reforma urbana previstos no Estatuto da Cidade que estabeleceu, através da Lei no 10.257/01, as bases para a promoção da política urbana no Brasil, fortalecendo o Plano Diretor como principal instrumento para o desenvolvimento urbano. Contudo, até o momento ele foi insuficientemente implementado, não sendo utilizado como elemento definidor dos investimentos.

Infelizmente o Governo ignorou essa questão crucial e a política urbana se reduziu a um grande número de obras, necessárias, porém insuficientes. Há uma grande diferença entre medidas de fomento à construção civil e política habitacional, e o pacote é visto por autores como Rolnik (2009) como mais imobiliário do que habitacional. A própria lógica que orienta o pacote está focada em quantidade de casas, independente das diferentes necessidades habitacionais existentes.

Cardoso e Aragão (2013), ressaltam que "nesse sentido, considerando a falta de articulação da política habitacional com a política urbana e ausência de exigências para que os municípios utilizem os instrumentos do Estatuto das Cidades, a tendência será sempre que os novos empreendimentos se viabilizem a partir da dinâmica de mercado, buscando as terras mais baratas, que são aquelas mais distantes das centralidades urbanas e com maior precariedade de infraestrutura. Um dos problemas anunciados pela própria estrutura institucional e operacional do programa será, portanto, a questão da localização dos novos empreendimentos".

Maricato (2011) afirma que a maior responsabilidade sobre a terra é municipal ou estadual, mas o fato do PMCMV ser inspirado em propostas empresariais causou um grande impacto no preço de imóveis e terrenos entre 2010 e 2011. Com aumento da produção e o mercado aquecido, ocorre o aumento do valor de terrenos, o que inviabiliza a oferta de moradia para a população de baixa renda. Além disso, o financiamento da construção de moradias sem relação com a propriedade fundiária ou sem a função social da propriedade gerou uma transferência de renda para o preço dos imóveis.

O boom imobiliário sem uma adequada regulação fundiária e uma cadeia produtiva sem condições de fornecer os insumos necessários gera uma forte elevação dos valores da terra e dos insumos da construção que terão como desdobramento uma maior dificuldade de atender aos setores que dependem da produção de habitação social. 
Assim, o Programa estimula o crescimento do preço da terra como um todo, favorecendo ainda mais a especulação imobiliária articulada à segregação espacial e tornando a política habitacional de interesse social cada vez mais inviável.

Para Rolnik (2009),o aumento substancial no preço dos terrenos é resultado da falta de uma estratégia fundiária e urbanística. Uma intervenção da magnitude do PMCMV que ignora essa questão acaba alocando a baixíssima renda nos terrenos mais baratos, ou seja, distantes. A autora afirma que "vamos produzir um montão de casas sem cidade, infraestrutura, emprego, reproduzindo nosso modelo clássico de desenvolvimento urbano: Cidade de Deus 2."

Dentro dessa lógica de maximizar a valorização do investimento, as construtoras buscam os terrenos mais baratos e, consequêntemente, mais distantes e com maiores problemas de acessibilidade e infraestrutura.

Infelizmente, nosso sistema de produção habitacional considera a construção como acessório do terreno. O que, segundo De Paschoal (2009) reforça conceitos como:

- Que todos terão casa própria e o dinheiro para adquiri-la. Tal idéia afasta a discussão de habitabilidade, entendida como a existência de infraestrutura e equipamentos urbanos. A "casa própria" se transformou em prioridade e não a moradia, entendida em outros parâmetros de relações urbanas. Em resumo, se discute mais o dinheiro para a habitação do que as soluções propriamente ditas.

- Q Que existe uma "habitação popular". Tal classificação esconde a noção de produtos piores e melhores, menores e maiores. A "habitação popular" é destinada às camadas de baixa renda e qualitativamente inferior. As dimensões reduzidas das residências são frutos da necessidade de aumento do lucro da empresa construtora. A diferença entre os custos de produção e os preços de venda e o dimensionamento do poder aquisitivo da população determinam o retorno das empreiteiras.

A grande questão é a inexistência de um pensamento que relacione a utilização da casa com o seu tamanho e com a viabilidade de atender demandas. E, principalmente, de ser pensada a localização delas no território urbano.

Com o aumento do preço dos terrenos, os conjuntos habitacionais de baixa renda continuam a ser construídos nas periferias das cidades, repetindo os erros do antigo BNH.

No caso da provisão de 0 a $3 \mathrm{sm}$, esse modelo favorece, do ponto de vista urbanístico, a produção de casinhas térreas em grandes conjuntos nas periferias urbanas ou mesmo em área rural que 
será transformada em área urbana. O custo da terra, baixíssimo por metro quadrado, permite o maior ganho de renda por parte das construtoras.

No caso da moradia, a localização constitui fator fundamental de decisão. As moradias inseridas em regiões estratégicas da cidade oferecerão maiores possibilidades de sucesso social, ambiental, urbano e econômico. Segundo o Ministro das Cidades, a decisão principal num programa habitacional desse porte é a escolha da área.

Esse avanço da urbanização periférica tem causado a degradação progressiva de áreas de mananciais, com a instalação de usos e índices de ocupação incompatíveis com a capacidade de suporte do meio.

Em tese, os recursos do PMCMV poderiam ser direcionados para a produção de moradias em terrenos bem localizados e dotados de infraestrutura. Na prática, segundo Nascimento e Tostes (2011) o poder público alimenta o setor imobiliário na medida em que cabe às construtoras não só definir terreno e projeto (localização e tipologia) bem como aprovar legalmente o empreendimento. 0 critério para a escolha de onde construir passa a ser onde há terreno disponível e barato, perdendo a finalidade de priorizar os locais com maior problema de déficit habitacional e com acesso à infraestrutura.

Além de provocar desequilíbrios regionais nos investimentos, o peso dado pelo programa à iniciativa privada faz com que grande parte dos empreendimentos se localize em regiões distantes dos centros urbanos, onde o preço da terra é mais baixo e, na maioria das vezes, há graves problemas de infraestrutura.

Villaça (2001), afirma que a produção do espaço é resultante de uma lógica sucedida das formas de apropriação do espaço por um determinado grupo social deixando as classes mais baixas com as áreas menos disputadas.

A produção de moradias populares para além dos limites da cidade tem consequências graves que acabam prejudicando a todos. Além de encarecer a extensão das infraestruturas urbanas, que precisam alcançar locais cada vez mais distantes, o afastamento entre os locais de trabalho, os equipamentos urbanos e as áreas de moradia aprofundam as segregações socioespaciais e encarecem os custos da mobilidade urbana.

E essas consequências não são exclusivas da periferia, pelo contrário, afetam a cidade como todo. As longas viagens diárias entre a residência e os locais de trabalho congestionam as vias e os transportes coletivos, contribuindo para a poluição do ar, o aquecimento global e as mudanças climáticas. 
Em algumas regiões, como a Grande São Paulo, não existe quantidades razoáveis de terrenos municipais para assentar os projetos do Programa. Sem mobilização de terras, a tarefa está sendo transformar um simples sistema de financiamento em um Programa Habitacional, ainda com eficiência discutível.

Segundo De Paschoal (2009) PMCMV é "um plano sem metas, sem etapas e sem aplicação quantitativa e qualitativa por regiões. Traz até uma "inovação" em planejamento: não tem prazo". É o relançamento do financiamento público pelo governo federal sem nenhuma originalidade, pois existe há mais de 40 anos com o Sistema Financeiro da Habitação, implantado pelo regime militar.

Infelizmente o modo de se abordar o deficit habitacional no país continua desvinculado de questões como urbanização, acesso à terra, gestão urbana e direito à cidade. As obras determinam o processo de urbanização mais do que as leis e Planos Diretores, pois, é comum encontrar planos sem obras e obras sem planos. Assim, a política urbana se reduz à discussão sobre investimentos em obras, vinculada à lógica das campanhas eleitorais (MARICATO, 2011).

Desse modo, o programa não tem conexão com qualquer estratégia urbanística ou fundiária, confundindo política habitacional com política de geração de empregos na indústria da construção.

A oferta de financiamentos imobiliários com recursos públicos não pode se restringir à produção e comercialização de um número " $x$ " de unidades habitacionais e à criação de um número " $y$ " de postos de trabalho no setor da construção civil. Em que pese a importância desses postos para a classe trabalhadora e para a economia do país, os cálculos não devem ser meramente econômicos e quantitativos. Construir moradias é produzir cidades. É essencial discutir os impactos dos empreendimentos imobiliários nas condições de vida, na instituição ou destituição de direitos sociais, no ordenamento territorial e no funcionamento das cidades.

Diversos autores, como Rolnik e Nakano (2009) e Bonduki (2008) defendem a idéia de reciclar os edifícios vazios existentes em áreas com infraestrutura, para buscar regulação territorial, ampliação do acesso à terra urbanizada e desenvolvimento social.

Em algumas regiões como São Paulo, o número de unidades vazias é maior do que o déficit. Entretanto, as classes de menor renda continuam morando nas periferias pois não têm capacidade e possibilidade de adquirir esses imóveis (MARICATO, 2009). Não há estímulo para a ocupação dos mais de 6 milhões de imóveis construídos vagos (FJP, 2011).

Para Cardoso (2011), o estimulo ao uso de áreas desabitadas em regiões centrais também desaceleraria a especulação imobiliária. 
A regulamentação do uso do solo e a demarcação de áreas para investimentos em habitação popular já deveria ser tarefa realizada pelas administrações municipais através dos Planos Diretores. Esse instrumento é responsável pelo planejamento urbano do município, selecionando as áreas capazes de receber empreendimentos sociais e impedir a especulação imobiliária.

Dessa forma o Programa deveria ter como base o Plano Diretor e o Plano Habitacional para que a localização dessas moradias não repita erros antigos que irão prejudicar o adequado desenvolvimento urbano.

Em qualquer lugar do mundo, a produção habitacional é um dos principais motores que impulsiona a urbanização do território. Dependendo das condições em que são produzidas, essa urbanização ocorre com ou sem a geração de cidade. Cabe afirmar que o conceito de cidade e urbano não é o mesmo. O urbano é uma forma de ocupar e transformar os espaços físicos.

É surpreendente que a questão urbana tenha perdido a importância a ponto de ser quase nulo o seu destaque em programas de governo de todos os partidos e estar ausente dos debates nas últimas campanhas eleitorais. Até mesmo a proposta de Reforma Urbana, reconstruída a partir da luta contra o Regime Militar, inspiradora da criação do Ministério das Cidades, que tinha como centralidade a questão fundiária, desapareceu da agenda política.

O mérito do PMCMV é atender parte das necessidades habitacionais dos mais pobres. Mas precisa fazer isso produzindo moradias dignas com cidade.

Caso a oferta de financiamento imobiliário e promoções públicas habitacionais não sejam articuladas com estratégias eficientes de acesso a terras, inseridas na cidade e integradas aos benefícios da vida urbana, o padrão periférico de localização das moradias populares continuará a se reproduzir, em larga escala, nas cidades brasileiras.

Não se pode exigir do programa, isoladamente, a solução para os problemas de planejamento urbano do País, embora esse seja um dos focos do trabalho do Ministério das Cidades. É preciso fortalecer a capacidade de planejamento e gestão territorial nos municípios para viabilizar a produção habitacional destinada a população com renda de até três salários mínimos em áreas inseridas nas cidades, com urbanidade e condições para o desenvolvimento social. Para isso, todos os recursos habitacionais devem ser articulados com as estratégias urbanas definidas pelo Estatuto da Cidade (ROLNIK, 2009 ).

Considerando a dimensão geográfica do país e a complexidade da questão habitacional, tem-se o desafio de criar Programa Habitacionais que alcancem seus beneficiários. Outro desafio é que o planejamento habitacional seja articulado a outros setores como saneamento, transporte, meio ambiente, de modo a se implementar políticas urbanas integradas de maior impacto e resultados mais 
positivos. É claro que a segregação espacial predominante, aliada à baixa qualidade sócio-ambiental, reflete nas cidades a dissociação entre as políticas habitacionais, fundiárias e de planejamento urbano (FERNANDES, 2008).

Assim, falta um elemento que assegure a inter-relação entre os diversos planos de investimento setoriais e que oriente os programas habitacionais de modo a reduzir efetivamente o enorme déficit: o planejamento ambiental e urbano.

$\mathrm{Na}$ contextualização da provisão habitacional brasileira evidenciamos o acesso restrito à população de baixa renda durante diversos períodos. Também foi possível averiguar que nas políticas, planos e programas (PPPs) habitacionais direcionadas à população menos favorecida, a questão da localização das unidades é tratada de forma superficial, alocando as famílias em áreas periféricas e sem acesso à infraestrutura necessária. 
CAPÍTULO 2 AVALIAÇÃO AMBIENTAL 


\section{PLANEJAMENTO AMBIENTAL E URBANO EM PPPS HABITACIONAIS}

"Mudar a cidade é uma tarefa coletiva. Esta frase, em qualquer circunstância uma obviedade, adquire maior conteúdo de verdade sob um ângulo autonomista, de vez que não se tratará, então de impor soluções de cima para baixo, mas de construí-las democraticamente...[...] O planejamento e a gestão urbanos, por tudo isso em face de tudo isso, são, no sentido mais profundo possivel, políticos, ou um conhecimento técnico-científico mobilizado para alterar constelações de poder"

Souza, 2002.

Na história recente do planejamento urbano brasileiro observam-se tentativas diferentes de ordenamento do espaço. De acordo com Spinola e Abiko (2010), o crescimento populacional acelerado do século passado marcado pela urbanização desorganizada trouxe implicações profundas na forma e no funcionamento das cidades, como concentração de empregos distantes do local de moradia, ocupação de áreas de proteção ambiental, aglomerações populacionais em periferias sem acesso à infraestrutura contribuindo para a degradação sócio-ambiental do espaço urbano.

A questão central na organização da cidade nesses moldes é o embate entre as forças que a constroem - a produção do espaço é resultante das práticas e formas de apropriação do espaço por um determinado grupo social: as classes menos favorecidas ficam com as áreas menos disputadas (VILLAÇA, 2001).

Como já abordado, o déficit habitacional brasileiro é bem expressivo, concentrado na população de baixa renda. Essa realidade dos programas habitacionais brasileiros é, segundo Rolnik et. al (2010), fruto de políticas de planejamento e gestão urbana excludentes, baseadas em padrões de regulação urbanística voltados para setores restritos das cidades.

O planejamento de conjuntos habitacionais produzidos pelo setor público inicia-se com a identificação da demanda por habitações, sucedida pela seleção de área (ou de áreas) para a implantação e finalizando com a elaboração de projetos.

Nessa primeira fase, tende a não haver mudanças efetivas no meio, porém nela se definem as alterações ambientais que ocorrerão durante a construção e a ocupação do empreendimento. No Brasil, 
segundo Freitas et. al. (2001) a fase de planejamento tem sido realizada de forma insatisfatória, principalmente nos empreendimentos destinados à população de baixa renda.

Normalmente sobram os piores terrenos, que conduzem a impactos ambientais mais expressivos, ou áreas situadas nos limites urbanos, desprovidas da infra-estrutura necessária.

A segregação espacial predominante, aliada à baixa qualidade sócio-ambiental, reflete nas cidades a dissociação entre as políticas habitacionais, fundiárias e de planejamento urbano (FERNANDES, 2008).

O planejamento habitacional não tem nenhuma tradição no Brasil e, segundo Bonduki (2009), desde 1986 com a extinção do BNH, o setor habitacional passou por uma completa desarticulação e fragmentação institucional, perdendo a capacidade decisória e sofrendo com a redução dos recursos disponíveis para investimento.

Segundo Coelho (2002), a criação da Constituição Federal, em 1988, estabeleceu um marco importante no processo de redemocratização do País, seja pelos seus resultados, seja pelo envolvimento de movimentos sociais ou associações de classe em sua elaboração. A questão da moradia foi tratada na Constituição como competência comum à União, Estados e Municípios.

Entretanto, o planejamento na esfera local ressurge nos anos noventa, reforçado pelo intenso crescimento das cidades brasileiras, como importante instrumento para organização das ações governamentais, visando o bem-estar coletivo e a justiça social. Assim, o ordenamento territorial da cidade, mediante o planejamento, é competência do município.

A prática do planejamento urbano nos municípios visa facilitar a gestão municipal, alterar condições indesejáveis para a comunidade, assegurar a viabilização de propostas estratégicas, objetivos a serem atingidos e ações a serem trabalhadas. Para Rezende e Ultramari (2007) o planejamento é, de fato, uma das funções indispensáveis ao gestor municipal. Planejar a cidade é essencial. É o ponto de partida para uma gestão municipal efetiva, onde a qualidade do planejamento ditará os rumos para uma boa ou má gestão, com reflexos diretos no bem-estar da população (ANDRADE et. al., 2005).

O planejamento urbano brasileiro é regulamentado pela Lei no 10.157 em 10 de julho de 2001 Estatuto da Cidade, como conseqüência da Constituição Federal, após onze anos de tramitação no Congresso Nacional. Com a intenção de garantir um planejamento adequado econômica, social e ambientalmente, o Estatuto regulamenta os artigos 182 e 183 da Constituição Federal, que compõem o capítulo relativo à Política Urbana, regulamentando o uso da propriedade urbana em prol do interesse público, da segurança e do bem estar dos cidadãos, bem como do equilíbrio ambiental. 
O Estatuto da Cidade estipula como diretriz geral o planejamento das cidades e a distribuição espacial da população, das atividades econômicas do município e do território sob sua área de influência, buscando orientar a ação de todos os agentes responsáveis pelo desenvolvimento na esfera local.

Para o atendimento dessa diretriz, segundo Maglio (2005) apud Fabbro Neto e Souza (2009), é necessária a identificação de indicadores para acompanhar o desempenho da qualidade ambiental do meio natural, da capacidade de suporte da infraestrutura e dos serviços urbanos, que se viabilizam após a delimitação do escopo do que será estudado.

Desse modo, o gerenciamento municipal poderá integrar os padrões de qualidade ambiental e as demandas por equipamentos públicos e serviços urbanos com a regulação do consumo dos recursos naturais disponíveis.

O Estatuto da Cidade indica que as cidades devem ser tratadas como um todo, rompendo a visão setorial do planejamento urbano até então praticado. Além disso, evidencia que o planejamento deve ser entendido como processo construído a partir da participação permanente dos diferentes grupos sociais para se adequar às demandas locais e às ações públicas correspondentes (OLIVEIRA, 2001).

Nele também foram definidas as funções sociais da propriedade como competência da esfera municipal. Conforme o artigo 182 da Constituição Federal, o município é o ente federado principal na execução da política urbana. Portanto cabe aos municípios a definição das diretrizes do planejamento urbano e da habitação. Estas, por sua vez, são pré-requisitos para implantação de programas de moradia.

O Estatuto da Cidade orienta ainda as diretrizes e normas a serem fixadas pelo Plano Diretor Municipal, influenciando as decisões de uso do solo urbano.

O Plano Diretor assume a função de interferir no processo de desenvolvimento local, a partir da compreensão integradora dos fatores políticos, econômicos, financeiros, culturais, ambientais, institucionais, sociais e territoriais que condicionam a situação do Município.

De acordo com o Estatuto da Cidade, o Plano Diretor deve ser aprovado por lei municipal e se constitui em instrumento básico da política de desenvolvimento e expansão urbana. Como parte de todo o processo de planejamento municipal, o Plano Diretor deverá estar integrado ao plano plurianual, às diretrizes orçamentárias, ao orçamento anual e vinculado ao processo de planejamento, se existente (OLIVEIRA, 2001). Por isso, ele não é imutável, pode e deve ser continuamente revisto. 
Contudo, Hirata (2010) afirma que o plano diretor, que deveria dar base ás PPPs habitacionais demandadas pelo Governo Federal aos Estaduais e Municipais, apresenta limites, como o Plano Diretor de São Paulo, que não apresenta propostas concretas e operacionais. Dessa forma, os terrenos escolhidos, em grande parte das vezes, não estão em zonas especiais de interesse social $\left(\right.$ ZEIS $\left.^{10}\right)$.

A própria constituição diz ser facultativo ao poder publico municipal exigir do proprietário do solo urbano (mesmo que vazio ou subutilizado) o aproveitamento adequado ou que o imóvel cumpra sua função social. A existência do Plano diretor é lei, mas a punição para quem não cumpri-la é facultativa.

As questões que envolvem o planejamento urbano no Brasil tem sido fundamentalmente discurso, ocultando os problemas das maiorias urbanas e os interesses dominantes na produção do espaço urbano. (VILLAÇA, 1999).

Além disso, a degradação socioambiental do problema habitacional e urbano também é encoberta, alterando os conceitos de "plano" e "planejamento". O planejamento urbano no Brasil passa a ser identificado com a atividade intelectual de elaborar planos. Uma atividade fechada dentro de si própria, desvinculada das políticas públicas e da ação concreta do Estado. (VILLAÇA, 1999)

Para uma abordagem ambiental integrada em programas habitacionais de interesse social, a concepção da política habitacional deveria estar inserida na política urbana, mais global. Assim, segundo Freitas et. al. (2001), os programas habitacionais devem partir, desde seu planejamento, de uma ação coordenada entre órgãos municipais, incluindo diferentes esferas de governo, como estadual e federal, além do setor privado e organizações não-governamentais. A articulação entre as estratégias de produção habitacional e de acesso à terra urbana adequada é de suma importância para a integração das moradias nas cidades (CUNHA e BORGES, 2011).

Outro aspecto importante refere-se ao fato de que na prática urbana, grande parte das questões é, simultaneamente, social e ambiental, ainda que não sejam formuladas como tal.

Costa e Braga (2010) afirmam que desigualdade ambiental é uma das expressões visíveis da desigualdade social, ou seja, os segmentos mais pobres estão mais expostos a riscos ambientais em seus locais de moradia e de trabalho, bem como na localização de suas moradias na estrutura altamente diferenciada do espaço urbano.

\footnotetext{
10 Porções do território destinadas, prioritariamente, à recuperação urbanística, à regularização fundiária e à produção de Habitações de Interesse Social (HIS). (PDE, 2004: 123).
} 
De acordo com Santos (2004), o planejamento ambiental é compreendido como um planejamento de uma região, visando integrar informações, diagnosticar ambientes, prever ações e normatizar seu uso através de uma linha ética de desenvolvimento. Isso significa que o planejamento ambiental se faz necessário para alcançar o desenvolvimento sustentável, pois analisa as potencialidades e riscos essenciais à utilização dos recursos naturais para o desenvolvimento da sociedade.

Para a sociedade, a importância do planejamento ambiental deve-se ao seu funcionamento enquanto ação preventiva contra os possíveis problemas ambientais decorrentes do desordenamento da ocupação territorial da cidade. Nesse sentido, a ocupação planejada tem a função de beneficiar a população através do desaparecimento ou redução dos problemas ambientais (enchentes, inundação, etc).

Assim, as medidas de minimização de impactos ambientais deveriam ser pensadas em uma escala de ação ampla, que abarque de forma integrada a cidade, seu espaço circundante imediato e os mais distantes.

A dimensão ambiental do urbano é antes um campo em construção e disputa que uma definição acabada. A prática ambiental urbana ganha contornos complexos em uma realidade heterogênea como a brasileira, na qual as cidades convivem ao mesmo tempo com problemas típicos da pobreza e problemas relacionados a altos padrões de vida e consumo, como congestionamento de trânsito e poluição atmosférica (COSTA e BRAGA, 2010).

A forma como os recursos são utilizados obedece à lógica de valorização do capital no espaço urbano e reflete-se diretamente sobre a qualidade de vida das populações e do espaço urbano, reproduzindo desigualdades e conflitos.

O principal foco do conflito de interesses em torno das políticas ambientais urbanas é a tensão entre o uso público e privado dos recursos econômicos, sociais, culturais, bióticos e abióticos da cidade e de seu entorno.

Dentre tais conflitos, destacam-se aqueles relacionados à ocupação do solo. A ordenação do processo do uso e ocupação do solo urbano, atividade de competência municipal, deveria ser questão prioritária numa política de gestão ambiental.

Problemas como a precária disponibilidade de áreas, elevado preço da terra, loteamentos irregulares e clandestinos sem infraestrutura básica e equipamentos essenciais retratam o uso desigual e injusto do solo. 
De acordo com Pires (2007), a política urbana tem por finalidade a ordenação dos espaços habitáveis, visando à realização do desenvolvimento das funções sociais da cidade.

No entanto, a maioria dos municípios não demonstra estar preparada, tanto tecnicamente quanto institucionalmente para esse desafio. Assim, questões cruciais, como o desenvolvimento integrado do setor de transportes com o setor habitacional, esbarram em questões pontuais que poderiam ser tratadas de forma concentrada e coordenada.

A questão ambiental urbana, dada sua complexidade, raramente é tratada de forma unificada, mas encontra-se dividida entre vários setores do poder público. Geralmente o órgão responsável pelo uso e ocupação do solo não responde pelos transportes nem pelas áreas verdes. Assim, segundo Costa e Braga (2010), as políticas são implementadas de forma setorizada e há pouco diálogo entre os diferentes órgãos.

Burgess et.al. (1997) afirma ser necessário reconhecer que os problemas ambientais exigem uma responsabilidade simultânea do nível local, da cidade e da região. Neste sentido, ações de planejamento municipal envolvem o território municipal como um todo, considerando as interações entre a área urbana e o meio rural para a análise ambiental. De acordo com Sánchez (2006), é no momento da análise da viabilidade ambiental que os diferentes fatores serão contemplados, para que estejam de acordo com as premissas de um desenvolvimento sustentável.

Ferreira (1998) conclui que a política ambiental está desvinculada das demais políticas públicas e econômicas, não sendo considerada uma política social nem de desenvolvimento. Essa mesma lógica se reproduz no nível local, onde a política ambiental é pensada de forma dissociada das demais políticas econômicas, sociais e setoriais.

Com isso, grande parte das questões fundamentais de política ambiental, como o saneamento, o sistema de transportes e a regulação do uso e ocupação do solo, ficam a cargo de órgãos não integrados, dotados de lógicas distintas e atuação pontual. Entretanto, a questão não se resume apenas à falta de integração, mas envolve também, e principalmente, a existência de objetivos e lógicas contraditórias entre as diferentes políticas estabelecidas pelo poder público.

O papel dos novos instrumentos urbanísticos, a quantificação da necessidade de terras, a localização da habitação nas cidades, o impacto da produção habitacional nas cidades, são para Cunha e Borges, (2011) questões do planejamento habitacional que se articulam com outros instrumentos de planejamento urbano, como o próprio plano diretor, planos de saneamento, das leis de uso e ocupação do solo. 
O zoneamento urbano é, certamente, o mais difundido instrumento urbanístico e, também, o mais criticado, tanto por sua eventual ineficácia, quanto por seus efeitos infelizes (especulação imobiliária e segregação socioespacial). Segundo Agra Filho (2002), apesar das contribuições relevantes ao planejamento ambiental no Brasil, o zoneamento é ineficaz para reverter os processos determinantes das ocupações ambientalmente insustentáveis e insatisfatório na orientação da sustentabilidade ambiental para ocupações territoriais.

O espaço urbano, entretanto, tem um valor próprio: o valor da localização. A localização é fruto do trabalho social empregado necessariamente na produção da cidade inteira e se define pela capacidade que certo ponto do território oferece para relacionar-se com os outros pontos da cidade. Tal ponto é disputado pelas classes sociais que buscam ocupar as localizações mais valiosas da cidade, tanto para residência como para negócios. (VILLAÇA, 1999)

Para Rolnik org. et.al. (2010), produzir moradias adequadas em zonas consolidadas e bem localizadas é importante pois garante uma cidade com equilíbrio entre moradia e emprego, melhora o aproveitamento e a otimização da infraestrutura existente, enfrenta a demanda habitacional observando princípios democráticos e redistributivos, garante localização adequada para todas as classes sociais, principalmente para a população de baixa renda, minimiza a necessidade de deslocamentos e diminui os impactos ambientais decorrentes do processo de espraiamento urbano.

Para isto, é necessário aliar política urbana, habitacional e ambiental com programas voltados à regularização fundiária e à ocupação de áreas centrais e vazios urbanos.

Como apresentado anteriormente, há diversos efeitos negativos nas políticas habitacionais anteriores. O Programa Minha Casa Minha Vida deveria aprender com estas políticas e propor novas alternativas ao enfrentamento da demanda habitacional. Para isto, é preciso entender que a provisão habitacional não se resume a soluções quantitativas e que é necessário possibilitar uma boa localização para os mais pobres na cidade.

Existem diversos instrumentos urbanísticos e ambientais que facilitam o acesso a terra bem localizada, como o Estatudo da Cidade, os Planos Diretores, as Zonas Especiais de Interesse Social (ZEIS), permitindo a produção de moradias nos terrenos situados em zonas consolidadas e providas de infraestrutura. Entretanto a seleção de áreas adequadas para a provisão habitacional e para atender a demanda tem sido realizada de forma precária no Brasil. É comum, na fase de escolha de locais para instalação de conjuntos habitacionais, a indicação da área destinada à ocupação sem análise prévia de alternativas. 
A falta de preocupação de inserção física, jurídica, urbanística e social da população de baixo poder aquisitivo na cidade induz, dentre outras situações decorrentes, ao não-compromisso de geração de infra-estrutura e serviços públicos, além de desvincular do Poder Público sua gestão posterior (FREITAS et. al. 2001). O planejamento ambiental integrado deve ser a base para iniciar qualquer programa habitacional de interesse social, buscando mecanismos para articular infra-estrutura, qualidade social e ambiental, cobertura dos serviços sociais e de apoio ao desenvolvimento comunitário.

O processo de planejamento pode ser considerado mais importante que o próprio plano, pois este deve ser elaborado para que se torne exequível. O nível de profundidade dos estudos deve, segundo Fabbro Neto e Souza (2009), orientar a ação dos órgãos públicos. Deve haver complementaridade e integração entre os diferentes níveis hierárquicos de governo e entre políticas, planos e programas setoriais, respeito e adequação à realidade regional e local, em consonância com os planos e programas existentes.

O estatuto da cidade precisaria ser mais específico com relação às questões ambientais, para contribuir efetivamente com as alterações dos rumos dos impactos socioambientais observados nas cidades brasileiras.

Dessa forma, um dos instrumentos criados para o gerenciamento ambiental de planejamento urbano é a Avaliação de Impacto Ambiental

\section{AVALIAÇÃO DE IMPACTO AMBIENTAL E ESTUDO DE IMPACTO AMBIENTAL}

Até a década de 60, a avaliação das ações públicas e privadas baseava-se exclusivamente em critérios técnicos e econômicos, procurando maximizar os resultados esperados. Não havia nenhuma preocupação com os impactos ambientais e sociais decorrentes, o que acarretou no aumento da degradação dos recursos naturais e queda no nível de bem-estar da população.

Segundo Santos (1993), as cidades brasileiras de modo geral, tem características de uma urbanização corporativa, com tamanho urbano, modelo rodoviário, carência de infra-estruturas, especulação fundiária e imobiliária, problemas de transporte, extroversão e periferização da população. Dessa forma, os impactos ambientais associados ao processo de urbanização aumentaram muito no início do século XXI. 
A expansão periférica das cidades brasileiras e a implantação precária dos assentamentos criaram um quadro de grave degradação, trazendo um novo desafio ao poder público e à sociedade: a prevenção de novos impactos (MANSUR,2007).

Nesse contexto, segundo Oliveira e Bursztyn (2001) a Avaliação de Impacto Ambiental (AIA) surge como um instrumento do processo de planejamento com o objetivo de estimular a consideração de fatores ambientais na tomada de decisão, de modo que as ações implementadas sejam mais compatíveis com o meio ambiente.

A Resolução CONAMA 001/86 define impacto ambiental como “(...) qualquer alteração das propriedades físicas, químicas e biológicas do meio ambiente, causada por qualquer forma de matéria ou energia resultante das atividades humanas que, direta ou indiretamente, afetem: a saúde, a segurança e o bem-estar da população; as atividades sociais e econômicas; a biota; as condições estéticas e sanitárias do meio ambiente; a qualidade ambiental”.

A IAIA (International Association for Impact Assessment) define os seguintes objectivos da AIA:

- Assegurar que o ambiente seja explicitamente considerado e incorporado no processo de decisão sobre propostas de desenvolvimento;

- Antecipar e evitar, minimizar ou compensar os efeitos adversos significativos - biofísicos, sociais e outros relevantes de propostas de desenvolvimento;

- Proteger a produtividade e a capacidade dos sistemas naturais e dos processos ecológicos que mantêm as funções desses sistemas;

- Promover o desenvolvimento sustentável e que otimize o uso dos recursos e as oportunidades de gestão.

Para Coelho (2004), a compreensão de impactos ambientais como processo depende, principalmente, de se compreender a história não-linear de sua produção, o modelo de uso e ocupação do solo e os padrões internos de diferenciação. O que é considerado positivo para uma classe social pode não ser para outra.

Neste sentido, a Avaliação de Impacto Ambiental é um processo e um instrumento de avaliação que pode auxiliar na busca do desenvolvimento sustentável, incluindo também os impactos sociais e econômicos.

A incorporação de critérios ambientais e de sustentabilidade ao processo de planejamento implica uma integração maior do sistema de planejamento, propiciando elementos, por exemplo, para a identificação e avaliação de alternativas que possam se mais adequadas. 
Em 1987, O Relatório Brundtland ${ }^{11}$ identificou a integração de considerações ambientais nas políticas públicas como uma das chaves dos desafios institucionais deste século.

A definição da viabilidade ambiental está entre os objetivos da Avaliação de Impacto Ambiental - AIA, sendo incorporada no Brasil como instrumento da Política Nacional de Meio Ambiente pela Lei $n^{\circ}$ $6.938 / 81$.

Para Sánchez (2006), o conceito de viabilidade ambiental não é único. Um projeto pode ser viável sob determinados pontos de vista, como o atendimento a requisitos legais, por exemplo. No entanto, os impactos socioambientais de um projeto distribuem-se de maneira desigual.

Muitos países desenvolvidos, e também os em desenvolvimento, adotaram o processo de AIA como o procedimento para incorporar as questões ambientais (e sociais) nas atividades de planejamento e de tomada de decisão. A existência de um processo de estudo de impactos ambientais é, hoje, um critério utilizado para demonstrar que o ambiente (físico e social) está sendo considerado na implementação de empreendimentos, independentemente se esse processo é apenas um meio formal de legitimação ou um instrumento efetivo de negociação e mediação (EGLER, 2002).

A AIA é usualmente considerada como um processo pelo qual várias e diferentes opções devem ser estudadas de forma igualmente detalhada, até que uma opção possa ser feita após avaliação comparativa. A aplicação da 'Avaliação de Impacto' internacionalmente é muito abrangente, podendo envolver, segundo a Associação Internacional de Avaliação de Impacto (IAIA, 2002), desenvolvimento de projetos de sustentabilidade, avaliação tecnológica, avaliação de impacto na saúde, avaliação de impacto ecológico e de biodiversidade, sistemas de gerenciamento ambiental, avaliação de impacto fiscal econômico, avaliação de impacto demográfico, avaliação de impacto de gênero, avaliação de impacto social, auditoria ambiental, avaliação de risco, avaliação ambiental estratégica, avaliação de políticas de venda e planejamento de desastres naturais.

Contudo, algumas deficiências importantes têm sido identificadas, mesmo quando o processo de AIA é considerado implantado e utilizado adequadamente. Entre essas deficiências, a mais importante, segundo Thérivel et. al. (1992), Lee e Walsh (1992) é que o processo de AIA tende a ocorrer muito tarde no processo de planejamento e de desenho de um empreendimento. Assim, torna-se difícil assegurar que todas as alternativas possíveis e relevantes ao projeto sejam adequadamente consideradas.

\footnotetext{
${ }^{11}$ O Relatório "Nosso Futuro Comum", conhecido como Relatório Brundtland, foi elaborado pela Comissão Mundial sobre o Meio Ambiente e Desenvolvimento, e define desenvolvimento sustentável como "desenvolvimento que satisfaz as necessidades presentes, sem comprometer a capacidade das gerações futuras de suprir suas próprias necessidades". Estabelece a necessidade de uma nova relação "ser humano-meio ambiente" sem sugerir a estagnação do crescimento econômico.
} 
A AIA aplicada atualmente no Brasil ocorre durante o processo de licenciamento ambiental, limitado às etapas de aprovação de projetos de empreendimentos que contenham potencial significativo de impacto ambiental. Essa avaliação das decisões que antecedem as instalações de empreendimentos é feita por meio da elaboração de Estudo de Impacto Ambiental - ElA e Relatório de Impacto Ambiental - RIMA, conforme regulamentado pela Resolução do Conselho Nacional de Meio Ambiente - CONAMA 01/86.

A exigência da elaboração e apresentação de EIA/RIMA, como condição para a realização de grandes obras, ganha ainda mais força com a inclusão de artigo na Constituição Federal de 1988 determinando a realização de estudo prévio de impacto ambiental para a "instalação de obra ou atividade potencialmente causadora de significativa degradação do meio ambiente" (CF/1988, Art. 225, $\S 10$, inciso IV).

As normas de proteção ao meio ambiente se aplicam às cidades, possibilitando ações por parte do poder público no sentido de melhorar a qualidade de vida do meio urbano.

Segundo André et al.(1999) assinalam que, desde sua adoção, nos anos 1970, o Estudo de Impacto Ambiental (EIA) visa a estabelecer se um projeto é aceitável face aos impactos gerados sobre o ambiente, às possibilidades de atenuar tais impactos e aos benefícios sociais decorrentes de sua implementação. Desse modo, contribui para que o planejamento e a implementação de projetos e atividades levem em conta o meio ambiente.

Para Souza (2000), a AIA no país pode ser vista como um processo técnico e burocrático, não produzindo os efeitos desejados em termos ambientais nem atingindo seus objetivos.

Por ser atrelada ao processo de licenciamento ambiental, a aplicação da AIA ficou restrita à projetos específicos e atividades isoladas, em detrimento de uma perspectiva mais abrangente e estratégica de planejamento, como na elaboração de Políticas, Planos e Programas. Dessa forma, a AIA é incapaz de influenciar nas decisões estratégicas.

Oliveira e Bursztyn (2001) destacam que a AIA deve ser integrada ao processo de planejamento e não ser considerada uma experiência adicional para a obtenção de autorizações governamentais, que ocorre no final da preparação do projeto.

Outros problemas, como a não realização de AIA de políticas, planos e programas, assim como a falta de instrumentos que assegurem um monitoramento (BURSZTYN, 1994) evidenciam a necessidade de aumentar a efetividade do instrumento. Para Partidário (2002), a Avaliação Ambiental Estratégica ( $\mathrm{AAE}$ ) é uma prática recente que busca o aperfeiçoamento dos procedimentos de AIA. 
Partidário (2002) destaca que as atividades humanas deveriam modificar sua forma de atuar sobre o ambiente, reduzindo as degradações. As atividades devem ser pensadas, desenhadas e implementadas respeitendo os limites de capacidade dos recursos ambientais em oferecer serviços à sociedade sem necessariamente se esgotarem.

Nesse sentido, a Avaliação Ambiental Estratégica vem sendo apresentada como uma forma de lidar com muitas dessas limitações.

\section{AVALIAÇÃO AMBIENTAL ESTRATÉGICA}

Na situação atual de degradação do ambiente nas cidades brasileiras, praticamente todo novo processo de urbanização, significa um risco ambiental.

Mesmo com os avanços recentes na legislação urbana brasileira, como o caso da aprovação do Estatuto da Cidade, ainda não há detalhamento suficiente para contribuir, para a viabilização de um futuro desenvolvimento sustentável.

Os padrões ambientais que tratam de uso da terra foram sendo cada vez mais refinados por meio de um conjunto de resoluções do CONAMA - Conselho Nacional do Meio Ambiente. Entretanto, ainda existem limitações em um sistema de gerenciamento ambiental tão centralizado como o brasileiro.

Pensar o planejamento do território e a gestão ambiental de forma separada não faz sentido. Este tema foi largamente ponderado no Relatório Brundtland, focalizando a atenção nas relações entre o ambiente, a economia e a equidade social.

Logo, seria necessário avaliar cuidadosamente todo novo processo de urbanização. Esse aspecto ambiental é recomendado pela Resolução n. 237, de 19/12/1997 do CONAMA, incluindo o parcelamento do solo dentre as atividades sujeitas ao licenciamento ambiental (MANSUR, 2007).

O zoneamento ambiental inicialmente pensado pelas secretarias estaduais do meio ambiente, para orientar o uso e ocupação do território em nível regional, acabou tendo, segundo MANSUR (2007) sua aplicação prática restrita aos Planos de Manejo de Unidades de Conservação.

Como exposto, o Plano Diretor Municipal é o principal instrumento de planejamento urbano no Brasil, compreendendo a regulação do uso e ocupação de solo, e incorporando a participação de diferentes atores e a inserção da variável na tomada de decisão. Entretanto, por ser enquadrado na tipologia de plano, não passa por uma avaliação de impacto ambiental (FABBRO NETO, 2010 ). 
Dessa forma, os Planos diretores deveriam determinar a viabilidade de uso e ocupação do solo urbano, e o CONAMA regulamentar a necessidade de EIA a partir do Plano Diretor. O instrumento que vem para fazer a mediação entre estes dois níveis de regulamentação é o AAE (Avaliação Ambiental Estratégica).

A Cartilha intitulada "Como produzir Moradia bem localizada com os recursos do Programa Minha Casa Minha Vida", elenca instrumentos do Estatuto da Cidade que podem direcionar os investimentos na promoção imobiliária para terras "bem localizadas". Entre eles:

- Zonas Especiais de Interesse Social (ZEIS) em vazios urbanos;

- Parcelamento, Edificação e Utilização Compulsórios;

- Imposto Predial e Territorial Progressivo; (ROLNIK et al, 2010).

Entretanto, além dos instrumentos não considerarem a componente ambiental, eles raramente são aplicados pelos municípios.

Assim, conforme Fabbro Neto e Souza (2009), as possíveis ligações entre o Estatuto da Cidade e a AAE permitem que a componente ambiental seja considerada durante as ações de planejamento municipal.

A Avaliação Ambiental Estratégica - AAE, conhecida internacionalmente como SEA - Strategic Environmental Assessment surge na década de 80, associada ao reconhecimento das limitações práticas nas avaliações de impacto ambiental.

A AAE surge com a intenção de aprimorar as técnicas de AIA e permitir que a variável ambiental seja incorporada nos processo de tomada de decisão que antecedem as ações de empreendimento (FIGURA 7).

A AAE é a face da AIA que poderia exercer importante papel como instrumento de direcionamento do planejamento urbano, pois permite incluir numa fase inicial do processo o efeito que a implementação de determinadas ações estratégicas podem ter nos PPPs antes destes acontecerem.

Ela lida com impactos difíceis de serem considerados no nível de projeto, isto é, com impactos de múltiplos projetos que se inter-relacionam. É um instrumento que afeta a tomada de decisão num patamar onde outras alternativas podem ser consideradas e que incorpora considerações ambientais e de sustentabilidade nas decisões estratégicas.

THERIVEL (2004) define como ações estratégicas, ou seja, passíveis de uma AAE, as legislações; políticas econômicas; privatizações; planos de desenvolvimento integrados: nacional, regional/territorial, local/cidade; programas com projetos múltiplos; áreas de conservação; PPPs em 
escalas amplas, como transporte, resíduos sólidos; PPPs para a gestão de recursos específicos em escalas territoriais amplas, como gestão costeira, de águas e manejo florestal; PPPs para alcançar fins sociais, como desenvolvimento de empregos, acesso equitativo ao transporte, entre outros.

\section{FIGURA 7: ABORDAGENS OPERACIONAIS DA AVALIAÇÃO DE IMPACTO AMBIENTAL}

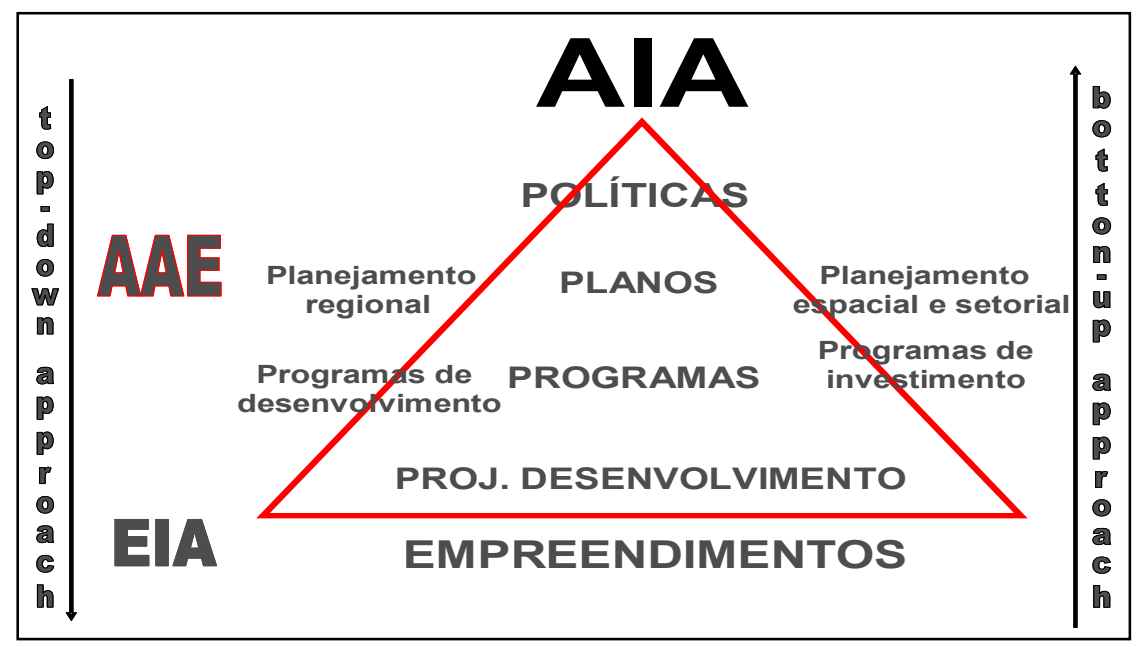

Fonte: Oliveira (2008)

A AAE, segundo Correia (2009), ajuda a assegurar que as ações estratégicas sejam implementadas de forma efetiva e que não ocorram efeitos inesperados dessas acções. Auxilia ainda os decisores a entenderem melhor o seu plano e facilita a participação pública no processo de tomada de decisão.

Segundo Thérivel (1992), a AAE pode ser entendida como "um processo sistemático, formal e abrangente de avaliação dos impactos ambientais de uma política, um plano ou um programa e de suas alternativas, incluindo a preparação de um relatório escrito contendo os resultados da avaliação, que devem ser usados no processo de tomada de decisão".

Uma definição mais simples para a AAE é a de que representa o processo de avaliação ambiental de políticas, planos e programas - PPPs (Quadro 2).

Entre as diferentes definições de Políticas, Planos e Programas podemos considerar a adotada por Sadler (1996) apud Partidário (2002) como:

- Política: uma direção que o governo está ou estará adotando, apoiada por juízos de valor que orientem seus processos de tomada de decisão". 
- Plano: "estratégia composta de objetivos, alternativas e medidas, incluindo a definição de prioridades, elaborada para viabilizar a implementação de uma política"

- Programa: agenda das propostas, instrumentos e atividades necessárias para implementar uma política, podendo estar ou não integrada a um Plano".

QUADRO 2: AVALIAÇÃO AMBIENTAL DE POLÍTICAS, PLANOS, PROGRAMAS E PROJETOS.

\begin{tabular}{|c|c|c|}
\hline Nível de Decisão & Objeto de Avaliação & Instrumento \\
\hline Política & $\begin{array}{c}\text { Visão, objetivos globais, prioridades e } \\
\text { intenções de desenvolvimento }\end{array}$ & AAE \\
\hline Plano & $\begin{array}{c}\text { Conceito de desenvolvimento, linhas } \\
\text { e propostas de ação, modelos de } \\
\text { ocupação do território }\end{array}$ & AAE \\
\hline Programa & $\begin{array}{c}\text { Conjunto coerente de ações } \\
\text { programáticas de investimento e } \\
\text { desenvolvimento }\end{array}$ & EIA \\
\hline Projeto & Ações concretas de desenvolvimento \\
\hline
\end{tabular}

Fonte: Baseado em Partidário (2003) apud Teixeira (2008).

Para a presente pesquisa, empregamos uma definição mais ampla, utilizada por Sadler e Verheem (1996) como: “AAE é um processo sistemático para avaliar as conseqüências ambientais de uma política, plano ou programa, de forma a assegurar que elas sejam integralmente incluídas e apropriadamente consideradas no estágio inicial e apropriado do processo de tomada de decisão, juntamente com as considerações de ordem econômicas e sociais."

Dessa forma, vincula-se o crescimento econômico com o meio ambiente relacionando a $A A E$ com a noção de desenvolvimento sustentável que, segundo Veiga (2006), procura vincular estreitamente pelo menos três âmbitos: o dos comportamentos humanos, econômicos e sociais; o da evolução da natureza; e da configuração social do território.

Segundo a IAIA (2002) a AAE deve pautar-se por ser:

- Integrada: deve explicitar o relacionamento entre os aspectos sociais, económicos e biofísicos;

- Orientada para a sustentabilidade: facilitar a identificação e o desenvolvimento de opções e propostas alternativas que sejam mais sustentáveis;

- Focada: deve concentrar-se nos efeitos ambientais significativos e nos fatores-chave, ou seja, nos aspectos que necessitam ser considerados no processo de decisão;

- Verificável: Submetida à avaliações independentes e mensuráveis. 
- Participativa: deve fornecer oportunidades para informar e envolver o público interessado;

- Iterativa: deve incorporar as lições apreendidas através do ciclo de vida das propostas;

Segundo Thérivel e Partidário (1996), Sadler e Verheem (1996) e Lee e Walsh (1992) há duas razões principais para inserir a AAE na agenda política e ambiental atual.

A primeira, como já mencionado, é a capacidade potencial que esse processo tem para superar as deficiências técnicas identificadas no processo de AIA.

A segunda é o papel que pode desempenhar na promoção do desenvolvimento sustentável. Assim, se o desenvolvimento sustentável é uma prática a ser alcançada pela integração das dimensões ambientais, sociais e econômicas no processo de tomada de decisões, o processo de AAE pode desempenhar um papel decisivo para essa integração, atuando como um processo de coordenação dentro dos diferentes níveis das atividades de planejamento governamentais (EGLER, 2002).

Para Partidário (2002), dentro do conceito amplo de AIA, a AAE é um instrumento que gerencia os diferentes interesses envolvidos, influenciando as estratégias de ações apoiadas em políticas, planos e programas - PPPs governamentais. Ou seja, nos níveis mais estratégicos de decisão das Políticas, Planos e Programas de intervenção estatal, sejam setoriais, regionais, ou áreas programáticas. Desse modo, a AAE pode apontar as prioridades sob o enfoque das conseqüências ambientais, atuando de maneira prévia à tomada de decisão e direcionando para um desenvolvimento mais sustentável. 0 caráter prévio garante a possibilidade de modificações e alternativas nas estratégias de ação.

A AAE é um instrumento de caráter político e técnico relacionado com conceitos e não com atividades específicas em termos de concepções geográficas e tecnológicas (MMA, 2002). É um instrumento de apoio à decisão que se constitui como um processo sistemático de identificação, análise e avaliação prévia de impactos de natureza estratégica (PARTIDÁRIO, 2006).

Desse modo, a adoção da AAE pode ser considerada uma forma de garantir que a noção de sustentabilidade esteja permeando o processo decisório, desde o mais alto nível da tomada de decisão até o estágio de projetos.

Portanto, não deve ser confundida com a AIA de grandes projetos, que envolvem tipos de atividade poluidora e afetam determinadas áreas, nem com relatórios de qualidade do meio ambiente nem, ainda, com iniciativas de planejamento que incorporem questões ambientais em suas formulações, mas cujas opções fundamentais não tenham sido objeto de avaliação segundo critérios e objetivos ambientais (TEIXEIRA, 2008).

A intenção é de que, para ter efeito no processo de formulação de possíveis PPPs, a AAE atue sobre a formulação do problema e não sobre o seu resultado, considerando os aspectos relevantes e 
procurando influenciar nas prioridades da tomada de decisão. O impacto que deve ser avaliado, de acordo com Teixeira (2008) procede das intenções de desenvolvimento, comumente traduzidas em uma perspectiva de uso do território, com ações planejadas segundo um modelo econômico e social, metas e objetivos definidos a partir de uma acepção temporal, e sugestão das possíveis opções para a consecução das referidas metas e objetivos.

Esse aspecto de AAE está relacionado à dimensão do sentido atribuído a PPP. Isso porque a diferença entre política, plano e programa não é muito clara. Para Wood \& Djeddour (apud Thérivel \& Partidário, 1996), a política pode ser considerada como uma intenção (inspiração) e orientação para a ação, o plano como o estabelecimento de objetivos coordenados para a implementação da política, e o programa como o estabelecimento de projetos em uma área específica. No entanto, na prática, essa seqüência pode variar de acordo com o contexto do sistema de planejamento do país.

De qualquer forma, o importante é considerar que PPP representa uma hierarquia do processo de planejamento seguindo a seqüência:

Política

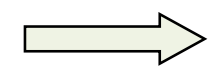

Plano

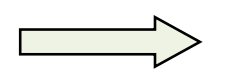

Programa

Projeto

O ideal seria que cada projeto fosse parte de um programa, cada programa um componente de um plano, e assim por diante, até o mais alto nível do processo de planejamento. Mas na prática não funciona desse modo. No entanto, para atender a seus propósitos, a AAE deve ser aplicada para cada política, plano ou programa, independentemente da presença ou ausência dessas hierarquias na composição da cadeia de planejamento (EGLER, 1998).

Partidário (2006) afirma ainda que, nos casos de planos e programas, o objeto da AAE deverá focalizar os impactos resultantes da estratégia de desenvolvimento, representados pelo conjunto de ações, e nunca pelos impactos resultantes de cada uma das ações que constituem o plano ou programa (esses impactos resultantes das ações individuais poderão ser objeto de avaliações ambientais específicas). Considerar os impactos estratégicos compreende avaliar os impactos ecológicos, físicos, sociais, culturais e econômicos.

Nesse sentido, ao implementar a AAE nos estágios anteriores de formulação de políticas, planos e programas, é possível incorporar considerações e critérios ambientais, minimizando significativamente os impactos ambientais dos projetos e, de acordo com Egler e Agra Filho (2004), reduzindo os respectivos custos das medidas mitigadoras necessárias.

A AAE está sendo considerada como uma forma de avaliar os impactos que não são devidamente considerados no nível de projetos, sendo essa capacidade de superar algumas limitações identificadas no processo de AIA, apontada como uma justificativa para sua crescente implementação. 
Isso porque, segundo Oliveira e Bursztyn (2001) a AAE pode incorporar questões ambientais de forma intrínseca no planejamento, influenciando o contexto no qual as decisões são tomadas, e considerando alternativas e medidas de mitigação que vão além dos limites de projetos individuais.

Desse modo, a AAE considera os impactos cumulativos e sinérgicos que, a princípio, poderiam ser considerados pouco significativos. Entretanto, se as ações que causam esses impactos forem analisadas de forma estratégica e do ponto de vista ambiental, é possível detectar antecipadamente os possíveis efeitos positivos e negativos sobre o meio ambiente e reajustar essas ações.

De acordo com Thérivel e Paridário (1996), a AAE pode ser aplicada para três principais tipos de ações:

- PPPs setoriais - relacionadas com setores específicos (ex: extração mineral, energia, turismo);

- PPPs territoriais - que abrangem todas as atividades de uma dada área (ex: planos regionais de uso da terra ou de desenvolvimento); e

- ações ou políticas que não estimulam a implementação de projetos, mas que podem ter impactos ambientais significantes (ex: práticas agrícolas, adoção de novas tecnologias e privatizações de recursos naturais).

O principal problema com essa tripla contextualização para aplicação do processo de AAE é a natureza integrada desses três tipos de ações apontadas, uma vez que, segundo Egler (1998), é impossível discutir uma política, plano ou programa setorial sem ligá-los ao território onde serão implantados, e também e também com os contextos ou ideologias políticas, sob as quais o PPP foi criado.

O mesmo é válido para a dimensão geográfica, uma vez que é impossível considerar o uso de uma determinada área sem analisar as atividades setoriais que serão desenvolvidas nela e ao redor dela.

A AAE deve ajudar a identificar a melhor opção para a estratégia de ação dos PPPs, selecionando e analisando diferentes opções, encontrando demandas, minimizando danos e oferecendo opções para administrar essas possibilidades. Basicamente, a AAE ajudaria a expandir o foco do tomador de decisão para incluir questões que estão além de sua área principal, como a sustentabilidade ambiental, por exemplo (FABBRO NETO, 2010).

Para Thérivel \& Partidário (1996), a efetividade da AAE é maior quando é implementada desde as etapas iniciais do planejamento, antes que alguma decisão importante seja tomada. Se for realizada nas fases finais, ela pode tornar mais lento o planejamento de PPP, devido ao levantamento de problemas ambientais em um estágio em que a maioria das decisões já foram tomadas. Nesse caso, Oliveira e Bursztyn (2001)) alegam que o tomador de decisão terá de considerá-la importante, o que 
pode ser muito difícil se o PPP for objeto de forte pressão política ou exigir um tempo de estruturação muito longo.

Na Figura 8, a inserção das etapas da AAE na estrutura do processo decisório permite a conexão com a variável ambiental. As setas indicam o sentido da agregação da informação e de estas contribuem para as etapas posteriores. Pode-se perceber a importância e a necessidade de integração entre as informações geradas para identificar alternativas mais sustentáveis pela AAE.

FIGURA 8: INTEGRAÇÃO DO PROCESSO DE AAE COM A ESTRUTURA DE DECISÃO.

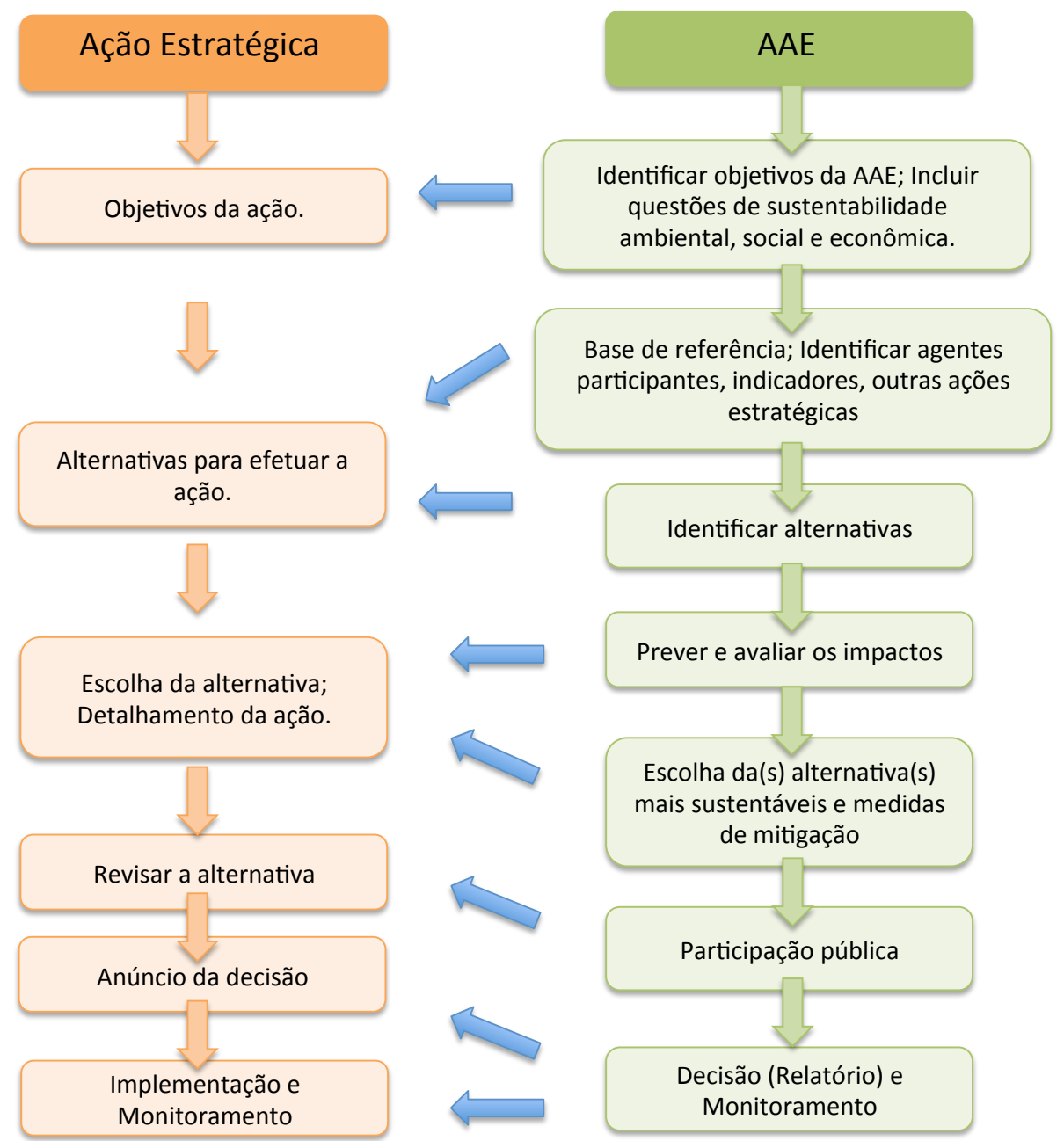

Fonte: Baseado em Thérivel, 2004

Segundo Thérivel (2004), a estratégia de ação pode ser alterada de acordo com o resultado da $A A E$, propondo-se diferentes objetivos e alternativas, além de diferentes maneiras de implementá-las. 
Para a realização de uma AAE efetiva, é necessária a participação pública. O envolvimento popular na tomada de decisão durante a realização da AAE traz vantagens à estrutura local, ao conhecimento e à pesquisa, propicia liderança com maior sociabilidade e aceitação política das decisões.

A participação estimula a apropriação das decisões e a transformação das estratégias em ações mais acessíveis.

O processo da AAE funciona melhor quando há grande integração de interesses e propostas. $\mathrm{O}$ público pode ajudar a estabelecer os objetivos, metas e indicadores e tornar as informações mais compreensíveis, tornando as questões ambientais mais próximas da realidade local. Desse modo, contribui para a identificação de opções sustentáveis e politicamente aceitáveis, além se selecionar alternativas e medidas mitigadoras, garantindo a eficiência na implementação das ações (FABBRO NETO, 2010).

A AAE denominada integrada estabelece um elo de ligação entre as etapas decisórias do planejamento com as etapas da AAE, possibilitando aos agentes responsáveis pela PPP se informar a respeito dos resultados da AAE e utilizar as análises para tomar suas decisões (JOÃO, 2005). A Figura ilustra a forma como os modelos integrados influenciam as etapas da estratégia.

Entretanto, existe o fato de, muitas vezes, as Políticas, Planos e Programas (PPPs) se desenvolverem de uma forma pouco compreensível para o grande público.

A criação de PPPs é um processo complexo e os tomadores de decisão irão decidir sobre as implementações e, conseqüentemente, sobre os impactos ambientais, os quais irão depender de seus próprios interesses. Aí está uma das importantes tarefas da participação pública: a reversão desse processo, centrado nos tomadores de decisão.

Chegar a um consenso com a participação da sociedade é um grande desafio, identificado por Nicolaidis (2005) apud Oliveira et. al. (2009) como uma falha na eficácia das avaliações de impacto, visto que o suporte à decisão compartilhada é uma das finalidades das AIAs.

\section{OBJETIVOS DA AAE}

Wood e Djeddour, 1992 apud Teixeira (2008) destacam como objetivo principal da AAE avaliar os impactos ambientais de alternativas concretas, antes de compromissos mais formais sobre a formatação da PPP e localização dos projetos necessários para implementá-la. Segundo Correia (2009), os principais objetivos da AAE são contribuir para um processo de decisão ambiental e sustentável; 
melhorar a qualidade de políticas, planos e programas; fortalecer e facilitar a AIA de projetos; promover novas formas de tomar decisão.

Tendo como objetivo a inserção da variável ambiental na elaboração das PPPs, avaliando sua viabilidade ambiental e melhorando suas estratégias de forma a alcançar a sustentabilidade ambiental, a AAE pde modificar os objetivos da ação estratégica (PIZELLA, 2010)

João (2005) apud Pizella (2010) apresenta como exemplo o caso de uma estratégia de transporte que tinha como objetivo inicial garantir o tráfego de todas as formas de transporte e melhorar a economia regional minimizando os impactos ambientais derivados do uso de veículos motorizados. No entanto, foram encontradas algumas contradições nesta proposta, que poderia conduzir ao aumento do número de veículos sem garantir necessariamente o acesso da população aos meios de transporte, além de ocasionar problemas ambientais. A elaboração de uma AAE conduziu à reformulação deste objetivo, que passou a ser o aumento da acessibilidade e a redução da necessidade de utilizar veículos motorizados de transporte. Assim a AAE contribuiu para mitigar os possíveis impactos negativos e maximizar os positivos.

Thérivel (1999) afirma que a preservação e a melhoria da qualidade ambiental, o uso racional dos recursos naturais, a garantia de regulamentação de convenções ambientais, a proteção da saúde humana e a integração das questões ambientais no planejamento também são alguns objetivos da AAE.

Dessa forma, podem ser identificados os seguintes objetivos da AAE:

- Garantir a integração das considerações ambientais, sociais e econômicas nos processos de planejamento e formulação de políticas;

- Identificar os impactos e avaliar e comparar as opções e alternativas de desenvolvimento;

- Contribuir para a identificação de opções estratégicas e de alternativas mais sustentáveis de desenvolvimento;

- Contribuir para a tomada de decisão mais sustentável em termos ambientais, sociais e econômicos;

. Facilitar a consideração dos impactos ambientais cumulativos;

- Melhorar as condições de realização da AIA de projetos, contribuindo para a eficiência do processo de licenciamento ambiental (FIGURA 9). 
FIGURA 9: CONTRIBUIÇÃO DA AAE PARA EIA.

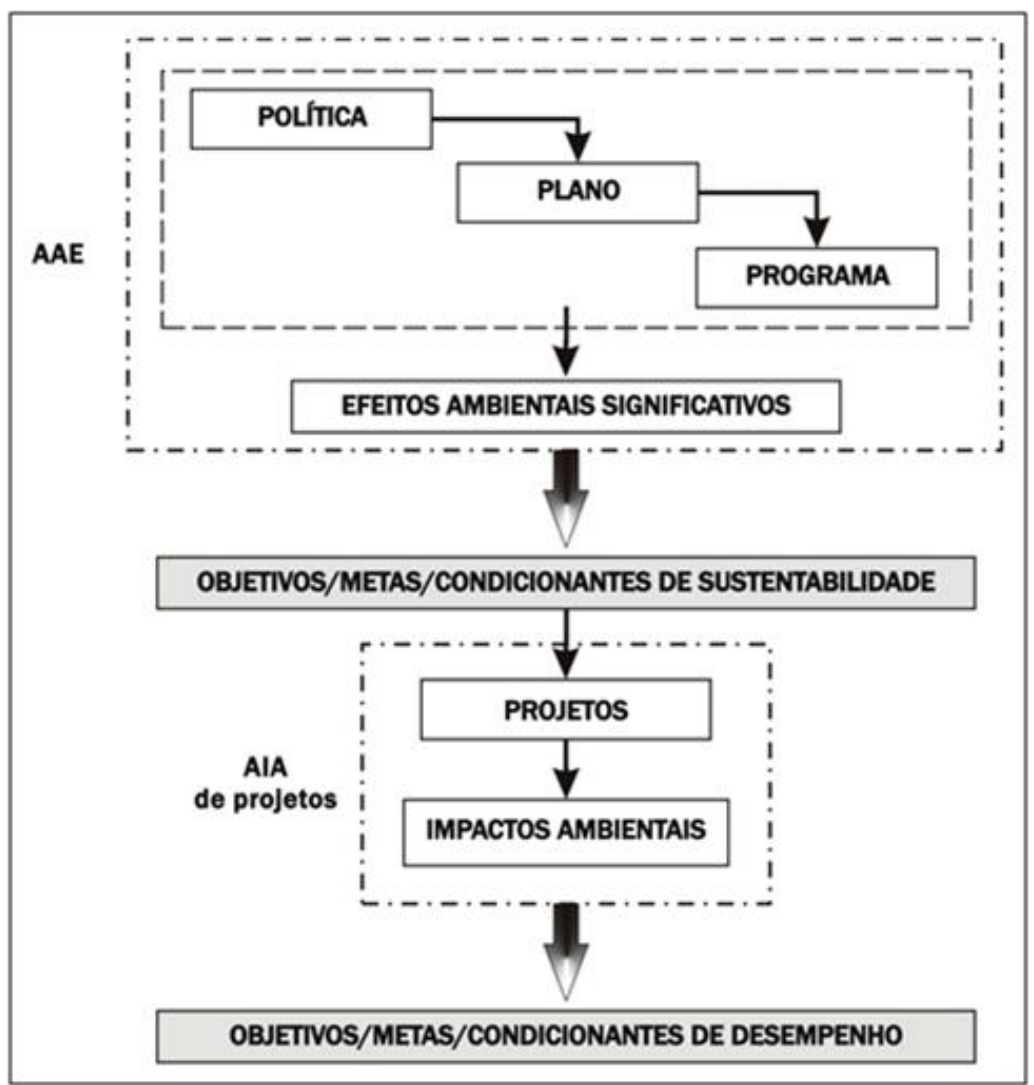

Fonte: Oliveira et. al. 2009.

Segundo Partidário (2012), a AAE, numa abordagem de pensamento estratégico, visa três objetivos concretos:

1. Encorajar a integração ambiental e de sustentabilidade (incluindo os aspetos biofísicos, sociais, institucionais e econômicos), estabelecendo as condições para acomodar futuras propostas de desenvolvimento;

2. Acrescentar valor ao processo de decisão, discutindo as oportunidades e os riscos das opções de desenvolvimento e transformando problemas em oportunidades;

3. Alterar mentalidades e criar uma cultura estratégica no processo de decisão, promovendo a cooperação e o diálogo institucionais e evitando conflitos.

Assim, de acordo com Partidário (2006) apud Teixeira (2008), a AAE acrescenta valor à decisão estratégica por integrar questões ambientais e de sustentabilidade; discutir as opções quando ainda estão abertas; promover a cooperação institucional e, assim, antecipar e identificar os potenciais conflitos; transformar problemas em oportunidades e apostar em soluções favoráveis a todos. 
Porém, para que a função de facilitadora da sustentabilidade da AAE seja cumprida, é preciso que o processo de planejamento tenha adotado a definição estratégica de sustentabilidade no contexto de integração das políticas setoriais.

A eficácia da AAE está ligada à sua capacidade de se adaptar e integrar aos processos de formulação e decisão associados às PPP (TEIXEIRA, 2008). O seu foco são as estratégias, devendo atuar quando a formulação de opções estratégicas ainda esteja em aberto, garantindo a consecução dos objetivos almejados.

A AAE aplica-se às componentes estratégicas dos processos de decisão em políticas públicas, planos e programas setoriais de desenvolvimento, planos e programas de desenvolvimento territorial e também à grandes projetos estruturais de investimento que tenham objetivos estratégicos de longo prazo (como novos aeroportos internacionais, produção de novas formas de energia).

Segundo Pardidário (2012), a AAE tem sido amplamente promovida por agências internacionais de desenvolvimento. Mais do que avaliar propostas de intervenção, a AAE serve como um importante instrumento para ajudar a enfrentar desafios de desenvolvimento originados por:

- Adaptação e mitigação às alterações climáticas;

- Erradicação da pobreza e superação das desigualdades sociais e regionais;

- Manutenção e valorização dos valores da biodiversidade, dos serviços dos ecossistemas e do bem estar humano;

- Coesão social e territorial;

- Promoção do potencial de desenvolvimento regional;

- Inovação e diversidade cultural das populações;

- Promoção da qualidade ambiental, da paisagem e do património cultural, e do uso sustentável dos recursos naturais. (PARTIDÁRIO, 2012)

Cabe destacar que a AAE não tem como objetivo substituir o EIA, que possui suas atribuições específicas, mas sim complementá-lo e antecedê- lo por meio de um planejamento ambiental prévio. No estado da Califórnia, nos EUA, por exemplo, a AAE já permitiu que projetos decorrentes do planejamento não necessitassem de avaliações muito detalhadas (JOÃO, 2005) 


\section{DIFERENÇAS ENTRE EIA E AAE}

Uma das maiores justificativas relacionadas com a necessidade de se implementar a AAE baseiase nos problemas e limitações do EIA.

Uma dessas limitações é o tempo. Freqüentemente os EIA precisam ser feitos rapidamente em função das restrições orçamentárias e pelo limite de tempo para serem submetidos às instâncias competentes. Este fato limita a quantidade de dados a serem levantados e a qualidade da análise que é feita.

Sendo realizada no início do processo de decisão, a AAE pode auxiliar na avaliação adequada de alternativas, na consideração de impactos cumulativos, na consulta abrangente ao público, e num modo mais pro-ativo do que reativo sobre a decisão em projetos individuais.

A racionalidade da AAE está associada a sua orientação mais estratégica, o que a diferencia da prática da EIA. A palavra "estratégica" determina um caráter mais flexível e diferente para avaliar preventivamente as intenções de desenvolvimento de longo prazo e, assim, melhorar a perspectiva em propostas e projetos de desenvolvimento.

De acordo com Partidário (2006), a AAE não deve ser confundida com a AIA de projetos (EIA), que se preocupa com a verificação dos efeitos após a formulação das propostas de intervenção e confunde estratégia com solução.

A distinção entre AAE e EIA pode ser entendida de uma maneira simples (QUADRO 3). No EIA, se conhece o que se quer avaliar - já está tomada a decisão sobre ações que devem ser adotadas para a realização dos objetivos que foram estabelecidos. A abordagem é de avaliação dos impactos ambientais associados à decisão adotada.

Já na $A A E$, o que se tem é uma idéia, uma intenção do que se deseja, sem a certeza sobre o que vai ser feito. $O$ instrumento ajuda na percepção dos valores e dos usos potenciais dos recursos, segundo a ótica dos diferentes setores interessados. Contribui para o esclarecimento dos diferentes objetivos que possam ser pensados, facilitando uma solução que reflita os diferentes interesses e possibilitando o planejamento integrado das opções.

A AAE ajuda a dar às questões ambientais uma importância similar àquela que é dada a outros aspectos na tomada de decisão. Isso estimula a articulação dos objetivos ambientais com os objetivos sociais e econômicos. Também considera mais os impactos cumulativos do que AIA em nível de projeto, 
devido à sua posição nos estágios iniciais do processo de tomada de decisão e por considerar uma ampla diversidade de ações sobre uma grande área geográfica ou um setor da atividade econômica;

QUADRO 3: PRINCIPAIS DIFERENÇAS ENTRE EIA E AAE.

\begin{tabular}{|c|c|}
\hline EIA & AAE \\
\hline Instrumento de Licenciamento Ambiental. & Instrumento de Planejamento Ambiental \\
\hline Avalia os efeitos de um empreendimento proposto & $\begin{array}{l}\text { Avalia os efeitos de uma política, plano ou programa, ou os } \\
\text { efeitos do ambiente nas condições apresentadas às atividades }\end{array}$ \\
\hline É imediato, operacional, descritivo, quantitativo & É conceitual, visionária, estratégica, qualitativa \\
\hline Recortes territoriais reduzidos (âmbito do Projeto) & $\begin{array}{l}\text { Recortes territoriais amplos (nacional, estadual, regional, } \\
\text { municipal) }\end{array}$ \\
\hline Tem base de dados mais concreta, mais real & Trabalha com perspectivas, intenções \\
\hline Avalia uma alternativa particular, específica & Foca nas alternativas, oportunidades. \\
\hline Prevê e avalia possíveis resultados & Determina opções e prevê possíveis resultados para cada opção \\
\hline $\begin{array}{l}\text { As alternativas têm localização determinada, desenho, } \\
\text { construção e operação }\end{array}$ & $\begin{array}{c}\text { É abrangente nas alternativas territoriais, política, tecnológica, } \\
\text { econômica, legal }\end{array}$ \\
\hline Atém-se a restrições legais & Busca padrão de sustentabilidade (critérios e objetivos) \\
\hline $\begin{array}{l}\text { Participação social apenas nas fases de licenciamento do } \\
\text { projeto }\end{array}$ & Participação social em todas as etapas de planejamento. \\
\hline Observa impactos específicos de projeto & $\begin{array}{l}\text { Cria uma estrutura para medir os impactos e os benefícios de } \\
\text { PPPs }\end{array}$ \\
\hline $\begin{array}{l}\text { Tem uma perspectiva restrita e um alto grau de detalhe; produz } \\
\text { resultado detalhado }\end{array}$ & $\begin{array}{l}\text { Tem uma perspectiva ampla e um baixo grau de detalhe para } \\
\text { proporcionar uma visão geral da estrutura; sua resposta é mais } \\
\text { genérica }\end{array}$ \\
\hline É mais técnico e restrito a acomodar decisões já tomadas & $\begin{array}{c}\text { É fundamental ao processo decisório e o vínculo com o } \\
\text { planejamento }\end{array}$ \\
\hline $\begin{array}{l}\text { Trabalha-se com a perspectiva de execução do objeto em } \\
\text { análise, desde que assegurada a viabilidade ambiental }\end{array}$ & O objeto analisado pode não se concretizar \\
\hline A perspetiva é de execução e de curto e médio prazo & A perspetiva é estratégica e de longo prazo \\
\hline $\begin{array}{l}\text { A finalidade é conhecer como será o futuro, prever os } \\
\text { potenciais impactes, baseado em previsões de eventos } \\
\text { passados }\end{array}$ & $\begin{array}{l}\text { Não se procura saber o futuro, a finalidade é ajudar a construir } \\
\text { um futuro desejável }\end{array}$ \\
\hline
\end{tabular}

Fonte: Adaptado de Thérivel (1994) e Partidário 2012 
Além disso, a AAE pode aperfeiçoar a identificação de medidas de mitigação para impactos propostos nos EIA, principalmente devido à consideração de alternativas, de forma mais ampla; e em alguns casos, poderia tornar a AIA redundante, se os impactos fossem examinados suficientemente em nível de plano ou programa (OLIVEIRA E BURSZTYN, 2001).

As decisões estratégicas tomadas a partir do EIA para projetos específicos, em geral, conduzem a uma variedade limitada de alternativas e medidas de mitigação, pois considera apenas os impactos diretos da ação de desenvolvimento, deixando de lado uma série de outros impactos possíveis.

\section{ETAPAS}

Ainda que adotem princípios coincidentes, existem diversas metodologias para a realização de $\mathrm{AAE}$, como as adotadas pela Comissão Econômica Européia, Plataforma SEAN e Ministério do Meio Ambiente brasileiro (TEIXEIRA, 2008). Para a presente pesquisa foi utilizada a estruturação de procedimentos técnicos adotada pelo MMA (2002) e defendida por Partidário (2002).

Segundo os autores, a elaboração de uma AAE deve conter as seguintes etapas sequenciais básicas:

. 1aㅗ Screening - Seleção de propostas de decisão estratégica;

. 2a Timing - Estabelecimento dos prazos;

. 3a Scoping - Definição do conteúdo da avaliação;

. $\quad$ 4a Avaliação dos impactos estratégicos;

. 5a Documentação e informação;

. 6a Revisão;

. 7a Decisão e

. $\quad$ 8a Acompanhamento da implementação da decisão estratégica.

Na primeira etapa, chamada de screening, estabelece-se os propósitos da AAE.

O primeiro passo no processo de AAE é estabelecer o contexto, a seleção inicial (screening), para decidir se é apropriada e relevante a realização de uma AAE no desenvolvimento de uma PPP. Deve ser feita pela seleção de propostas de decisões estratégicas e seguida pelo estabelecimento de prazos para sua realização - chamado de timing (segunda etapa).

A terceira etapa - scoping, delimita o escopo dos estudos e se inicia com a definição de objetivos e metas. Esta etapa define os dados e informações a serem levantados e os indicadores passíveis de serem selecionados. 
A seleção apropriada de indicadores é influenciada pelo tipo de informação disponível no momento e aqueles que serão úteis para a prática futura. Isso se aproxima da coleta de dados de bases de referência - as chamadas baselines, ou base ambiental, que contêm informações sobre o ambiente prévio à implementação dos planos de gestão (FABBRO NETO, 2010). A base de referência ambiental têm o objetivo de fornecer as informações necessárias para as etapas seguintes do EIA, tais como a previsão e avaliação dos impactos ambientais. De acordo com Sanchez (2006) as funções da baseline seriam:

- fornecer informações necessárias para a identificação e previsão dos impactos;

- contribuir para a definição de medidas mitigadoras, compensatórias e programas de monitoramento;

- estabelecer uma base de dados para futura comparação com a real situação, em caso de implementação do projeto.

No contexto de integração, a Base de Referência garante um balizamento com ênfase específica nos aspectos ambientais. Se for definida previamente, pode estar associada a outros instrumentos e a outras áreas, garantindo a informação (OLIVEIRA, 2008)

Essa etapa também influência em quais previsões de impactos serão feitas e o sistema de monitoramento estabelecido. Assim será possível identificar os atores envolvidos - chamados de stakeholders, e formas de participação.

É nesse momento que se determina a escala das informações ambientais. A AAE precisa gerar para os tomadores de decisão informações relevantes cujas atualizações frequentes sejam viáveis. Assim, um mapeamento em escala adequada é fundamental A escala espacial permite a representação dos mais relevantes processos ambientais e indicações de uso do solo.

Tanto as definições da necessidade ou não da AAE (screening) como do termo de referência (scoping), devem ser adequadas ao contexto e aos objetivos propostos, com respaldo da base de referência e das listas previamente definidas (OLIVEIRA, 2008).

A quarta etapa é a denominada avaliação dos impactos estratégicos, determinando do tipo e magnitude dos impactos ambientais esperados para a implementação dos objetivos, a partir da análise das bases de referência. A previsão de impactos ajuda a determinar como esse problema pode ser administrado e pode sugerir medidas mitigadoras.

A AAE deve garantir que a estratégia adotada não exceda a capacidade de suporte do meio, evitando os impactos irreversíveis. Isso envolve a identificação de cada limite, através do diagnostico 
ambiental da área. A realização do diagnóstico torna possível a elaboração de cenários futuros com a identificação dos impactos atuais e consequentes possibilidades viáveis de previsão.

A AAE deve ajudar a identificar a melhor opção para a estratégia de ação, identificando e analisando diferentes alternativas, minimizando danos e oferecendo opções para administrar essas possibilidades.

A elaboração do relatório da AAE é a quinta etapa. O relatório ambiental deve ser preparado para a identificação, descrição e avaliação do modo como os efeitos significativos se manifestarão através da implementação da proposta, com o registro das alternativas viáveis de acordo com os objetivos e o diagnóstico do meio em questão (FABBRO NETO, 2010). O relatório deve ser apresentado ao público num tempo hábil para que sejam possíveis modificações na descrição da área e das ações estratégicas.

A sexta etapa é a revisão do resultado dos procedimentos realizados, o que compreende a consulta pública. O envolvimento popular na tomada de decisão durante a realização da AAE traz vantagens na estrutura local, no conhecimento e pesquisa, propiciando maior sociabilidade e aceitação política das decisões, além de estimular a apropriação das decisões, contemplando as diferentes percepções ambientais.

A sétima etapa é a tomada de decisão estratégica, caracterizada por ser uma responsabilidade política.

A oitava etapa é o acompanhamento da implementação da decisão estratégica. Um modelo de monitoramento é proposto pelos responsáveis pela elaboração da $A A E$, o que permite que os atuais impactos da estratégia sejam testados contra as previsões, os problemas identificados e as bases de referência atualizadas para as futuras ações. Isso ajuda a garantir que as medidas mitigadoras propostas sejam aplicadas, e que impactos não previstos surpreendam as ações de planejamento.

Segundo Dalal-Clayton e Bass (2002) apud Fabbro Neto (2010), os governos não podem assumir a posição de monitoramento. É necessário que a responsabilidade do monitoramento seja compartilhada e, para isso, todo o processo deve ser documentado na forma de um relatório ambiental.

\section{APLICAÇÕES INTERNACIONAIS}

A aplicação da AAE é recente e está evoluindo rapidamente, como na Califórnia (EUA) e Holanda, que já incluíram o instrumento na sua legislação. Entretanto, houve aumento significativo na 
prática, pesquisa e na discussão a respeito da $A A E$, seus conceitos, objetivos e metodologias, apontados em diferentes estudos e aplicações, como a apropriação em planos diretores e em planejamentos territoriais (MANSUR, 2007).

Diversos países, como a Suécia, Canadá, Austrália e Nova Zelândia têm realizado um esforço considerável no sentido de adotar os procedimentos da AAE, e, segundo Costa et. al. (2009) a maior parte está sendo realizada voluntariamente e através de órgãos públicos.

As experiências internacionais com a prática da Avaliação Ambiental Estratégica têm fortalecido o consenso sobre as possibilidades desse instrumento como alternativa promissora de planejamento, capaz de auxiliar os tomadores de decisão na incorporação da questão ambiental na implementação das políticas, planos e programas governamentais. Conforme a OCDE (2012), os resultados produzidos em países como África do Sul confirmam os inúmeros aspectos favoráveis sobre as potencialidades da AAE.

As áreas de transporte e uso de solo estão entre os setores com as maiores experiências de AAE, segundo Dalal-Clayton e Sadler (2005) e Fischer (2007).

A avaliação de algumas experiências de aplicação da AAE para planos de uso e ocupação do solo permite que sejam identificadas as vantagens de aplicação deste instrumento para a gestão do território.

Para o planejamento de uso e ocupação do solo, a AAE proporciona um gerenciamento participativo das ações, envolvendo a população e as associações representativas de diferentes setores da comunidade que se relacionam com o crescimento das cidades no processo de tomada de decisão, durante as etapas de planejamento, execução e monitoramento, visando à preservação dos recursos do meio rural e urbano, integrando a qualidade ambiental com as demandas sociais.

Fischer (2007) descreve diferentes experiências de aplicação de AAE para gestão de uso de solo, como a avaliação de planos de desenvolvimento e planejamento urbano, entre eles:

\section{. Weiz, Áustria}

Para a revisão do planejamento de uso e ocupação de solo entre os anos de 1997 e 1998 de Weiz também foi aplicada a AAE. Oplanejamento urbano do município foi revisado e 27 áreas com demandas ou potencial para novos desenvolvimentos foram identificadas. Para maior eficiência das decisões, a revisão foi acompanhada do planejamento de uso do solo e da AAE com um horizonte de planejamento para cinco anos. 
Para cada área foram avaliados 3 cenários possíveis: uma não-ação, uma intenção do município e uma alternativa de fator ambiental mais forte. Os critérios ambientais e socioeconômicos foram usados para a avaliação dos diferentes usos propostos para o desenvolvimento de cada uma das áreas.

Segundo Fischer (2007), a decisão final não refletiu a opção de melhor qualidade ambiental pois as pressões políticas e interesses dos investidores não permitiram que os resultados da AAE fossem totalmente considerados. As razões para a escolha inicial das áreas não foram apresentadas, indicando que sua aplicação foi menos estratégica.

\section{. North Holland, Holanda}

O plano de desenvolvimento territorial da província de North Holland pretendia resolver questões como fraco desenvolvimento econômico, congestionamento, tráfego e pressão crescente sobre espaços naturais. Segundo Partidário (s.d.) a AAE considerou 4 cenários possíveis: crescimento econômico, proteção da identidade da região, desenvolvimento turístico e proteção da natureza e qualidade de vida.

Através de participação pública, os 4 cenários foram transformados em 2 alternativas:

. Consentimento de que a região precisava de mudança

- Tentativa de encontrar soluções que preservassem a identidade da região

Através da AAE optou-se por um plano baseado na segunda alternativa, com as melhores informações da primeira.

\section{. Rotterdan e Leiden, Holanda}

Em Rotterdam e Leiden, a AAE foi realizada para o desenvolvimento de novas áreas residenciais e de negócios, entre 1995 e 1997. O estudo foi realizado em função da escolha de áreas para o desenvolvimento destes municípios em conflito com a política nacional de desenvolvimento espacial e ambiental por impactar áreas protegidas da região metropolitana de Amsterdam. Procurou-se identificar possibilidades de alteração da legislação nacional para adaptar as propostas de desenvolvimento. Neste caso, optou-se por considerar, além dos aspectos ambientais, as variáveis econômicas e aspectos sociais (FISCHER, 2007).

Ainda, segundo o autor, a AAE incentivou o poder público a procurar áreas que não estivessem em conflitos com a legislação nacional e com a proteção ambiental. Ao avaliar as conseqüências das ações em longo prazo, também trouxe uma melhor hierarquização das políticas em diferentes níveis decisórios - nacional, regional e local e estimulou a comunicação de diferentes órgãos governamentais e da sociedade. 


\section{. Amsterdam, Holanda}

A AAE realizada para o plano de desenvolvimento de Amsterdam foi elaborada entre os anos de 1996 e 1998, enquanto não havia um procedimento formal regulamentado (FABBRO NETO, 2010). Foram avaliados os impactos do crescimento populacional para o desenvolvimento de áreas residenciais e de negócios, além de considerar os número de empregos. Segundo Fischer (2007), sem a aplicação da $\mathrm{AAE}$, as escolhas de desenvolvimento urbano costumavam ser determinadas por considerações mais econômicas.

Os principais cenários analisados envolveram a autorização de desenvolvimento somente de áreas já dotadas de infra-estrutura, um avanço ilimitado e, um meio termo entre as duas opções, com a possibilidade de expansão da infraestrutura aliada às existentes. As opções foram traduzidas em mapas utilizados para a previsão de impactos. Através deles e da participação pública, optou-se pela opção intermediária, onde o crescimento da malha urbana não se limita à existência de infraestrutura prévia, mas também não pode avançar para qualquer lado sem controle (FISCHER, 2007).

Correia (2009) destaca a aplicação da ferramenta no Planejamento Territorial de Nauen, Alemanha e no Plano Regional da Grande Estocolmo, Suécia.

\section{- Nauen, Alemanha.}

As experiências em AAE na Alemanha foram introduzidas formalmente antes da Diretiva Européia, em vários campos, incluindo o ordenamento e o planejamento territorial.

Na Alemanha existem quatro grandes níveis de tomada de decisão no planejamento territorial: federal, estadual, municipal e local. Todas as decisões sobre o território, independente do nível de decisão administrativa, devem considerar as políticas, planos e programas preparados para outros níveis.

A AAE realizada ao Planejamento Territorial do Município de Nauen pode ser considerada um exemplo de boa prática. Nauen está aproximadamente a $15 \mathrm{Km}$ a oeste de Berlim e possui 11.000 habitantes.

Devido à sua proximidade e acessibilidade através da linha de trem, a cidade pode acomodar um crescimento populacional significativo. O Plano Territorial de Nauen previa um crescimento populacional de $50 \%$.

Na AAE de Nauen não foram aplicadas as instruções da Diretiva Européia, sendo necessário melhorar a identificação e avaliação de todos os impactos incluindo aqueles relacionados com a saúde, aspectos culturais e materiais, população, biodiversidade; 
Os planos estratégicos não foram bem avaliados pela $A A E$ e as decisões estratégicas importantes foram tomadas sem considerar os seus impactos e sem uma participação pública suficiente.

\section{- Grande Estocolmo, Suécia}

Na Suécia não existe planejamento espacial ao nível nacional e regional e a responsabilidade é dos municípios.

A Grande Região de Estocolmo inclui a capital, Estocolmo, e possuí 1.8 milhões de habitantes e 26 municípios. Noventa e cinco por cento dos habitantes vivem nos dez por cento do território, o que constitui a área mais densamente construída/habitada, sendo que cinquenta por cento do emprego da região está em Estocolmo. A região cobre uma área de 649.000 ha, dos quais sessenta por cento é área agrícola ou florestal.

O Plano Regional tem um horizonte de 30 anos e stabelece os critérios para uso do território, áreas ricas em recursos hídricos, e orientações para a localização e construção de edifícios e instalações. Os objetivos são desenvolver a competitividade internacional, boas condições de vida para toda a população e um ambiente de sustentabilidade de longo prazo.

A AAE do Plano regional começou em 1997 e terminou em 2002.

Um dos objetivos da AAE foi facilitar a avaliação, para se perceber até que ponto as diferentes alternativas, medidas e propostas de planejamento contribuíram para alcançar as metas do planejamento regional, incluindo os objetivos ambientais regionais e nacionais.

A ferramenta atribuiu maior importância às questões ambientais; maior cooperação entre as diferentes administrações municipais e melhor nível de decisão política. Os resultados indicaram que identificar conflitos entre os aspectos econômico, ambiental e social é um assunto muito importante a ser considerado durante o processo de AAE.

A AAE permitiu a integração dos níveis ambiental, social e económico e envolveu escolhas de grande importância para a região de Estocolmo.

\section{Aberdeen, Escócia ${ }^{12}$}

Aberdeen é uma cidade na Escócia com cerca de 216.000 habitantes que realizou uma AAE para implementação de seu Plano de Desenvolvimento Local que, além do crescimento estratégico e local, pretende promover áreas de regeneração e melhorar a economia, a qualidade ambiental, a acessibilidade, as oportunidades de emprego e competitividade.

\footnotetext{
${ }^{12}$ Informações tiradas do Relatório de Avaliação Ambiental Estratégica para o Plano de Desenvolvimento Local de Aberdeen e do Relatório Ambiental para Estratégia Local de Habitação de Aberdeen disponível em http://www.aberdeenshire.gov.uk/green/assessment.asp.
} 
O programa de Estratégia Local de Habitação faz parte desse Plano e visa atender o aumento do número de famílias que está criando mais demanda por habitação e terra. Tem como meta fornecer instalações adequadas esporte, espaços abertos, habitação acessível e habitação familiar.

Entre os objetivos do programa traçado para o período de 2006-2011, estava

- aumentar a oferta de habitação acessível para 900 unidades por ano, de forma a produzir o crescimento económico sustentável da cidade;

- permitir que todos em Aberdeen tenham acesso a habitação que atenda às suas necessidades e aspirações;

- garantir o dsenho, condição, eficiência energética e gestão habitacional;

- criar comunidades seguras, sustentáveis que atendam as necessidades dos indivíduos, das comunidades e do meio ambiente.

A AAE teve como objetivos, entre outros:

- Manter a biodiversidade, evitando perdas irreversíveis

- Proteger a população de espécies nativas

- Melhorar a saúde e contribuir para a justiça social

- Manter e melhorar as oportunidades de acesso a espaços públicos e oportunidades de recreação

- Redução de ruído e vibração

- Gerenciar os riscos de inundação e limite de poluição da água

- Reduzir a contaminação, salvaguardar a qualidade e quantidade do solo

- Melhorar a qualidade dos resíduos e das águas superficiais e elevar o nível de resíduos reciclados

- Manter e melhorar a qualidade do ar

- Limitar as emissões atmosféricas para cumprir com as normas de qualidade do ar

- Reduzir a vulnerabilidade aos efeitos das mudanças climáticas, por exemplo inundações, interrupção de viajar por condições meteorológicas extremas e as emissões de gases de efeito estufa

- Promover um senso de lugar e qualidade da habitação

- Proteger e melhorar a qualidade e singularidade da paisagem de Aberdeen e da paisagem urbana

- Melhorar os níveis de construção e materiais de construção reutilizados

- Promover o uso sustentável dos recursos naturais e materiais 
- promover a requalificação de zonas industriais abandonadas.

Os problemas decorrentes do planejamento inadequado sem a realização da AAE poderiam ser:

- deterioração da qualidade do ar;

- deterioração da qualidade da água a partir de descarga de nutrientes das estações de tratamento de águas residuais;

- probabilidade de urbanizações inadequadas em planícies de inundação

- terrenos abandonados e vazios permanecendo subdesenvolvidos

- $\quad$ uso continuado e possível aumento de combustíveis fósseis;

- perda de biodiversidade

- pouco ou nenhum acesso a espaços abertos, emprego, educação e serviços, gerando assim a exclusão social

pouco ou nenhum desenvolvimento de instalações de recreação;

Entretanto, a AAE considerou a localização e a escala geral de desenvolvimento proposto no plano, identificando as principais considerações no desenvolvimento da estratégia como o uso eficiente dos edifícios existentes, terra e infra-estrutura; a acessibilidade de casas, serviços, espaços abertos e oportunidades de emprego através de uma variedade de opções de transporte; investimento em infraestrutura, incluindo o transporte e investimento educacional; a proteção da biodiversidade e do meio ambiente em geral, incluindo a consideração dos riscos de inundação.

Outros efeitos da aplicação do instrumento incluem a disponibilização de terrenos para grandes empreendimentos habitacionais e comerciais e incentivo a empreendimentos de uso misto. A AAE também assegurou que as áreas tivessem número suficiente de pessoas, casas e empregos para sustentar os serviços e instalações, além de estabelecer o adequamento das unidades habitacionais para acessibilidade à pessoas idosas e deficientes e não concentrar as habitações especiais em apenas uma área.

A AAE do Plano de Desenvolvimento Local considerou outros planos, programas e metas ambientais (nacionais, regionais e locais) relevantes para os principais problemas a serem analisados.

As mudanças na legislação, regulamentos, políticas e diretrizes continuam a influenciar o planejamento do uso da terra na Escócia, mas quaisquer alterações nas políticas serão monitorados durante todo o processo de $\mathrm{AAE}$, mantendo o processo interativo e atual. 


\section{APLICAÇÕES NO BRASIL}

Como já abordado nessa pesquisa, o crescimento das cidades vem acontecendo cada vez mais nas áreas periféricas, distantes das áreas urbanizadas com a existência de glebas vazias. A falta de regulamentação adequada na escala nacional, particularmente em relação ao meio ambiente, tem contribuído para o crescimento descontrolado, problemas com infraestrutura inadequada, carência de serviços e degradação ambiental. De um modo geral, a profunda diferença entre as regiões centrais e periféricas e entre os loteamentos criados para a classe alta e baixa é um sérios obstáculo para o desenvolvimento sustentável.

A experiência brasileira em AAE é recente e limitada e vem sendo implementada de modo periférico. Não há definição de marco legal, nem orientação e diretrizes técnicas que possam estabelecer uma base de referência para a sua prática voluntária.

As iniciativas registradas estão ligadas aos setores de infra-estrutura, notadamente aos segmentos de energia e transportes, e fortemente baseadas na AIA. Segundo Oliveira et. al. (2009), os órgãos ambientais tem atuado sobre a questão da implementação da AAE em diferentes estados a partir da adaptação de procedimentos da AIA de projetos e, geralmente, o instrumento é aplicado para a avaliação de grandes empreendimentos.

Apesar de a AAE ainda ser um instrumento em construção no país, algumas experiências práticas demonstram tentativas de inseri-la nas políticas setoriais.

Contudo, alguns estudos chamados de AAE são, na realidade, EIAs de grandes empreendimentos.

\section{. Rodoanel Mário Covas, SP.}

O projeto do Rodoanel foi concebido em quatro partes. A alça Oeste foi construída entre 1998 a 2002 e a hipótese de realizar uma AAE ocorreu quando o CONSEMA - Conselho Estadual do Meio Ambiente questionou a respeito do licenciamento ambiental das demais alças devido aos traçados das alças Sul e Norte cortarem áreas de proteção de mananciais e remanescentes de Mata Atlântica.

O setor de transportes do governo estadual, então, decidiu renomear o projeto para Programa Rodoanel e encaminhar a elaboração de um estudo de AAE para ser submetido à apreciação do conselho (TEIXEIRA, 2008).

Dessa forma, a A AAE teve como objetivo identificar os efeitos do Rodoanel sobre o ambiente natural e o ambiente construído. 
O resultado do processo de AAE foi uma série de recomendações incipientes. Os conflitos entre os interessados e os não interessados na realização do empreendimento permanecem. Os resultados da AAE não foram validados pelos grupos de interesse.

A intenção da realização da AAE foi encaminhar mais uma tentativa de validar a decisão de implantar o Rodoanel como melhor solução para os problemas de transportes e tráfego de veículos na RMSP, não sendo discutidas as implicações ambientais de outras possíveis opções para lidar esses problemas.

Segundo Sánchez (2008), a AAE do Rodoanel não trata de questões estratégicas de uso do solo e planejamento urbano e nem de diferentes alternativas de desenvolvimento para o futuro não influencia na decisão da construção da rodovia em si, apenas na identificação e escolha de rotas alternativas,

A construção do Rodoanel é um projeto, e a AAE deveria estar em um momento muito anterior a esse, no processo de tomada de decisão durante a discussão das políticas de transporte mais adequadas para a região (PELLIN et.al., 2011).

\section{. Gasoduto Bolívia Brasil.}

No caso da construção do Gasoduto BolíviaBrasil, foi realizada a primeira AAE do Brasil, em 1994, solicitada pelo BID - Banco Internacional de Desenvolvimento - como requisito para concessão do empréstimo e para oferecer às instituições financiadoras e executoras do projeto uma visão mais abrangente dos benefícios, impactos e riscos associados à obra. O estudo, realizado após o governo brasileiro já ter emitido sua licença ambiental prévia, foi, de acordo com Teixeira (2008), dissociado de qualquer processo de planejamento que eventualmente pudesse se apropriar dos seus resultados e recomendações.

Segundo Batmanian (2006) apud PELLIN et.al., 2011, representante do Banco Mundial, a realização da AAE para o Gasoduto visou incorporar na análise do empreendimento as consequências socioeconômicas e ambientais das transformações induzidas nos setores boliviano e brasileiro, destacando sua característica de AIA de grandes projetos.

\section{. Brasília Integrada, DF.}

Também podemos citar como exemplo de AAE realizada no Brasil o estudo do Programa de Transporte Urbano do Distrito Federal e Entorno - Brasília Integrada - elaborado pelo Governo do Distrito Federal (GDF) em 2004.

As ações propostas pelo programa possuem foco na implantação de uma operação do sistema de transporte público coletivo fundamentada na integração entre itinerários de ônibus e metrô. 
Na $A A E$, foram elaborados cenários tendenciais e exploratórios para a área de influência do Programa, considerando-se os horizontes temporais de 2006 a 2030.

A avaliação abordou o conjunto das ações do programa, estabelecendo as relações com os problemas de Brasília na área de transportes. Os objetivos da avaliação ambiental foram apresentar ferramentas que propiciassem ao GDF incorporar os aspectos socioambientais na formulação de uma política integral de transporte urbano; identificar os impactos estratégicos que pudessem derivar da implantação das intervenções físicas do programa; entender as relações entre os diferentes componentes e destes com a efetiva resolução dos problemas ambientais já instalados na área; identificar momentos críticos, benefícios e riscos socioambientais, de modo a poder preveni-los e ou mitigá-los; assegurar que as questões socioambientais sejam avaliadas no processo de decisão; prover mecanismos de controle social e divulgação das informações sobre o Programa. Cabe destacar que o programa deveria ser adequado às exigências do Banco Interamericano de Desenvolvimento (BID), e uma das exigências feitas pelo banco era a de que os deslocamentos realizados em automóveis particulares não podiam ser prejudicados mas, de preferência, melhorados.

A AAE analisou três alternativas:

- Alternativa "Nada a Fazer", que mantém o atual modelo operacional de linhas diretas sem integração, considerando somente melhorias físicas no sistema viário e nos equipamentos urbanos de apoio;

- "Alternativa 1", que integra o sistema em termos operacionais e tarifários, acrescenta às melhorias físicas a implantação de terminais de integração e admite a expansão da capacidade do Metrô/DF, com aquisição de maior número de trens unidade;

"Alternativa 2", que não amplia essa capacidade do Metrô/DF, mas busca aproveitá-la no seu todo, com a implementação da integração e das melhorias de infraestrutura que incluem os terminais de integração.

Após as avaliações de natureza econômica, financeira, operacional e, ainda, levando-se em conta os respectivos impactos ambientais, foi selecionada a alternativa 2 (dois).

A AAE para Brasília não discute outras perspectivas de planejamento associadas ao transporte, como habitação, controle de poluição, acessibilidade a equipamentos públicos e privados, promover o desenvolvimento social de regiões, estando muito próximo a um EIA. 
O planejamento enquanto prática governamental ainda não acontece no Brasil, seja pelas diversas formas de fragmentação do processo de gestão pública como também pela prática que ainda temos em focar a etapa de projeto como a mais importante no processo de desenvolvimento do país.

A potencialidade econômica do território permanece como condicionante do fluxo de investimentos que, segundo Oliveira et.al. (2009), não permite questionar a alocação das atividades econômicas com argumentos relacionados às questões ambientais.

Apesar disso, alguns aspectos reforçam a oportunidade, vantagens e a relevância do processo de AAE para o Brasil (EGLER, 2002):

- Grandes áreas a serem ocupadas, diferentemente de outros países

- Aplicação da AAE para reforçar o Programa de Zoneamento Ecológico Econômico - ZEE, cujo principal objetivo é o desenvolvimento do processo de avaliação do uso do território

- Fortalecer as oportunidades do processo de AAE na prática do planejamento para a questão ambiental e para viabilização do desenvolvimento sustentável.

\section{CONSIDERAÇÕES SOBRE AAE}

Com os princípios da AAE apresentados, fica clara a importância de introduzir esse instrumento nas etapas de planejamento governamentais.

O mesmo ocorre também nos programas habitacionais, onde precisamos aplicar os conceitos de sustentabilidade já no momento de sua concepção.

A experiência internacional demonstra que a aplicação da AAE auxilia o processo de elaboração dos planos de gerenciamento de uso do solo, promovendo melhoria da qualidade ambiental.

Por meio de metodologia adequada a AAE pode permitir o gerenciamento dos conflitos das ações propostas e definidas pelos programas habitacionais, segundo Oliveira (2008), ao ponderar e avaliar alternativas para tomadas de decisão.

A realização da AAE possibilita a inserção da variável ambiental durante o processo de tomada de decisão estratégica, permitindo a definição da melhor alternativa de desenvolvimento de acordo com os atores envolvidos (THÉRIVEL, 2004).

Entretanto, a questão ambiental brasileira continua subordinada a determinações econômicas sem, muitas vezes, oportunidade de articular seus próprios objetivos (OLIVEIRA et.al., 2009). 
O Programa Minha Casa Minha Vida, anunciado pelo governo federal em parceria com Estados e municípios, indica as dificuldades na busca de resultados a longo prazo relacionados ao meio ambiente.

A avaliação de impacto ambiental realizada durante as etapas de elaboração de políticas, planos e programas possibilita a inclusão da variável ambiental em tempo hábil para as adequações necessárias das propostas apresentadas. A discussão entre os diferentes atores promove melhor integração dos diferentes setores envolvidos no desenvolvimento urbano, contribuindo para amenizar conflitos.

A realização de uma $A A E$ durante a elaboração de programas habitacionais, como o Minha Casa Minha Vida, poderia garantir que as questões ambientais fossem discutidas, esclarecidas e acordadas entre os atores envolvidos, como na situação de Aberdeen.

As decisões seriam embasadas por uma base de dados ambientais constantemente atualizadas, que promoveriam a diminuição do tempo dos processos de tomadas de decisão oferecendo maior credibilidade às ações implantadas.

Dessa forma, a AAE como subsídio para o planejamento urbano sugere a importância de uma AAE que avalie os impactos causados pela mudança de uso do solo, como no caso de programas habitacionais. 
CAPÍTULO 3

AAE COMO INSTRUMENTO DE PLANEJAMENTO TERRITORIAL - PMCMV 
A AAE tem aparecido como uma forma de integrar AIA e planejamento participativo na promoção da sustentabilidade do uso e ocupação do solo municipal (SHEPERD \& ORTOLANO, 1996 apud FABBRO NETO, 2010). As experiências internacionais demonstraram o potencial da AAE para contribuir com o planejamento municipal de uso e ocupação do solo sustentável, mas, ao mesmo tempo, revelam algumas dificuldades em explorar completamente o potencial da AAE.

Alguns países como Inglaterra e Escócia, ao utilizar a AAE na elaboraçãoo de PPPs relacionados ao uso e ocupação do solo também a utilizam para planejamento de seus PPPs habitacionais.

No caso de programas habitacionais brasileiros, mais especificamente no PMCMV, uma questão fundamental relativa aos objetivos do programa e presente na maior parte dos PPPs habitacionais elaborados até então permanece: a casa própria seria a forma mais adequada de provimento de moradia para este contingente populacional?

Entre os objetivos do PMCMV estão "criar mecanismos de incentivo à produção e aquisição de novas unidades habitacionais ou requalificação de imóveis urbanos (..) para famílias com renda mensal de até R\$ 4.650,00" (BRASIL, LEI 12.424, de 16 de junho de 2011). Contudo, outras alternativas de provisão habitacional poderiam ter sido analisadas, como mutirões, arrendamento residencial e aluguel - este último menos oneroso e mais adequado para parcela da população, sujeita a processos diversos de mobilidade (BOLAFFI, S.D. apud NASCIMENTO e TOSTES, 2011).

Com a integração do processo de planejamento de PPPs à AAE é possível identificar questões como essa e encontrar alternativas mais adequadas ao meio e à sociedade.

A AAE de Planejamento Habitacional deve ser entendida como um procedimento contínuo e sistemático de avaliação da sustentabilidade ambiental, integrado no procedimento de elaboração dos PPPs, e deveria visar a garantia que os efeitos das soluções adotadas sejam considerados durante a sua elaboração e prática.

Esse objetivo, segundo Correia (2009) pode ser atingido através da ponderação de várias soluções e alternativas possíveis, contribuindo para a adoção de uma solução sustentável do ponto de vista ambiental, social, econômico e também do ponto de vista do desenvolvimento territorial da área estabelecida pela PPP.

A realização da AAE implica numa abordagem estratégica de planejamento, decorrente da previsão de eventuais efeitos significativos no ambiente que resultem da aplicação do Programa Habitacional. 
O Brasil ainda não tem uma estrutura ambiental onde todos os instrumentos regulamentados e integrados estejam atuando em prol dos seus verdadeiros objetivos, sem atender interesses de grupos específicos. Entretanto, as pressões recebidas internacionalmente e o passivo ambiental existente impõem medidas consistentes para que o interesse ambiental seja preservado através do instrumento adequado para este fim. (OLIVEIRA, 2008)

Como mostrado, algumas experiências chamadas de Avaliação Ambiental Estratégica já foram realizadas no Brasil, tanto no âmbito setorial como em ações de planejamento mais integradas e nos diferentes níveis da administração pública. Porém, foram avaliações conflitantes, muitas vezes realizadas em projetos, resultado de pressões externas de instituições multilaterais sem incorporar o processo devidamente.

Diante da pouca prática de AAE no Brasil, a construção da ferramenta deve passar por um processo evolutivo e sem sobressaltos como indicam Dalal-Clayton e Sadler (2005) apud Oliveira (2008). Para Fischer (2003), parece incerto como e em que medida os processos de elaboração de PPP devem realmente conduzir o processo de AAE.

Assim, entende-se que seja necessário identificar e compreender o alcance e a abrangência dos processos de planejamento setoriais, qual o poder de influência dos planejadores sobre essas decisões e a provável influência e benefícios que a AAE poderia trazer para esses processos. A maior vantagem da AAE deve ser sua capacidade de mudar o modo como as decisões são tomadas (PARTIDÁRIO, 1996)

Para melhor elaboração da proposta de estrutura da $A A E$, cabe apresentar um panorama geral do entendimento de alguns autores sobre o propósito e características gerais dessas estruturas previamente desenvolvidas.

Partidário (2012) defende a idéia de que a AAE ajuda a criar um contexto de desenvolvimento para a sustentabilidade, integrando as questões ambientais e de sustentabilidade na decisão.

Para a autora, a AAE, numa abordagem de pensamento estratégico, visa três objetivos:

- Encorajar a integração ambiental e de sustentabilidade, incluindo os aspetos biofísicos, sociais, institucionais e econômicos;

- Acrescentar valor ao processo de decisão, discutindo as oportunidades e os riscos das opções de desenvolvimento e transformando problemas em oportunidades;

- Criar uma cultura estratégica no processo de decisão, promovendo a cooperação e o diálogo institucionais e evitando conflitos.

Para a autora, o modelo de pensamento estratégico em AAE está estruturado em três fases de processo cíclico: Estabelecer o contexto da AAE e foco estratégico; Estabelecer os caminhos e diretrizes 
para a sustentabilidade; e uma fase contínua ligando a AAE ao processo de tomada de decisão durante a implementação além da monitorização, avaliação e comunicação.

A estrutura de AAE desenvolvida por Sadler (2000) apud Lemos (2011) identifica e descreve questões-chave como objetivos, conceitos, princípios e elementos de boas práticas da AAE, extraídos a partir de pesquisa sobre a experiência internacional. De acordo com o autor, estes aspectos têm aplicação genérica, inclusive em diferentes sistemas de AAE. Segundo Lemos (2011) a proposta de estrutura não está voltada para questões específicas relacionadas a procedimentos, metodologias ou arranjos institucionais.

Fischer (2006) apresenta uma estrutura para avaliar a prática existente e servir como base para a elaboração de orientações específicas para diversos contextos. É baseada nos sistemas de planejamento dos transportes dos países da Europa e nas propostas de vários autores. A estrutura apresenta questões a serem consideradas na avaliação dos diferentes níveis de planejamento: políticas, planos e programas. $\mathrm{O}$ autor defende que a estrutura deve ser avaliada e analisada criticamente antes de ser aplicada, permitindo a sua adaptação a diferentes contextos.

A forma que a AAE irá assumir depende da situação e do contexto em que ela é aplicada. Apesar disso, há uma série de etapas e procedimentos mínimos que constituem elementos de boas práticas da AAE. Assim, a AAE deve tratar algumas questões identificadas como centrais e essenciais para a discussão e implementação em contextos de planejamento, apresentadas na tabela 8.

A estrutura geral da AAE para o PMCMV deveria apresentar alguns aspectos conceituais e práticos para a implementação e aplicação de AAE para o planejamento do programa habitacional. Também deve ser baseada nos elementos gerais e centrais que envolvem o planejamento habitacional.

Como se baseia numa pesquisa teórica e bibliográfica sobre a evolução recente do tema, a estrutura geral apresenta vários elementos descritivos de ambos os processos; mas fornece alguns elementos prescritivos, já que é focada na prática e em como a AAE deve ser adotada e adaptada em diferentes contextos. 
TABELA 8: PASSOS MAIS UTILIZADOS NA APLICAÇÃO DA AAE PARA PPPS

\begin{tabular}{|c|c|}
\hline Estágios da AAE & O que decidir \\
\hline Identificar os objetivos da $A A E$, indicadores e metas. & $\begin{array}{c}\text { Quais os objetivos ambientais e de sustentabilidade, metas } \\
\text { e/ou indicadores para o PMCMV. }\end{array}$ \\
\hline $\begin{array}{l}\text { Descrever a base de referência ambiental, incluindo } \\
\text { tendências futuras; identificar questões e problemas } \\
\text { ambientais. }\end{array}$ & $\begin{array}{l}\text { Quais questões ambientais e de sustentabilidade a serem } \\
\text { consideradas durante as tomadas de decisão. }\end{array}$ \\
\hline $\begin{array}{c}\text { Identificar as ligações com outras ações estratégicas } \\
\text { relevantes. }\end{array}$ & $\begin{array}{c}\text { Quais as outras ações estratégicas influenciam a estratégia } \\
\text { em questão e como. }\end{array}$ \\
\hline $\begin{array}{c}\text { Identificar alternativas sustentáveis para implementar os } \\
\text { objetivos da ação estratégica. }\end{array}$ & Quais alternativas ou opções a serem considerados. \\
\hline Preparar o Relatório do Escopo; consulta. & O que incluir no Relatório. \\
\hline $\begin{array}{l}\text { Prever e avaliar o impacto das alternativas; comparar } \\
\text { alternativas; mitigar os impactos da(s) alternativa(s) } \\
\text { escolhida(s). }\end{array}$ & $\begin{array}{c}\text { Quais os efeitos das alternativas sobre os objetivos e } \\
\text { indicadores ambientais; quais as alternativas preferidas; } \\
\text { quais medidas mitigadoras a serem incluídas. }\end{array}$ \\
\hline Escrever o Relatório da AAE & Como apresentar os dados. \\
\hline Consulta & $\begin{array}{l}\text { Quem consultar; como responder aos resultados das } \\
\text { consultas. }\end{array}$ \\
\hline Monitorar os impactos ambientais da ação estratégica. & Como lidar com os impactos negativos da ação estratégica. \\
\hline
\end{tabular}

Fonte: Baseado em Sadler, 2000 e Therivel, 2004.

\section{PMCMV SEM AAE}

Como o PMCMV está em andamento desde 2009, procuramos exemplificar a importância da AAE para o Programa analisando a forma como este está sendo colocado em prática através de seus projetos. Os empreendimentos são efeito e consequência de um Programa formulado sem considerar aspectos importantes para os diferentes interessados e sem levar em consideração os aspectos ambientais e sustentáveis.

Desde a criação do SFH, em 1964, o loteamento ou conjunto habitacional localizado na periferia consagrou- se como o modelo principal, justificado pelo preço mais baixo dos terrenos.

O ministério das Cidades (2009) revela que, em 1985, menos de $10 \%$ dos terrenos adquiridos para a construção de conjuntos estava situado dentro da malha urbana ou imediatamente contíguos a ela e eram dotados de acesso a transporte e servidos de abastecimento de água e energia elétrica. 
De uma maneira geral, a produção de habitação de interesse social continua localizada nas franjas periféricas dos centros urbanos, devido ao alto custo da terra, ausência de estratégias fundiárias e, segundo o Ministério das Cidades (2009) de uma visão preconceituosa sobre a localização da população de baixa renda nas cidades. Dessa forma, os conjuntos habitacionais ficam, na maior parte das vezes, segregados da malha urbana, distantes das áreas concentradoras de empregos e das redes de equipamentos e de infraestrutura urbanas.

Logo, são necessários grandes deslocamentos, com altos custos de transportes coletivos e maior emissão de combustíveis fósseis.

"Trata-se de um modelo de urbanização baseado na expansão horizontal e na ampliação permanente das fronteiras, na subutilização da infraestrutura e da urbanidade já instaladas e na mobilidade centrada na lógica do automóvel particular. De um lado, a cidade expande, avançando sobre as áreas rurais e os perímetros urbanos, definidos em lei municipal, acomodando de forma arbitrária as áreas que já foram ocupadas e aquelas que serão ocupadas no futuro; de outro lado, os vazios urbanos e imóveis vagos permanecem ociosos por vários anos, provocando uma desintegração socioterritorial entre os bairros e as áreas centrais da cidade, dificultando as ligações entre bairros e elevando os custos de implantação da infraestrutura urbana." (MINISTÉRIO DAS CIDADES, 2009)

Como mostrado na Tabela 5 (pg. 33), existem mais de 7 milhões de domicílios vagos com potencial para serem habitados localizados em tecidos urbanos, áreas dotadas de infraestrutura básica e com ampla acessibilidade por transporte coletivo (FJP, 2011).

A ocupação de imóveis vagos no centro permitiria reduzir a pressão sobre o sistema metropolitano de transportes, otimizar a infra-estrutura e os equipamentos já instalados e evitar que a cidade continue a se expandir em áreas com precárias e de proteção ambiental.

No geral, pesquisas como as de Fix (2011) e Bastos (2012) apontam que o lançamento do PMCMV tem seguido mais o padrão global de acumulação de capital do que a resolução do problema da habitação no país.

Na maioria dos casos, os lucros das empresas privadas na produção da moradia só serão garantidos se o preço da terra a ser utilizada for compatível com os preços de comercialização e financiamento definidos pela Caixa Econômica Federal. Assim, o lucro obtido está associado tanto com o preço da terra como com a construção. Maricato (2009) afirma que aqui está o grande "nó" do programa: não existe nele qualquer articulação entre política habitacional e política fundiária. Embora existam instrumentos urbanísticos do Estatuto da Cidade e dos Planos Diretores Participativos que garantam essa articulação, não há nenhuma vinculação institucional entre eles e o programa de financiamento. 
Neste aspecto, o programa se parece em muito com o BNH: não existe um vínculo entre política habitacional e política fundiária.

Dessa forma, não há um direcionamento do PMCMV para tratar a questão do déficit habitacional brasileiro de forma correta. O maior aporte está concentrado para a produção de habitação-mercadoria (BASTOS, 2012).

Idealmente, agentes responsáveis pelas PPPs deveriam indicar os seus objetivos e questões estratégicas, assim como as suas prioridades apoiadas por uma visão do futuro. Mas, algumas vezes, o processo não é tão simples assim (PARTIDÁRIO, 2012). O problema de decisão, na perspectiva do responsável pela estratégia, pode simplesmente limitar-se à preparação e aprovação de um plano ou programa.

Para o presente trabalho a Figura 10 representa uma hipótese de ação estratégica na elaboração do PMCMV, elaborada de acordo com as informações coletadas.

A opção adotada no caso do PMCMV parece ter sido mais pautada pela urgência em garantir o acesso aos recursos econômicos, do que pela necessidade de atingir os objetivos habitacionais.

Nesse caso, os municípios pouco influenciam na localização da produção, já que a estrutura de provisão passou a seguir a estrutura de mercado. Em termos ideais, Cardoso e Aragão (2013) afirmam que o controle dos municípios sobre o PMCMV deveria ocorrer através de mecanismos regulatórios, já que cabe a eles a responsabilidade pela aprovação dos projetos.

Entretanto, não podemos afirmar que apenas o zoneamento imposto pelos Planos Diretores para a construção dos projetos do Programa seja capaz de suprir as necessidades encontradas. Pela legislação urbana, é possível construir imensos loteamentos em que cada terreno legalmente edificável, mas o resultado do ambiente construído não é considerado.

Dessa forma, conjuntos de grande porte acabam, muitas vezes, sendo construídos sem os equipamentos necessários, apenas com reserva de área para sua implementação, e sua população tem de buscar o atendimento em outros bairros, às vezes distantes.

Na perspectiva econômica, Bastos (2012) demonstra que restringir a utilização dessas terras periféricas poderia enfraquecer os efeitos esperados do programa sobre a aceleração do mercado de construção civil e causar prejuízos às incorporadoras. Na prática, as empresas privadas (investidores, construtoras e incorporadoras) que definem onde irão construir e obter maiores lucros (CARDOSO e ARAGÃO, 2013).

A Avaliação Ambiental solicitada às empresas construtoras para aprovação dos projetos é a Licença Ambiental Simplificada - LS, licença única que compreende a localização, instalação e operação 
dos empreendimentos, avaliando apenas os aspectos relacionados ao empreendimento em questão. Entretanto, o PMCMV traz problemas para além dos limites dos projetos, relacionados ao âmbito da cidade.

A localização para o PMCMV é tão importante que o Ministério das Cidades produziu uma cartilha "Como produzir moradia bem localizada com os recursos do programa Minha casa minha vida?" direcionando os agentes envolvidos a aplicarem o Estatuto da Cidade para garantir que o PMCMV seja aplicado em áreas consolidadas.

FIGURA 10: PROCESSO DE DECISÃO ESTRATÉGICA DO PMCMV SEM A VARIÁVEL AMBIENTAL.

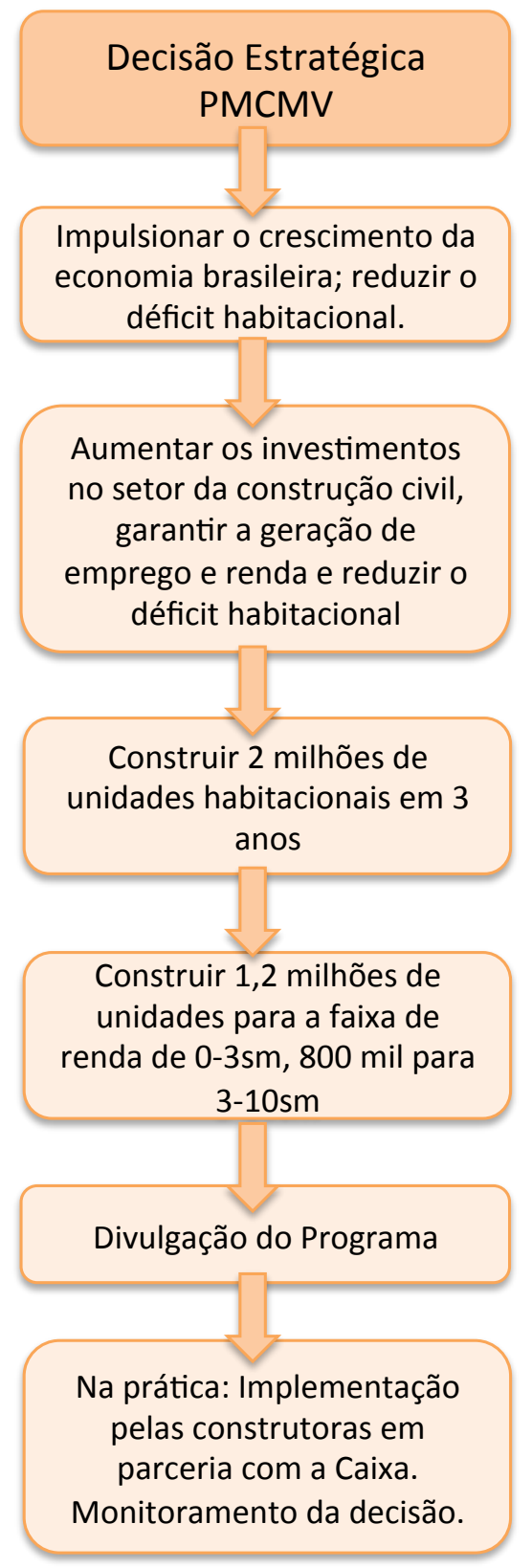

Fonte: Baseado em Thérivel, 2004; Oliveira, 2008; Caixa, 2010. 
Tanto a Política Nacional de Habitação como o Plano Nacional de Habitação tem como um de seus objetivos garantir a construção de moradias de interesse social em áreas bem localizadas e não foram consideradas. Várias estratégias propostas pelo PlanHab poderiam ser positivas, como o "subsídio localização" valor adicional a ser concedido aos empreendimentos habitacionais localizados nas áreas mais centrais e consolidadas (BONDUKI, 2009).

Apesar disso, o governo federal não é capaz de garantir a localização adequada do PMCMV sozinho. Os municípios precisam estar envolvidos. Cabe a eles, por meio dos planos diretores e habitacionais, definir os locais onde deve ser estimulada a implantação de novos empreendimentos. Além disso, o PMCMV não fornece nenhum papel específico aos Estados ou Regiões Metropolitanas.

A base institucional e organizacional do PMCMV é a experiência da Caixa Econômica Federal no gerenciamento do Programa de Arrendamento Residencial. Nele, a Caixa distribui os recursos para as empresas a partir de projetos aprovados pelas Prefeituras e enquadrados dentro das faixas sociais a serem atendidas. Dessa forma, o setor público, principalmente na escala municipal, deixa de ser o agente promotor (CARDOSO e ARAGÃO, 2013)

O leque de alternativas previstas no PlanHab ou na PNH poderia ser alcançado através da articulação dos atores e PPPs envolvidos. Isso demonstra a falta de integração do Programa com outros PPPs e ações estratégicas e ambientais. A Figura 11 apresenta o processo que culmina na estratégia do planejamento habitacional do PMCMV sem considerar outras PPPs.

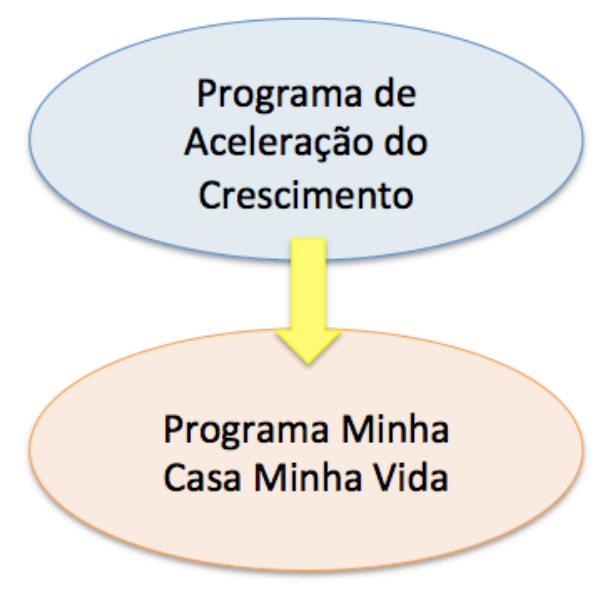

Fonte: Modificado de Oliveira (2008). 
A produção de moradias populares para além dos limites da cidade acabam prejudicando a todos, afirmam Rolnik e Nakano (2009). Além de encarecer a extensão das infraestruturas urbanas, o afastamento entre a moradia e os locais de trabalho e equipamentos urbanos encarecem os custos da mobilidade urbana e aumentam a segregação sócio-espacial. As viagens diárias congestionam as vias e os transportes coletivos, prejudicando a qualidade de vida coletiva. O aumento do uso de automóveis, que usam combustíveis fósseis e emitem gás carbônico, contribui para a poluição do ar, o aquecimento global e as mudanças climáticas.

Para situar o problema da periferização, Cardoso e Aragão (2013) fizeram uma análise da distribuição dos empreendimentos entre município núcleo e municípios periféricos das metrópoles que mostra a forte tendência à concentração dos empreendimentos na faixa de 0-3 SM nas periferias (TABELA 9).

Até maio de 2010 não haviam sido aprovados projetos para a faixa de 0-3 SM no município de Itaboraí, na RMRJ, situado em área de forte dinâmica demográfica e urbana, onde a demanda por moradia e o consequente crescimento de assentamentos precários vem se revelando um processo extremamente preocupante. Grande parte do território poderá ficar desassistida, apesar das pretensões universalistas do programa.

O trabalho de Campos e Mendonça (2013) demonstra que o mesmo acontece na Região Metropolitana de Belo Horizonte. Há uma intensa produção de habitação de interesse social nas periferias, inclusive incorporando novas áreas à mancha urbana metropolitana.

Na Região Metropolitana de Fortaleza o caso não é diferente. Quase todos os empreendimentos do Programa para famílias de 0 a 3 SM se encontram nas franjas de municípios periféricos, como mostram Pequeno e Freitas (2013).

Já na Região Metropolitana de Belém, nenhum empreendimento destinado à faixa de 0-3sm foi contratado até 2011 (CARDOSO et. al. 2013). O déficit habitacional na região é de 15\% dos domicílios urbanos, sendo que $87,9 \%$ correspondem à faixa salarial mais baixa. Os empreendimentos contratados para as faixas de 3 a 10 sm, estão localizados na periferia, com exceção de um único residencial.

Exemplos de projetos tidos como bem sucedidos, como o Conjunto Jacinta Andrade, em Teresina, $\mathrm{PI}$, projetado com 4300 unidades também apresentam problemas devido à localização periférica. Com cerca de 10 mil habitantes, os moradores reclamam da falta de transporte público eficiente, escola, mercado público e água de qualidade. 
TABELA 9: DISTRIBUIÇÃO DOS EMPRENDIMENTOS DO PMCMV

\begin{tabular}{|c|c|c|}
\hline \multicolumn{3}{|c|}{$\begin{array}{l}\text { Distribuição Regional dos Empreendimentos PMCMV, Fases } 1 \text { e } 2 \text { para a } \\
\qquad \text { Faixa de Renda 0-3 SM }\end{array}$} \\
\hline Regiões Metropolitanas & $\begin{array}{l}\text { Total de Unidades } \\
\text { Construídas no } \\
\text { Município Pólo da RM }\end{array}$ & $\begin{array}{l}\text { Total de Unidades } \\
\text { Construídas no } \\
\text { Restante da RM }\end{array}$ \\
\hline RM Belém & 0 & 4.124 \\
\hline RM Manaus & 5.384 & 1.516 \\
\hline RM Macapá & 2.148 & 0 \\
\hline RM Salvador & 6.907 & 11.472 \\
\hline RM Fortaleza & 352 & 2.738 \\
\hline RM Natal & 896 & 5.429 \\
\hline RM São Luiz & 3.496 & 15.094 \\
\hline RM João Pessoa & 828 & 597 \\
\hline RM Recife & 0 & 1.697 \\
\hline RM Teresina & 9.173 & 3.147 \\
\hline RM Maceió & 499 & 1.093 \\
\hline RM Aracajú & 281 & 251 \\
\hline RM Goiania & 4.526 & 2.708 \\
\hline RIDE Brasília & 30 & 1.036 \\
\hline RM Cuiabá & 2.743 & 3.291 \\
\hline RM Belo Horizonte & 1.325 & 4.730 \\
\hline RM São Paulo & 1.472 & 6.924 \\
\hline RM Campinas & 4.808 & 5.637 \\
\hline RM Santos & 0 & 1.980 \\
\hline RM Vitória & 0 & 120 \\
\hline RM Rio de Janeiro & 18.949 & 18.173 \\
\hline RM Curitiba & 3.884 & 1.783 \\
\hline RM Londrina & 3.546 & 1.281 \\
\hline RM Maringá & 108 & 463 \\
\hline RM Porto Alegre & 1.152 & 3.803 \\
\hline RM Florianópolis & 0 & 1.645 \\
\hline RM Carbonífera & 272 & 236 \\
\hline RM Foz do Itajaí & 48 & 0 \\
\hline RM Norte/Nordeste Catarinense & 2.024 & 936 \\
\hline RM Vale do Tubarão & 224 & 86 \\
\hline RM Vale do Itajaí & 1.824 & 336 \\
\hline
\end{tabular}

Dados obtidos entre março de 2009 e maio de 2012. Fonte: Adaptado de Cardoso (2013). 
Em São Paulo a implementação do programa não ocorre de maneira diferente. Através dos dados fornecidos pelo Departamento de Produção Habitacional do Ministério das Cidades, foi possível elaborar um mapa com a localização dos empreendimentos do PMCMV destinados à faixa de 0-3 SM entregues e em construção no município até fevereiro de 2012. (FIGURA 12).

FIGURA 12: PMCMV NO MUNICÍPIO DE SÃO PAULO - FAIXA DE 0-3 SM.

\section{PMCMV NO MUNICÍPIO DE SÃO PAULO - 0-3 SM}

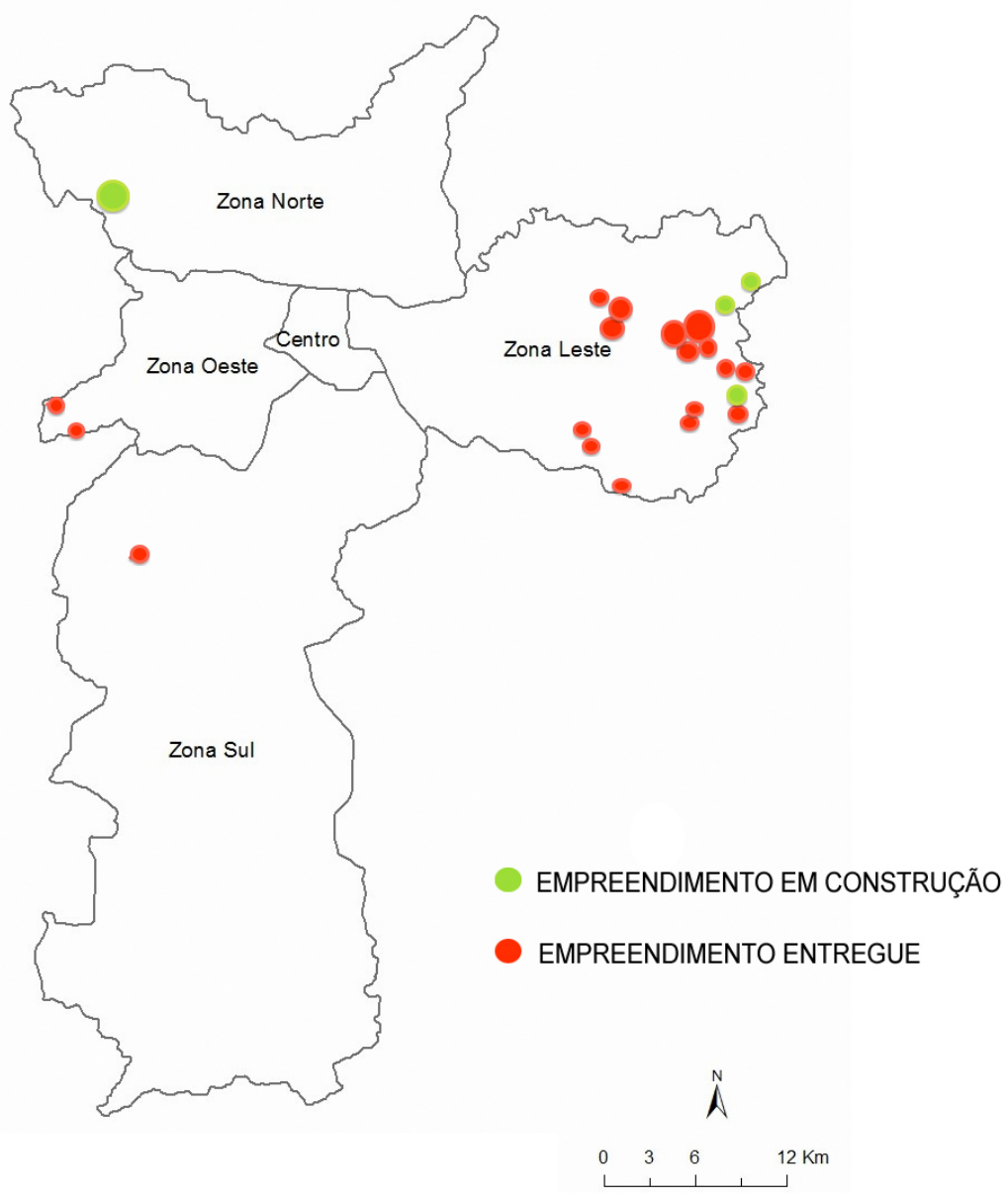

Elaborado pela autora com dados fornecidos pelo Departamento de Produção Habitacional do Ministério das Cidades, 2012.

Como podemos observar, mais uma vez o Programa localiza-se afastado do centro, aumentando a segregação social e a demanda pelo acesso à infraestrutura urbana, como transporte coletivo, educação, saúde, causando uma consequente degradação do meio ambiente. 
A desigualdade das condições urbanas expressa-se ainda como desigualdade ambiental, se consideramos que o PMCMV, sem uma avaliação adequada, pode vir localizar-se em áreas de maior exposição a situações insalubres (contaminação da água, do solo e do ar) e inseguras (riscos de acidentes de diversos tipos).

É possível encontrar conjuntos construídos em área de risco, como o conjunto do bairro Palmeiras, em Governador Valadares, MG. Segundo o Jornal Estado de Minas ${ }^{13}$, 14 das 96 unidades habitacionais já estão condenadas devido aos problemas de erosão do solo.

Alguns projetos do PMCMV foram construídos sobre área de preservação permanente (APP), como o caso do Condomínio Bosque Verde, em llhéus. O conjunto foi construído sobre uma área de manguezal e abriga 272 famílias.

Além disso, existem diversos outros projetos com problemas estruturais, como os condomínios Ipê Branco e Amarelo, no Realengo, RJ, entregues em 2010, que já apresentam rachaduras e fissuras em todos os blocos, dentro e fora dos apartamentos.

Nos condomínios Santa Helena e Santa Lúcia, em Duque de Caxias, RJ, as 389 casas foram inundadas por também estarem em área de risco. Segundo Cardoso (2013), não existe uma estrutura clara de fiscalização das obras, já que a Caixa ocupa-se mais de acompanhar os cronogramas físicofinanceiros das construções enquanto as prefeituras não estariam preparadas para identificar os problemas, ficando o controle de qualidade a cargo da própria construtora.

À medida que a cidade cresce de maneira periférica e desordenada, podemos verificar diversos impactos como inundações devido ao aumento de área impermeabilizada, aumento dos custos com sistemas de drenagem urbana e transporte (TUCCI, 2002 apud Oliveira, 2008).

Novamente cabe ressaltar que tanto a PNH como o PlanHab prevêem que a localização dos projetos habitacionais ocorram em áreas centrais e providas de infraestrutura.

Além dos problemas relacionados à periferização, o PMCMV elaborado sem uma AAE desconsidera as diferenças entre os aspectos culturais e climáticos do país.

O Zoneamento Bio Climático Brasileiro faz parte da NBR 15220-3 (ABNT 2005) e divide o território brasileiro em oito zonas relativamente homogêneas quanto ao clima (FIGURA 13). Para cada zona são feitas recomendações técnico-construtivas para a otimização do desempenho térmico das habitações de interesse social, através de sua melhor adequação climática (ABNT, 2005)

Estas zonas tem relação com as características climáticas das diversas áreas do território, que não obedecem ao mapeamento político ou divisão em estados ou regiões econômicas. O Zoneamento

\footnotetext{
${ }^{13}$ Publicado em 14/04/2011 em www.em.com.br
} 
permite considerar a zona climática de cada cidade e, com isso, indicar estratégias e diretrizes construtivas bioclimáticas recomendadas para cada local.

Os parâmetros e diretrizes para cada uma das zonas são:

- tamanho das aberturas para ventilação (expressas como percentual de área de piso);

proteção das aberturas;

- vedações externas, parede externa e cobertura, informando o tipo de vedação (leve oupesada, refletora ou isolada).

- estratégias de condicionamento térmico passivo.

\section{ZONEAMENTO BIOCLIMÁTICO BRASILEIRO}

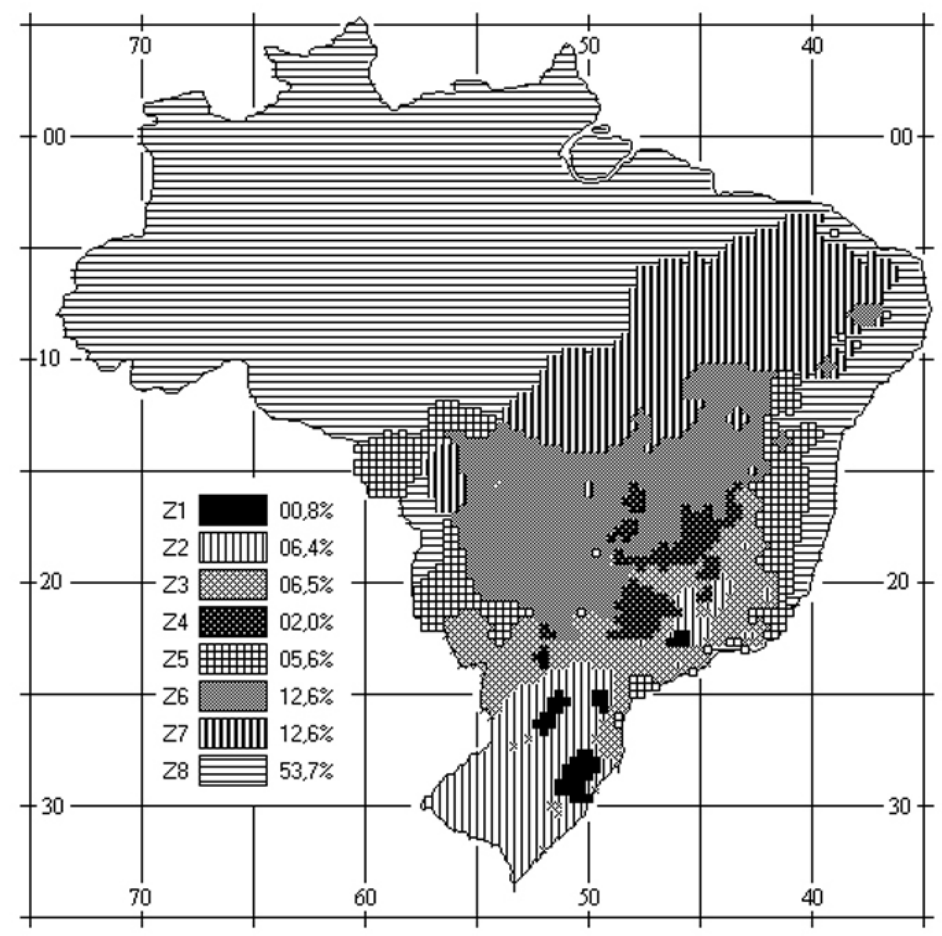

Fonte: NBR 15220-3, ABNT, 2005. 
O dimensionamento das necessidades habitacionais deve ser apoiado também por estudo das características demográficas da população que se almeja atender. Através desses estudos poderia ser possível adequar a tipologia e os métodos construtivos de acordo com as características climáticas de cada região.

A Fase 2 do PMCMV considera a NBR 15220-3 para a possível utilização de aquecimento solar nas unidades habitacionais, mas não para a tipologia e métodos construtivos.

Assim, a mesma tipologia habitacional é utilizada para Manaus e Porto Alegre, áreas com características climáticas e aspectos sócio culturais extremamente diferentes.

Como apresentado anteriormente, o PMCMV foi baseado no modelo de provisão habitacional mexicana e chilena: subsídios públicos individuais permitem às famílias de menor renda comprar no mercado produtos ofertados por construtoras privadas. 0 modelo se completa com disponibilidade de crédito: quanto menor é a renda, maior é o subsídio e menor é a parcela de crédito que entra para viabilizar a compra.

Segundo Rolnik (2012), este modelo praticamente pôs fim à produção informal de habitação no Chile e criou, ao longo de 3 décadas, mais de um milhão de soluções habitacionais, transformando-se em grande referência de política habitacional. Hoje, no entanto, o Chile vive o dilema do que fazer com os seus "com teto".

As milhares de casas e apartamentos da suposta bem sucedida política habitacional chilena produziram um território marcado por uma segregação profunda, onde a população de baixa renda vive na periferia de péssima qualidade urbanística e, muitas vezes, também, de péssima qualidade de construção, marcada por sérios problemas sociais, como tráfico de drogas e violência doméstica (ROLNIK, 2012).

Deixada para o mercado a decisão de onde e como deveria ser produzida, a cidade resultante desse modelo de provisão habitacional tomado como um dos exemplos pelo PMCMV é simplesmente desastrosa.

A elaboração, implementação e a distribuição de recursos do PMCMV deixa de passar por mecanismos de participação e controle social. A justificativa adotada originalmente, segundo Cardoso e Aragão (2013), foi a de agilização dos processos de alocação e utilização de recursos para viabilizar os objetivos econômicos do programa.

Por outro lado, a descentralização e a gestão do programa através da Caixa pode ser vista como uma alternativa que agiliza o acesso aos recursos pelo setor privado, que não precisa operar através de 
contratações e licitações públicas, como seria o caso se a iniciativa dos programas fosse das administrações públicas.

Nesse sentido, pode-se perceber as contradições de um programa com objetivos ao mesmo tempo econômicos e sociais, que pretende solucionar o déficit habitacional unicamente através da atuação da iniciativa privada. (CARDOSO e ARAGAO, 2013)

Os problemas habitacionais presentes, de acordo com Bonduki (2009), tendem a se agravar com a perspectiva dos novos empreendimentos previstos e tornam imprescindíveis a existência de instrumentos para a gestão da área de habitação.

Caso não sejam realizadas mudanças substanciais na forma de gerenciar o espaço das cidades, sem uma visão coordenada e integrada entre as diferentes esferas de poder e de planejamento, Tucci (2002) apud Oliveira (2008) acredita que o prejuízo para a população e para o ambiente pode se tornar irreversível.

\section{PMCMV COM AAE}

Considerando a forma como o PMCMV vem sendo implementado nesses 4 anos, podemos simular quais modificações poderiam ocorrer caso a AAE fosse aplicada na elaboração e manutenção do Programa.

Cabe ressaltar que esse trabalho não tem a intenção de realizar uma AAE no Programa em questão, mas analisar a capacidade do instrumento em contribuir ambiental, econômica e socialmente para o PMCMV.

Segundo o Ministério do Meio Ambiente (2002), a primeira questão a ser respondida é se existe a necessidade de se aplicar a AAE à PPP em análise. Algumas questões devem ser observadas para definir a necessidade a AAE.

Primeiramente cabe definir o grau estratégico da PPP. Segundo Partidário (2012), PPPs com natureza estratégica são determinados pela visão de um futuro desejável; têm objetivos estratégicos de longo prazo consistentes com essa visão; definem estratégias para atingir os objetivos pretendidos; são flexíveis tanto na formulação como na implementação; e apresentam uma direção para o desenvolvimento.

Para estabelecer o grau de estratégia do PMCMV devemos responder às seguintes perguntas feitas pelo MMA (2002):

- Faz parte da visão estratégica ou do Plano de Governo? 
- Atende algum setor estratégico da economia?

- Tem repercussões nas Contas Nacionais ou em compromissos assumidos pelo país?

- Faz parte do Plano PluriAnual de Investimento?

- A participação do setor publico é importante?

Dessa forma, o PMCMV pode ser considerado ação estratégica pois:

- Faz parte do Plano de Governo Federal, tratando-se de uma questão política, não somente técnica pois envolve conflitos de interesses;

- Busca impulsionar a economia do país através do desenvolvimento do setor da construção civil;

- É responsável pelo aumento de cerca de 0,08\% do PIB por ano de implementação (SHIMIZU, 2010);

- Faz parte do Plano PruriAnual Mais Brasil 2012-2015;

- Tem a participação do setor público;

- Relaciona-se com outras PPPs e legislações.

Para estabelecer a necessidade da AAE o MMA (2002), além do nível estratégico da PPP, afirma que devemos considerar a probabilidade de haver conseqüências ambientais significativas decorrentes de sua implementação. Essa questão pode estar apoiada em listagens de PPP que requerem uma AAE, estabelecida em regulamentos ou desenvolvidas em outros países.

Também podemos analisar a necessidade da AAE verificando se a implementação da PPP:

- Afeta recursos naturais importantes;

- Implica desmatamento expressivo, direta ou indiretamente;

- Implica uso intensivo de recursos hídricos;

- Provoca modificações substanciais no uso e ocupação do solo da região de interesse ou em algum ecossistema frágil;

- Necessita que outras PPP sejam implantadas para otimizar seus benefícios;

Definido o grau estratégico do PMCMV, podemos concluir que existe a probabilidade de haver consequências ambientais significativas através das consequências do processo de periferização decorrente da implantação dos projetos advindos do Programa. Se considerarmos as aplicações 
internacionais de $A A E$, observamos que alguns países utilizam-na como ferramenta para auxílio do ordenamento territorial ou PPPs habitacionais, como Holanda ${ }^{14}$ e Escócia.

Além destes aspectos, o MMA (2002) afirma que devem ser considerados os de natureza socioeconômica, de modo que se identifiquem os conflitos potenciais entre os objetivos da PPP e as dificuldades de concretizá-los simultaneamente.

Para isto, propõe que as seguintes questões sejam respondidas. A implementação da PPP:

- Gera empregos e oportunidades de trabalho?

- Contribui para melhorar a receita orçamentária dos municípios de interesse?

- Provoca efeitos multiplicadores favoráveis em termos de renda e emprego?

- Melhora as condições de vida de parte expressiva da população?

Com o que vimos até aqui, podemos afirmar que o PMCMV apresenta impactos ambientais, sociais, econômicos potenciais de larga escala, cumulativos, sinérgicos, sejam positivos e/ou negativos como possíveis modificações no uso e ocupação do solo de diferentes municípios, possível alteração da qualidade do ar, solo e água de maneira indireta através da emissão de gás carbônico decorrente dos maiores deslocamentos, possibilidade de causar erosão e aumento da necessidade do número de redes de tratamento de esgotos. Também necessita da implantação de outras PPPs, como a PNH, PlanHab e Planos Diretores Municipais para otimizar seus benefícios.

Também já está claro que o Programa gera empregos e renda para os diferentes agentes participantes, além de melhorar, no que diz respeito à quantidade de unidades habitacionais, as condições de vida da população atendida.

Dado o caráter especulativo da apropriação privada e os impactos urbanos e ambientais da sua localização apresentados aqui, pode-se concluir que o equacionamento das necessidades habitacionais pelo PMCMV pode ser aperfeiçoado com a aplicação da AAE. Os princípios gerais relacionados ao PMCMV são apresentados no Quadro 4. Esses princípios sintetizam as diretrizes gerais a serem observadas num sistema de planejamento onde existe a possibilidade de aplicar a AAE para o referido programa.

Entretanto, uma análise mais aprofundada sobre a aplicação desse instrumento na PPP em questão pode fornecer informações sobre as vantagens para o PMCMV.

\footnotetext{
${ }^{14} \mathrm{Na}$ Holanda, habitação, planejamento territorial e meio ambiente integram um mesmo Ministério e são tratadas pela AAE de planejamento territorial (MMA, 2002).
} 
A AAE é um instrumento de política ambiental que possibilita a integração de diversos objetivos presentes no planejamento territorial. Deste modo, seriam acrescentados outros objetivos identificados nas PPPs já elaboradas que se relacionariam aos objetivos da PMCMV, no caso, impulsionar a economia do país reduzindo o déficit habitacional.

\section{QUADRO 4: PRINCÍPIOS GERAIS E SETORIAIS: AAE E PMCMV}

\begin{tabular}{|c|}
\hline Questões setorias - Programa Minha Casa Minha Vida \\
\hline Bases para aplicação da AAE \\
\hline $\begin{array}{l}\text { A AAE de programas habitacionais deve considerar a inserção da variável ambiental e sustentável (ambiental, } \\
\text { social e econômica) no PMCMV, além dainterface com diferentes PPPs e legislações relevantes. } \\
\text { O estabelecimento de requisitos legais e formais que requerem ou estimulem a aplicação da } \\
\text { AAE é o principal meio para garantir a incorporação do instrumento e da variável ambiental no } \\
\text { planejamento de programas habitacionais. }\end{array}$ \\
\hline Cenário Institucional \\
\hline $\begin{array}{l}\text { Identificar todo o quadro institucional e agentes participantes relacionados ao planejamento do PMCMV. } \\
\text { Incentivar a adoção da AAE em ações de planejamento conjuntas, com compartilhamento de responsabilidades } \\
\text { não só na elaboração das estratégias, mas também na sua execução e implantação. }\end{array}$ \\
\hline Questões e Escopo \\
\hline $\begin{array}{l}\text { Identificar questões que foram deixadas de fora do escopo e precisam ser reavaliadas; } \\
\text { Buscar a integração das ações do PMCMV com outros PPPs integrados. A AAE deve oferecer oportunidades } \\
\text { reais de discutir opções, alternativas e diferentes ações, bem como influenciar todo o sistema de planejamento } \\
\text { habitacional, oferecendo oportunidades para uma avaliação integrada e abrangente. Deve ser capaz de } \\
\text { influenciar os objetivos e características gerais do PMCMV, as características locacionais de forma ambiental, } \\
\text { social e economicamente sustentável e a gestão da oferta e da demanda. }\end{array}$ \\
\hline
\end{tabular}

Fonte: Modificado de Lemos (2011).

A AAE permite que os conflitos existentes devido aos diversos interesses quanto à estratégia em questão sejam melhor analisados e os critérios sociais, ambientais e econômicos identificados para a realização do macrozoneamento que será realizado a partir da base ou estudo de referência ambiental (PIZELLA, 2010).

Partidário (2012) orienta que, na prática, a AAE não deve resumir-se à avaliação direta dos efeitos ambientais das propostas, mas sim concentrar-se na avaliação das condições para o desenvolvimento (por exemplo questões institucionais, políticas, econômicas, sociais). Dessa forma, a 
capacidade de decisão para evitar futuros efeitos ambientais negativos resultantes de decisões de desenvolvimento a níveis de projeto pode ser melhorada.

Segundo o OCDE (2012), os programas setoriais não podem ser vistos isoladamente, uma vez que existem claras ligações entre eles. O setor da habitação, por exemplo, está ligado a todos os outros setores, tais como uso e ocupação do solo, transporte e energia. A AAE deve ter como um de seus objetivos a oportunidade de coordenação e integração com outros setores, bem como a identificação dos impactos cumulativos resultantes destes programas setoriais.

A escala e natureza do PMCMV requerem mais do que um EIA ou uma LS. A AAE analisa os riscos ambientais associados e fornece uma estrutura para que a gestão e monitorização ambiental sejam acordadas e convertidas em elementos específicos do programa. A AAE pode influenciar também o formato geral do programa ao apontar para as ligações entre o setor habitacional e outros setores, e para os potenciais efeitos cumulativos do PMCMV.

Para estabelecer o problema de decisão e o objeto da avaliação, a AAE deve iniciar um diálogo com os líderes de planejamento e estar fortemente ligada ao processo de formulação da PPP, comunicar bem, desempenhar o papel de facilitador, proporcionar ajuda na busca do problema de decisão e do objeto da avaliação e compreender as preocupações e as perceções do responsável pela estratégia.

A AAE aplicada ao programa deve permitir que o princípio da sustentabilidade percorra todos os níveis de decisão e potencialize os efeitos deste conceito a favor da sociedade. Particularmente nos países em desenvolvimento, onde o ambiente adquire um significado além dos aspetos biofísicos, relacionando-se mais estreitamente com a qualidade de vida e o crescimento, a enfase da $A A E$, de acordo com a OCDE (2012) em questão deveria colocar-se numa avaliação integrada dos fatores ambientais, sociais e econômicos, e de fatores ainda mais abrangentes, como as dimensões institucional e de governança.

A avaliação dos PMCMV em conjunto com outros programas setoriais é relevante para possibilitar uma visão geral e integrada do desenvolvimento, bem como a identificação de prioridades e o impacto das diferentes opções no território. Porém, entende-se que, se a AAE for aplicada sem um cuidadoso respaldo conceitual e sem apropriação por parte dos tomadores de decisão, poderá não resultar nos benefícios esperados (OLIVEIRA, 2008).

Assim, a implementação de uma AAE mais consistente e mais vinculada ao planejamento impõe a horizontalidade entre temas e ações e uma unidade das questões ambientais com referências e informações nas diversas áreas e nos processo decisórios, bem como a verticalidade para níveis hierárquicos inferiores (OLIVEIRA, 2008). A Figura 14 apresenta o procedimento desejável, possibilitado pela $A A E$, considerando a interface com outras estratégias de planejamento. 


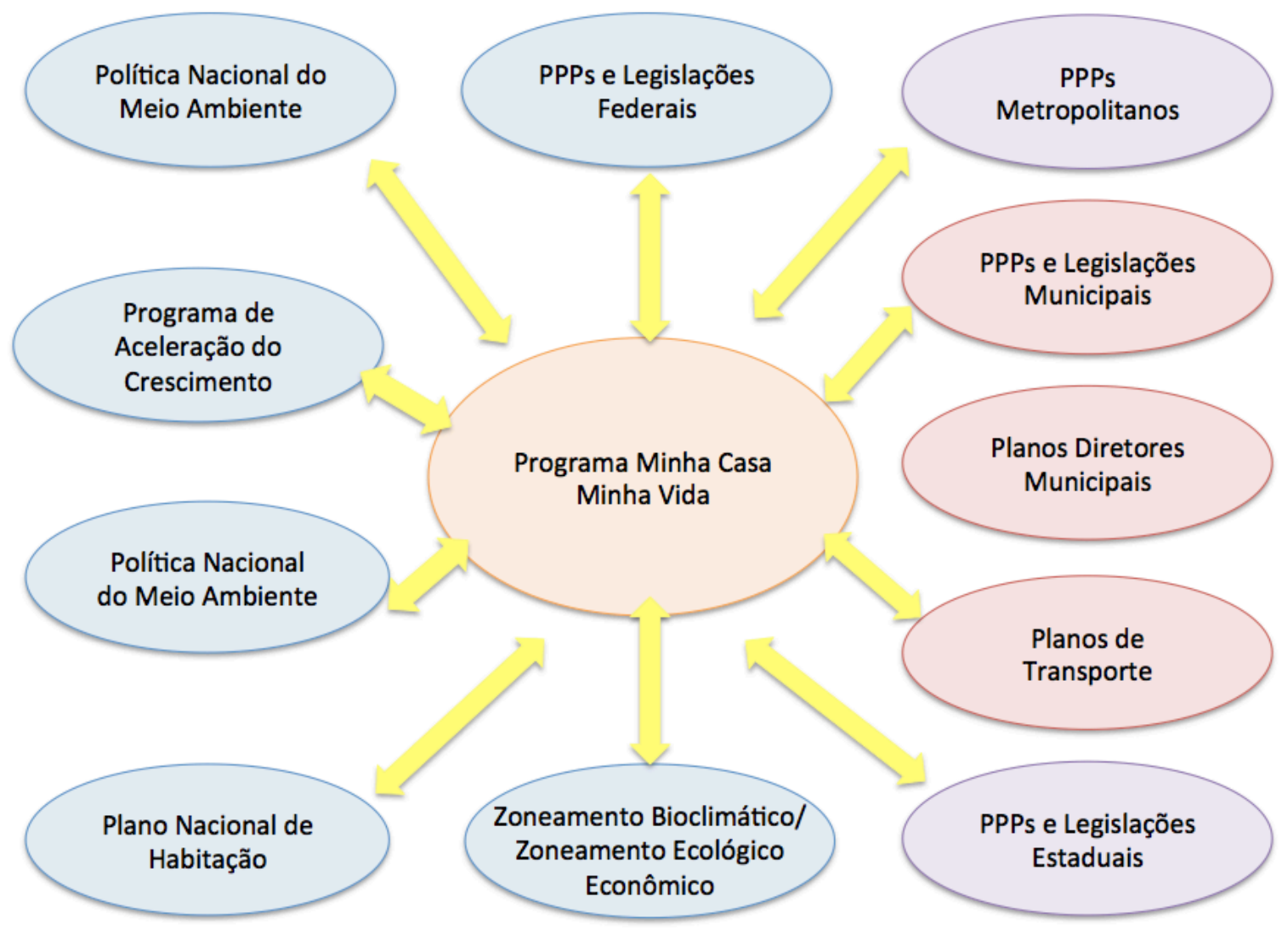

Fonte: Elaborado pela autora.

Essa interface entre as diversas Políticas, Planos e Programas é possibilitada pela AAE por meio da análise entre a ação proposta e outras estratégias de desenvolvimento delineadas para o território em questão, na forma de PPPs (THERIVEL, 2004).

Assim, presume-se que a AAE aplicada de forma integrada à decisão estratégica inclua as possíveis decisões referentes ao nível estadual e municipal, como a definição de tipologias e técnicas construtivas que poderiam ser adaptadas às características climáticas das regiões estabelecidas no Zoneamento Bioclimático Brasileiro ou os aspectos locacionais do PMCMV, que poderiam ser estabelecidos nos planos diretores municipais.

A possibilidade de utilizar a AAE como elo de integração entre diferentes planos e atores pode contribuir para a tomada de decisão com base nas informações ambientais. No caso do PMCMV estão envolvidos diferentes órgãos setoriais da administração pública, empreendedores da iniciativa privada, 
representantes da sociedade civil organizada e agentes da sociedade em geral.

Estabelecendo essa interface entre os diferentes níveis de decisão e PPPs percebemos que AAE deve ser colocada ao longo do processo de planejamento do Programa, podendo ser na esfera das decisões que são de competencia federal, estadual ou municipal. No caso do PMCMV, a AAE deveria ter sido inicialmente aplicada na elaboração do Programa, ou seja, no nível de decisão Federal.

A articulação e integração entre os diferentes PPPs é um grande desafio da sustentabilidade brasileira. Adotar uma visão integrada e multi-direcional, associada aos outros planos e programas, pode contribuir para as decisões e para o processo de planejamento e gestão integrada dos múltiplos interesses da cidade (OLIVEIRA et. al, 2009).

Estabelecer o contexto e a foco estratégico, segundo Partidário (2012) é a prioridade de um ciclo de AAE. A finalidade é assegurar que a AAE se concentre apenas no que é importante, que compreenda e se adapte ao contexto natural, social, cultural, político e econômico do PMCMV.

Assim, sugerem-se quatro elementos fundamentais que contribuiriam para a definição do contexto e do foco estratégico da avaliação:

- Quadro problema: mapeia os principais problemas, potencialidades e forças motrizes que refletem as prioridades setoriais, ambientais e de sustentabilidade. É vital a sua identificação nas fases iniciais, mas não de forma muito detalhada. Isto permite um breve diagnóstico sobre o uso dos recursos naturais, valores naturais, valores culturais, áreas sensíveis, necessidades sociais e bens naturais e sociais com valor econômico de curto, médio e longo prazo.

- Quadro de governança: inclui a identificação da rede de agentes interessados relevantes para a AAE. Identifica quem é quem na implementação de uma política, plano ou programa, e quais as respetivas responsabilidades. Estabelece os direitos e obrigações para uma responsabilidade partilhada

- Quadro de referência estratégica: refere-se ao conjunto das macropolíticas que vão estabelecer o referencial para a avaliação na AAE. Fornece as metas e orientações de longo prazo em relação ao ambiente e sustentabilidade que devem ser observadas pela iniciativa estratégica. Onde for relevante, particularmente em contextos territoriais, os planos e programas relacionados devem ser tidos em consideração.

- Quadro de avaliação: inclui os fatores críticos de decisão, os critérios de avaliação que especificam esse fatores e os indicadores que atuam como métricas da avaliação.

Para o PMCMV podemos estabelecer um hipotético Quadro Problema, de Governança e de Referência Estratégica que ajude a ilustrar a aplicação da AAE (QUADROS 5, 6 e 7). 
QUADRO 5: QUADRO PROBLEMA PMCMV

\begin{tabular}{|c|}
\hline Quadro Problema \\
\hline PRINCIPAIS PROBLEMAS \\
\hline DEGRADAÇÃO AMBIENTAL \\
\hline $\begin{array}{l}\text { Drenagem urbana } \\
\text { Erosão } \\
\text { Poluição do ar } \\
\text { Poluição da água } \\
\text { Resíduos sólidos }\end{array}$ \\
\hline VULNERABILIDADE SÓCIO-AMBIENTAL \\
\hline $\begin{array}{c}\text { Exclusão e segregação social } \\
\text { Pobreza } \\
\text { Àreas de risco } \\
\text { Inundações } \\
\text { Baixa capacitação técnica } \\
\text { Baixa capacidade de infraestrutura urbana } \\
\text { Mobilidade }\end{array}$ \\
\hline PRESSÃO SOBRE OS RECURSOS \\
\hline $\begin{array}{c}\text { Investimentos em grande escala e mal planejados } \\
\text { Urbanização desordenada - Periferização } \\
\text { Uso e ocupação do solo mal planejados }\end{array}$ \\
\hline PRINCIPAIS SENSIBILIDADES \\
\hline VALORES NATURAIS, SOCIAIS E CULTURAIS \\
\hline $\begin{array}{l}\text { Áreas de Proteção Permanente } \\
\text { Áreas centrais e consolidadas }\end{array}$ \\
\hline PRINCIPAIS POTENCIALIDADES \\
\hline $\begin{array}{c}\text { Habitação social para a faixa de renda mais baixa } \\
\text { Empregos } \\
\text { Investimentos em novas tecnologias } \\
\text { Recuperação de vazios urbanos }\end{array}$ \\
\hline
\end{tabular}

Fonte: Modificado de Partidário (2012)

\section{QUADRO 6: QUADRO DE GOVERNANÇA PMCMV}

\begin{tabular}{|l|l|}
\hline \multicolumn{2}{|c|}{ Quadro de Governança } \\
\hline \multicolumn{1}{|c|}{ Grupos de interesse } & \multicolumn{1}{|c|}{ Áreas de Competência e responsabilidade } \\
\hline $\begin{array}{l}\text { Governo Federal } \\
\text { Governo Estadual } \\
\text { Escala Metropolitana } \\
\text { Governo Municipal }\end{array}$ & Elaboração do PMCMV. Repasse de recursos \\
Empresas de Construção & - \\
Público & Cadastramento de interessados e doação de terreno \\
Movimentos Sociais & Execução dos projetos do Programa \\
\hline
\end{tabular}

Fonte: Modificado de Partidário (2012) 
QUADRO 7: QUADRO DE REFERÊNCIA ESTRATÉGICA PMCMV

\begin{tabular}{|l|l|}
\hline \multicolumn{2}{|c|}{ Quadro de Referência Estratégica } \\
\hline Orientações de ambiente e sustentabilidade: & Metas: \\
\hline $\begin{array}{l}\text { Promover a sustentabilidade social, ambiental e } \\
\text { econômica, preservando áreas com potencial } \\
\text { ambiental e requalificando àreas de vazios urbanos. }\end{array}$ & $\begin{array}{l}\text { Construir 3 milhões de unidades } \\
\text { habitacionais em locais dotados de } \\
\text { infraestrutura urbana, e promover a } \\
\text { economia preservando as questões } \\
\text { ambientais e sociais. }\end{array}$ \\
\hline PPPs Relevantes como referencial para AAE \\
\hline Política Nacional de Habitação \\
Plítica Nacional do Meio Ambiente \\
Plano Nacional de Habitação
\end{tabular}

Fonte: Modificado de Partidário (2012)

O papel do Programa nessa perspectiva de desenvolvimento sustentável deve estar associado às necessidades econômicas e sociais conectadas à capacidade ambiental de longo prazo, refletir a relação entre as cidades, o entorno e a expansão e diversidade do uso do solo, do consumo de energia e o aumento dos impactos (OLIVEIRA, 2008).

A AAE presta-se, sobretudo a integrar a PPP em questão com as demais políticas públicas setoriais, através da inserção da avaliação de aspectos ambientais nos processos de tomada de decisão, de modo a garantir que as preocupações ambientais sejam levadas em consideração o mais cedo possível (SEMAD, 2006).

A aplicação da $A A E$ relacionada à ação estratégia em estudo se dá em razão do PMCMV se configurar como uma opção de desenvolvimento, que necessita ter seus riscos e benefícios analisados perante outras opções, sendo que a decisão final deve atender o desenvolvimento sustentável, nos princípios de equidade social, desenvolvimento econômico e proteção ambiental. De acordo com Pizella (2010), trata-se de uma ferramenta que pode minimizar a predominância de interesses setorizados. As questões que poderiam ser tratadas em procedimentos de AAE na busca por alternativas de planejamento do PMCMV estão no Quadro 8.

Um dos aspectos essenciais para avançar nas questões ambientais no processo de planejamento de programas habitacionais envolve o planejamento físico de uso do território. O processo, segundo Teixeira (2008), carece de uma abordagem integrada de planejamento do uso do território, no qual as prioridades e as condicionantes setoriais e ambientais estejam previamente estabelecidas.

Além dos dados coletados, importantes para a proposta em questão, é necessário que as 
informações sejam analisadas espacialmente. A partir da sobreposição de mapas temáticos, tais como características climáticas, déficit habitacional por região, malha urbana, dentre outros necessarios e da ponderação dos fatores ambientais levantados, pode-se indicar espacialmente as áreas mais adequadas à implantação do Programa.

Ao realizar as interfaces com outras PPPs, a etapa de construção da base ambiental é um elemento chave do processo de $\mathrm{AAE}$, por permitir uma avaliação sistemática das informações ambientais relevantes que possibilitem a identificação de problemas ambientais e sócio-econômicos reais ou potenciais da ação proposta em territórios amplos (THERIVEL, 2004). Por meio da existência de informações ambientais sistematizadas na base ambiental, a equipe técnica multidisciplinar pode estabalecer as áreas mais adequadas à implementação do PMCMV, utilizando os indicadores da AAE.

A AAE vai considerar a melhor alternativa em termos de localização, podendo orientar o PMCMV a considerar as dimensões ambientais, sociais e econômicas para a definição das áreas onde seria implantado. Assim, a avaliação dos efeitos cumulativos e sinérgicos que poderiam incidir em longo e médio prazo nas áreas onde o programa será inserido seria viabilizada, e diferentes cenários poderiam ser elaborados.

QUADRO 8: QUESTÕES SETORIAIS A SEREM TRATADAS PELA AAE NO PMCMV

\begin{tabular}{|c|c|}
\hline Escopo do Programa & Questões que poderiam ser tratadas pela $\mathrm{AAE}$ \\
\hline \multicolumn{2}{|c|}{ Objetivos e características gerais } \\
\hline $\begin{array}{l}\text { Impulsionar a economia brasileira através de aumento dos } \\
\text { investimentos no setor da construção civil e reduzir o déficit } \\
\text { habitacional para famílias de baixa renda. }\end{array}$ & $\begin{array}{c}\text { O que se pretende alcançar em termos de provisão } \\
\text { habitacional e metas ambientais? Quais os objetivos de } \\
\text { sustentabilidade (social, econômica e ambiental) associados? }\end{array}$ \\
\hline \multicolumn{2}{|c|}{ Oferta e Demanda } \\
\hline $\begin{array}{c}\text { Construir } 1 \text { milhão de unidades habitacionais na fase } 1 \text { e } 2 \\
\text { minhões na fase } 2 \text { para um déficit atual de } 5.546 .310 \text { de } \\
\text { moradias. }\end{array}$ & $\begin{array}{l}\text { Qual a perspectiva de aumento da demanda por habitações? } \\
\text { Qual o perfil da população e região atingida (avaliar as } \\
\text { necessidades dos futuros moradores, considerando a sua } \\
\text { origem, composição familiar e localização de suas atividades } \\
\text { de trabalho e educação, além das características climáticas } \\
\text { da região)? Qual a influência desses costumes na tipologia e } \\
\text { localização das moradias? }\end{array}$ \\
\hline \multicolumn{2}{|c|}{ Localização } \\
\hline $\begin{array}{l}\text { Critérios locacionais e zoneamento estabelecidos pelo poder } \\
\text { público municipal e agentes privados (construtoras). }\end{array}$ & $\begin{array}{c}\text { Distribuição espacial do PMCMV. } \\
\text { Qual é o grau de desenvolvimento habitacional que as áreas } \\
\text { podem suportar a fim de manter o estado desejado das } \\
\text { condições ambientais? Quais são as áreas que precisam ser } \\
\text { protegidas? Quais são as áreas onde se pode apoiar o } \\
\text { desenvolvimento? Quais são os critérios para a escolha } \\
\text { dessas áreas? Quais os critérios para definição de áreas } \\
\text { prioritárias para implementação? }\end{array}$ \\
\hline
\end{tabular}


Caso a construção de novas moradias em áreas desprovidas de equipamentos e serviços seja uma alternativa válida, a AAE preverá o aumento da rede de infraestrutura e seus possíveis impactos auxiliando, também, na seleção de medidas mitigadoras.

Ao definir o contexto de avaliação das questões ambientais e os horizontes espaciais e temporais das ações propostas, o uso da AAE estabelece as bases necessárias para a análise das atividades propostas e o meio ambiente, possibilitando maior acerto na proposição de usos do território, segundo os interesses da sociedade.

No planejamento do PMCMV, a AAE pode incluir as questões ambientais na elaboração do programa e articulá-las às questões sociais e econômicas. Além disso, pode auxiliar na escolha de alternativas ambientalmente mais adequadas para atingir os principais objetivos.

O desafio de inserir o instrumento AAE encontra-se na prática atual de abordagem da variável ambiental na tomada de decisão. Para tanto, é necessário definir um modelo para a aplicação deste instrumento no ciclo de planejamento das atividades do PMCMV.

De acordo com os critérios e diretrizes apresentados, o modelo proposto na Figura 15 ilustra a proposição de uma estratégia do PMCMV com as potenciais contribuições de aplicação da AAE.

Assim, as principais potencialidades da AAE em auxiliar uma tomada de decisões que insira a variável ambiental e considere os interesses dos diversos setores sociais envolvidos no processo de planejamento do PMCMV são:

- Integrar os aspectos ambientais no momento do planejamento das ações públicas, fazendo com que os tomadores de decisões passem a olhar e avaliar os efeitos ambientais do PMCMV e as suas soluções alternativas, possibilitando a escolha de decisões ambientalmente sustentáveis;

- Avaliar os custos e benefícios de longo prazo (ambientais, sociais e econômicoas) do PMCMV;

- Possibilitar ao Governo uma visão estratégica de longo prazo;

- Avaliar os impactos ambientais em uma escala abrangente e de longo prazo, considerando os efeitos cumulativos e sinérgicos da atuação de múltiplos empreendimentos em uma determinada região, superando as limitações da Licença Ambiental Simplificada, já que amplia o campo de aplicação da avaliação do simples empreendimento para o setor estratégico;

- Maior facilidade de fiscalização e aprovação adequada de projetos pelos órgãos ambientais, uma vez que serão implantados de acordo com as PPPs elaboradas e subsidiadas pela AAE;

- Permitir a participação e influência da sociedade na definição dos objetivos e ações estratégicas do PMCMV;

- Selecionar a alternativa ambiental, econômica e socialmente adequada a ser implementada, sendo possível, inclusive, modificar os objetivos do PMCMV; 
FIGURA 15: INSERÇAO DA AAE NO PMCMV.
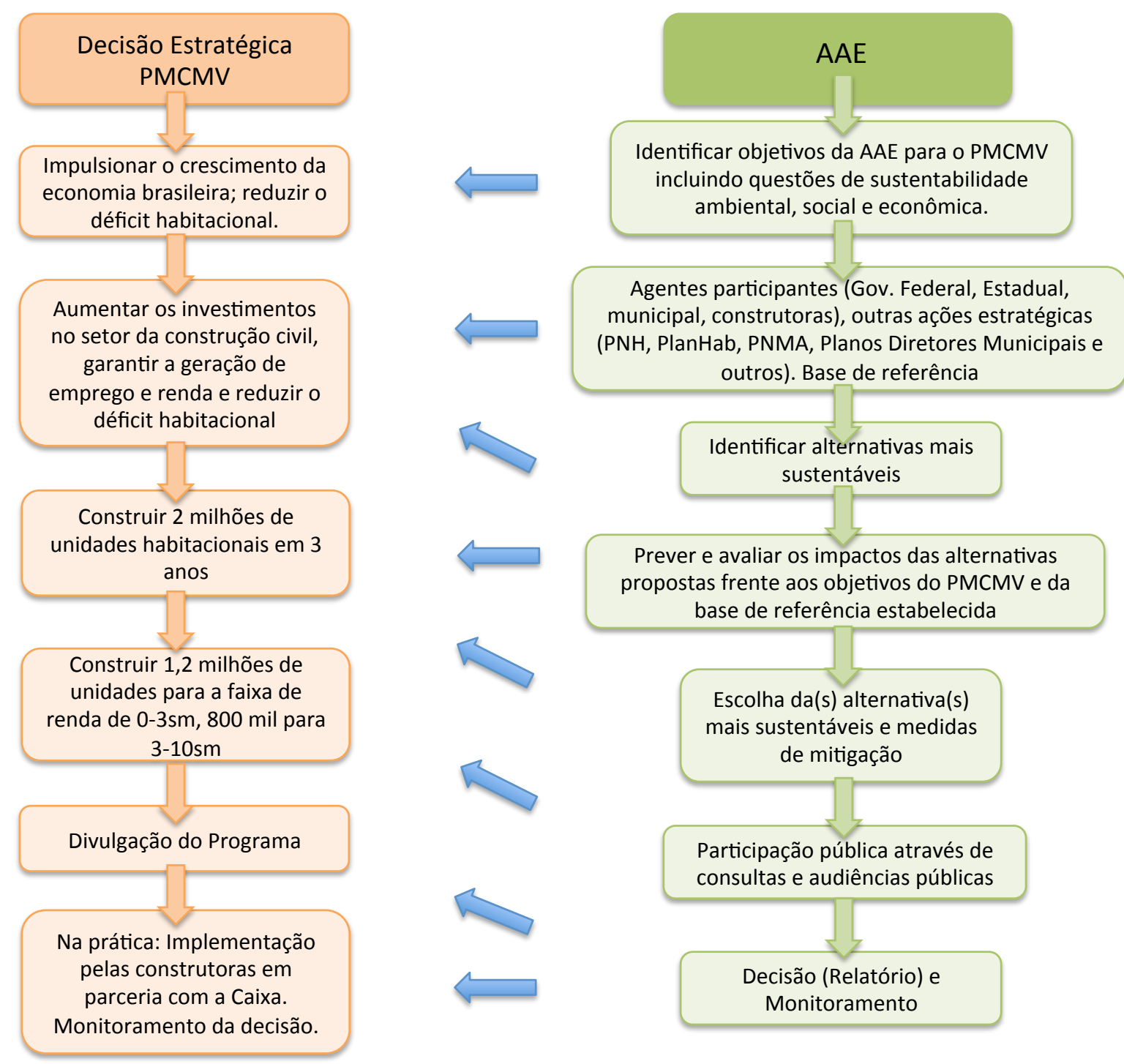

Fonte: Modificada de Therivel (2004)

- Estabelecer medidas mitigadoras para os possíveis efeitos das alternativas selecionadas;

- Induzir a formação de um banco de dados de informações ambientais para o próprio governo;

- Favorecer os tomadores nas escolhas ambientalmente corretas, reduzindo a possibilidade de tomadas de decisões meramente políticas e que possam causar significativos danos ao meio ambiente. Segundo o MMA (2002), se a AAE for implementada em governos que não sejam comprometidos com uma política de sustentabilidade ambiental, poderá tornar-se mais um instrumento inconsistente de gestão ambiental, não gerando os efeitos positivos desejados;

- Por meio da existência de informações ambientais sistematizadas na base de referência, é possível selecionar as alternativas mais sustentáveis, podendo influenciar a definição de 
alternativas locacionais, já que os estudos ambientais, sociais e econômicos necessitam levar em conta as especificidades locais, subsidiando a tomada de decisão;

- A AAE promove um monitoramento ambiental contínuo para as PPPs em relação aos objetivos ambientais e de compatibilidade introduzidos, que pode conduzir, inclusive, à modificação da ação estratégica e da própria AAE realizada ao longo do tempo;

- A realização de uma AAE que contemple o PMCMV permitiria inserir a variável ambiental logo nas primeiras etapas de elaboração do Programa;

- Possibilitar a interação com outras PPPs nacionais, estaduais e municipais. Os objetivos do programa poderiam ser integrados aos objetivos das diferentes PPPs, promovendo assim a conexão com outros instrumentos de planejamento.

Esta integração aproximaria as alternativas possíveis de serem realizadas dos objetivos de sustentabilidade social, econômica e ambiental, atribuindo as considerações dessas dimensões no processo de formulação do PMCMV.

Além disso, é importante destacar que a AAE precisa incluir os diferentes grupos envolvidos nos impactos ambientais em questão e, segundo Costa et. al. (2009) a participação dos atores pode ser garantida por mecanismos como consultas públicas, audiências, entrevistas, seminários, discussões.

A participação permite que os órgãos responsáveis pelas decisões atentem para aspectos que vão além do PMCMV, visando os interesses da coletividade na busca por um equilíbrio ambiental, efetivando a função social da propriedade urbana.

O processo de consulta à sociedade seria fortalecido pela disponibilização e sistematização das informações coletadas. Desta maneira, os diferentes setores da sociedade poderiam defender seus interesses, respaldados pelas diferentes percepções ambientais, considerando as interações dos fatores sociais e econômicos (FABBRO NETO, 2010).

Assim, pode-se concluir que a possibilidade de aplicação da AAE para o PMCMV, por fazer a interface entre as diferentes PPPs e legislações, permite um melhor balanceamento entre as diversas visões sociais e contribui para a prática de uma boa governança ambiental. Isso ocorre por se tratar de uma ferramenta que possui impliçções ambientais, sociais, culturais e econômicas, com potencial de suscitar impactos ambientais cumulativos e indiretos (PIZELLA, 2010).

Através do Quadro 9, pode-se perceber as diferenças de implementação do PMCMV possibilitadas caso a AAE fosse aplicada. Nota-se a importância da elaboração de ações que levem ao desenvolvimento urbano onde todos os aspectos do PMCMV sejam planejados sem passar por cima dos aspectos ambientais e sociais. 
A possibilidade de opções alternativas faz com que a AAE possa percorrer e interagir horizontalmente com diferentes setores e, verticalmente, com níveis distintos de decisão, além de conciliar diferentes temas sem perder o foco ambiental dos PPPs. Assim, não é muito eficiente que esta questão, que envolve a consecução de objetivos estratégicos de desenvolvimento, fique limitada à decisão da esfera do licenciamento ambiental.

QUADRO 9: COMPARAÇÕES ENTRE O PMCMV ATUAL E COM A POSSIBILIDADE DE APLICAÇÃO DA AAE.

\begin{tabular}{|c|c|c|}
\hline \multicolumn{3}{|c|}{ Quadro comparativo } \\
\hline Escopo & PMCMV Atual & PMCMV com AAE \\
\hline Objetivos & $\begin{array}{l}\text { Contribuir para a redução do déficit habitacional } \\
\text { brasileiro, aumentar os investimentos no setor } \\
\text { da construção civil e garantir a geração de } \\
\text { emprego e renda. }\end{array}$ & $\begin{array}{l}\text { Contribuir para a redução do déficit habitacional } \\
\text { brasileiro, aumentar os investimentos no setor } \\
\text { da construção civil e garantir a geração de } \\
\text { emprego e renda incluindo as questões } \\
\text { ambientais e de sustentabilidade. }\end{array}$ \\
\hline Agentes & $\begin{array}{l}\text { Governo Federal (Caixa e Ministério da Fazenda); } \\
\text { Governos municipais; Construtoras, Movimentos } \\
\text { Sociais. }\end{array}$ & $\begin{array}{l}\text { Governo Federal (Caixa, Ministério das Cidades, } \\
\text { Ministério da Fazenda, Ministério do Meio } \\
\text { Ambiente e outros), Governo Estadual, } \\
\text { Municipal, Movimentos Sociais e Construtoras. }\end{array}$ \\
\hline $\begin{array}{l}\text { Avaliação } \\
\text { Ambiental }\end{array}$ & LS por empreendimento & $\begin{array}{l}\text { AAE do Programa antes da LS por } \\
\text { empreendimento }\end{array}$ \\
\hline $\begin{array}{l}\text { Interface com } \\
\text { outras PPPs }\end{array}$ & PAC & $\begin{array}{l}\text { PAC, PNH, PlanHab, Política Nacional do Meio } \\
\text { Ambiente, PPPs Estaduais (meio ambiente, } \\
\text { saúde, educação, Regiões Metropolitanas), PPPs } \\
\text { Municipais (planos Diretores, transportes) e } \\
\text { outras PPPs setoriais. }\end{array}$ \\
\hline Localização & À critério das construtoras & $\begin{array}{l}\text { Pré estabelecida na elaboração do PMCMV por } \\
\text { meio da base de referência ambiental e interface } \\
\text { com outras PPPs. }\end{array}$ \\
\hline $\begin{array}{l}\text { Participação } \\
\text { Pública }\end{array}$ & $\begin{array}{l}\text { Somente através das entidades/movimentos } \\
\text { sociais em casos específicos }\end{array}$ & $\begin{array}{l}\text { Consultas, audiências públicas antes da tomada } \\
\text { final de decisão }\end{array}$ \\
\hline Avaliação & $\begin{array}{l}\text { Caixa avalia apenas os projetos do Programa. O } \\
\text { PMCMV em si é avaliado apenas através do } \\
\text { número de unidades habitacionais. }\end{array}$ & $\begin{array}{l}\text { Avaliação constante do Programa através do } \\
\text { monitoramento definido pela AAE, podendo, } \\
\text { inclusive, modificar os objetivos do PMCMV ou } \\
\text { da própria AAE ao longo do tempo. }\end{array}$ \\
\hline
\end{tabular}

Fonte: Elaborado pela autora.

Dessa forma, algumas diretrizes devem ser impostas na prática da AAE em programas habitacionais: 
Devem ser estabelecidos critérios mínimos para garantir a participação e o envolvimento da sociedade, a integração dos processos, formas de divulgação, incorporação dos resultados da $\mathrm{AAE}$, prazos etc.

O PMCMV 2 tem escala nacional e um horizonte temporal de 3 anos, e trata da questão habitacional de modo abrangente. Questões como a regionalização das moradias, ampliação dos serviços e equipamentos de infraestrutura, integração com outros sistemas e programas urbanos não são tratados de maneira adequada. É preciso ajustar o escopo e o nível de detalhamento das informações do processo de AAE ao grau de relevância dessas questões frente à base ambiental e às demais escalas (nacional, regional e local).

É preciso garantir que AAE seja capaz de oferecer evidências claras das suas contribuições ao processo de planejamento e seu impacto no conteúdo das PPPs, inclusive no que diz respeito às contribuições provenientes da participação pública e articulação entre instituições, planejadores e avaliadores (LEMOS, 2011). A AAE deve aperfeiçoar a rotina de planejamento das instituições, auxiliando o processo de planejamento e deve causar impactos positivos na qualidade ambiental do PMCMV.

O propósito de adoção da AAE no planejamento do PMCMV também é permitir que os potenciais impactos e riscos ambientais estratégicos associados à introdução ou ao incremento das atividades relacionadas à provisão habitacional em novas áreas sejam avaliados numa perspectiva estratégica, e não numa abordagem operacional, por uma estrutura de governança pública própria para a tomada de decisão.

O fato das etapas estratégicas do PMCMV conduzirem e delinearem os empreendimentos pontuais, fazem da AAE uma ferramenta que possibilita a avaliação desses e pode ser capaz de influenciar as tipologias e localizações dos projetos futuros, ao invés de avaliá-los somente após sua concepção.

Nesse sentido, a AAE é necessária ao desenvolvimento de ações estratégicas do PMCMV pois permite uma análise sistemática dos objetivos pretendidos de forma independente, considerando a análise de outras ações estratégicas relacionadas e diminuindo possíveis confrontos existentes.

Embora a AAE seja um caminho necessário para garantir os objetivos dos PPPs e o vínculo ao planejamento e ao processo decisório, a prática ambiental no país ainda não é tratada da mesma maneira que nos outros temas associados às questões econômicas e sociais.

De acordo com Oliveira (2008), garantir a AAE no Brasil significa garantir seus pressupostos, seus objetivos, metas e resultados integrando e interagindo com outros instrumentos e não tomando o lugar destes. 
FINAL

CONSIDERAÇÕES FINAIS 
O objetivo deste trabalho consistiu em analisar as possíveis contribuições da Avaliação Ambiental Estratégica para a tomada de decisões sobre as Poíticas, Planos e Programas habitacionais, investigando o Programa Minha Casa Minha Vida.

O estudo em questão permitiu estabelecer algumas considerações sobre o PMCMV e a AAE como instrumento de planejamento ambiental.

A desarticulação entre o PMCMV e demais políticas urbanas desconsiderando as questões ambientais e de sustentabilidade provoca a provisão de grandes empreendimentos habitacionais destinados à população de baixa renda em áreas inóspitas e distantes dos grandes centros urbanos, com mobilidade urbana e acesso à infraestrutura precários.

O papel dado às construtoras como agente decisor sobre os projetos do Programa em questão criam um padrão de expansão urbana periférica, agravando problemas como transporte e mobilização urbana.

O entendimento compartilhado por diferentes autores como Bonduki (2008), Rolnik (2010), Maricato (1996) é de que o acesso à moradia digna está diretamente relacionado à capacidade de ampliação e disponibilização de terra urbanizada bem localizada.

Entretanto, o impulso na oferta habitacional causado pelo PMCMV teve sérias conseqüências também na demanda por novas terras urbanas edificáveis.

Mesmo com o histórico de PPPs habitacionais brasileiros, permanece no PMCMV a mesma lógica de funcionamento do $\mathrm{BNH}$, estruturado pelo aumento do consumo da moradia e pela garantia do trabalho das construtoras.

No caso do PMCMV, nenhum instrumento de estudo ambiental foi adotado nos processos decisórios, desconsiderando diversos critérios fundamentais para a identificação e avaliação de seus impactos potenciais, tanto positivos quanto negativos, como: as alternativas tecnológicas; as alternativas locacionais, já que o Programa não considera as particularidades ambientais, sociais e econômicas brasileiras; a compatibilidade com as legislações e PPPs relacionadas.

Entretanto, a variável ambiental é uma das condicionantes determinantes para a tomada de decisão sobre quais os cenários mais apropriados devem ser desenvolvidos para atender os objetivos sociais e econômicos do PMCMV. Os aspectos ambientais, sociais e econômicos são abordados conjuntamente na AAE o que permite aos tomadores de decisão uma visão ampla e integrada das convergências e divergências em torno das opções de cenários. 
A AAE auxilia na escolha da melhor opção para o meio ambiente, propondo alternativas locacionais, considerando diferentes alternativas visando os mesmos objetivos, inclusive a opção de não adotar a estratégia,

Nesse caso, a AAE pode constituir uma importante ferramenta para agregar qualidade à avaliação do PMCMV por permitir questionar não só os resultados, mas também os fundamentos do Programa.

Algumas características da AAE mostraram-se adequadas para a avaliação do PMCMV na pesquisa, pois:

· O PMCMV não é uma atividade pontual, pois abrange todo o território nacional,

- O PMCMV é uma ação estratégica com potencial de ocasionar impactos ambientais em larga escala, cumulativos, indiretos e de longo prazo, tanto ambientais como sociais e econômicos.

- Faz parte de um programa governamental de desenvolvimento do setor habitacional que se relaciona com outras Leis e PPPs. Portanto, estas devem ser consideradas em qualquer processo de tomada de decisão.

- Uma das funções da AAE é a avaliação dos impactos ambientais cumulativos, indiretos e de longo prazo de PPPs, que abrangem recortes territoriais amplos.

- Alguns casos em evidências, relacionados às PPPs habitacionais, demonstram o potencial de se utilizar a AAE para sua avaliação.

- As alternativas tecnológicas também são contempladas na $A A E$, especialmente em se tratando de estratégias de desenvolvimento, como no presente caso.

- A participação social é crucial para a realização de uma AAE com legitimidade.

- A rotina de monitoramento da ação estratégica é condicionante para uma boa prática de $A A E$, trazendo contribuições significativas para o tratamento do caso em questão

Deste modo, pôde-se concluir que a sistemática da AAE para implementar os princípios do desenvolvimento sustentável no PMCMV é, senão essencial, recomendável para a tomada de decisão, já que considera as variáveis ambientais sociais e econômicas nas etapas de planejamento. 


\section{REFERÊNCIAS BIBLIOGRÁFICAS}

ABIKO, A. K. Introdução à Gestão Habitacional. Texto Técnico da Escola Politécnica da Universidade de São Paulo. Departamento de Engenharia de Construção Civil. São Paulo, 1995.

AGRA FILHO, S. S. Avaliação Ambiental Estratégica - uma alternativa de incorporação da questão ambiental no processo de desenvolvimento. Tese (Doutorado). Instituto de Economia, Universidade de Campinas, 2002. 247p.

ALMEIDA, M. de; AMATO, F. B. Empreendimentos para Baixa Renda - Programa "Minha Casa -Minha Vida". 11a Conferência Internacional da LARES.São Paulo, 2011. Disponível em: <www.lares.org.br/2011/images/530-741-1-RV.pdf>.Acesso em 07/10/2011.

ANDRADE, N. A. et.al. Planejamento governamental para municípios: plano plurianual, lei de diretrizes orçamentárias e lei orçamentária anual. São Paulo: Atlas, 2005.

ANDRÉ, P. et al. L'Évaluation des Impacts sur l'Environnement - Processus, Acteurs et Pratique. Canadá: Presses Internationales Polytechnique, 1999.

ARANTES, P. F., FIX, M. Como o governo Lula pretende resolver o problema da habitação. Alguns comentários sobre o pacote habitacional Minha Casa, Minha Vida. Correio da Cidadania. 01 ago. 2009. Disponível em: <www.correiocidadania.com.br> Acesso em: 15/09/2010.Artigo recebido via email pelo autor.

BASTOS, R. M. ECONOMIA POLÍTICA DO IMOBILIÁRIO: O PROGRAMA MINHA CASA MINHA VIDA E O PREÇO DA TERRA URBANA NO BRASIL. Dissertação de Mestrado da Unicamp. Campinas, 2012.

BONDUKI, N. Origens da habitação social no Brasil. São Paulo: Estação Liberdade, 1998

BONDUKI, N. Planejamento habitacional no Brasil: dilemas, avanços e perspectivas (SL 19). XIII ENANPUR - Florianópolis, 25-29 maio de 2009.

BONDUKI, N. Política Habitacional e Inclusão Social No Brasil: Revisão Histórica e Novas Perspectivas no Governo Lula. Revista eletrônica de Arquitetura e Urbanismo, num. 1, Universidade São Judas Tadeu. 2008.

BRASIL. Constituição Federal de 1988.

BRASIL. Estatuto da Cidade. Lei no 10.257, de 10 de julho de 2001. Disponível em: <https://www.planalto.gov.br/ccivil_03/Leis/LEIS_2001/L10257.htm> Acesso em 27/08/2010.

BRASIL. Lei Federal no 5.107, de setembro de 1966 
BRASIL. Lei Federal no 11.977, de 7 de julho de 2009 . Disponível em: <http://www.planalto.gov.br/ccivil_03/_Ato2007-2010/2009/Lei/L11977.htm>. Acesso em 03/02/2011.

BRASIL. Medida Provisória no 459, de 25 de março de 2009 . Disponível em: <http://www.planalto.gov.br/ccivil_03/_Ato2007-2010/2009/Mpv/459.htm>. Acesso em 03/02/2011.

BRASIL. Resolução CONAMA 01 de 1986

BRASIL. Resolução CONAMA n. 237, de 19/12/1997

BRASIL. Resolução CONAMA no 412, de 13 de maio de 2009.

BURGESS, R.; CARMONA, M.; \& KOLSTEE, T. - The challenge of Sustainable cities. Neoliberalism and urban strategies in developing countries - ZED BOOKS - London, 1997;

BURSZTYN, M. A. A. Gestão Ambiental: instrumentos e práticas. Edições IBAMA, Brasília, 1994.

CAIXA ECONOMICA FEDERAL. Programa Minha Casa Minha Vida. Disponível em: <http://www1.caixa.gov.br/gov/gov_social/municipal/programas_habitacao/pmcmv/saiba_mais.asp>. Acesso em 15/04/2010.

CAIXA ECONOMICA FEDERAL. Cartilha Completa Minha Casa Minha Vida. Disponível em: <http://downloads.caixa.gov.br/_arquivos/habita/mcmv/CARTILHACOMPLETA.PDF>. Acesso em $02 / 02 / 2010$.

CAMPOS, P. R.; MENDONÇA, J. G. de. Estrutura socioespacial e produção habitacional na Região Metropolitana de Belo Horizonte: novas tendências. In O programa Minha Casa Minha Vida e seus Efeitos Territoriais. Letra Capital. Rio de Janeiro, 2013.

CARDOSO, A. In BBC BRASIL. Urbanistas elogiam 'Minha Casa', mas criticam ocupação de áreas sem estrutura. Disponível em: <http://www.bbc.co.uk/portuguese/noticias/2011/06/110615_minhacasa_jf.shtml>. Acesso em 10/09/2011

CARDOSO, A. L.; ARAGÃO, T. A. ; ARAUJO, F. S. . Habitação de Interesse Social: política ou Mercado? Reflexos sobre a construção do espaço metropolitano. In: Anais do XIII Encontro Nacional da ANPUR, 2011.

CARDOSO, A. L.; ARAGÃO, T. A. Do fim do BNH ao Programa Minha Casa Minha Vida: 25 anos da política habitacional no Brasil . In: O programa Minha Casa Minha Vida e Seus Efeitos Territoriais. Letra Capital. Rio de Janeiro, 2013.

CARMO, E. C. do. A Politica Habitacional no Brasil Pós Plano Real. Tese de Doutorado Unicamp. Campinas, 2006. 
COELHO, M. C. N. Impactos Ambientais em áreas urbanas - teorias, conceitos e métodos de pesquisa in: GUERRA, A. J. T. \& CUNHA, S. B. (org.) - Impactos ambientais urbanos no Brasil - 2a. Ed - Bertrand Brasil - Rio de Janeiro - 2004.

COELHO, W. R. O Déficit das Moradias: Instrumento para Avaliação e Aplicação de Programas Habitacionais. Dissertação de mestrado EESC, São Carlos, 2002.

COSTA, H. S. de M.; BRAGA, T. M. Entre a Conciliação e o Conflito: Dilemas para o Planejamento e a Gestão Urbana e Ambiental. X Seminário sobre a Economia Mineira, 2010.

COSTA, H. A.; BURSZTYN; M. A. A.; NASCIMENTO, E. P. do. Participação Social em Processos de Avaliação Ambiental Estratégica. Revista Sociedade e Estado, Brasília, v. 24, n. 1, p. 89-113, jan./abr. 2009

CORREIA, M. Avaliação Ambiental Estratégica - Aplicação aos Planos Municipais de Ordenamento do Território. Dissertação de Mestrado FCT/UNL. Lisboa, 2009

CORREIO BRASILIENSE. Recursos para a 2a fase do Minha Casa, Minha Vida podem chegar a R\$ $140 \mathrm{mi}$. Reportagem publicada em 06/06/2011. Disponível em <http://www.correiobraziliense.com.br/ app/noticia/politica-brasil-economia/2011/06/06/internas_polbraeco,255622/recursos-para-a-2-fasedo-minha-casa-minha-vida-podem-chegar-a-r-140-mi.shtml>. Acesso em 02/10/2011.

CUNHA, D. F. ; Borges, E. M.. Habitação planejada como elemento estruturador das cidades: a experiência de Goiás. In: XIV Encontro Nacional da ANPUR. Rio de Janeiro/RJ. Anais do XIV Encontro Nacional da ANPUR, 2011.

DALAL-CLAYTON, B.; SADLER, B. Strategic Environmental Assessment - a sourcebook and reference guide to internatinal experience. Londres, 2005.

D`AMICO, F. O Programa Minha Casa, Minha Vida e a Caixa Econômica Federal. In: O Desenvolvimento Econômico Brasileiro e a Caixa. Trabalhos premiados. Centro Internacional Celso Furtado de Políticas para o Desenvolvimento. Rio de Janeiro, 2010.

DE PASCHOAL, R. Urbanista critica planejamento do pacote habitacional. PiniWeb, São Paulo, 11/05/2009. Disponível em <http://www.piniweb.com.br/construcao/habitacao/urbanistacriticaplanejamento-do-pacote-habitacional-134521-1.asp.>. Acesso em 04/09/2011.

DIAS, E. C. Do Plano Real ao Programa Minha Casa, Minha Vida - Negócios, votos e as reformas da habitação. Dissertação de Mestrado. Universidade de São Paulo. São Paulo, 2012

EGLER, P. C. G.; FILHO, S. S. A. AVALIAÇÃo AMBIENTAL ESTRATÉGICA- AAE - Apostila de Curso no Centro de Recursos Ambientais, 2004 
EGLER, P. C. G. Improving the Environmental Impact Assessment Process in Brazil. Tese de Doutorado, School of Environmental Sciences, University of East Anglia. 1998.

EGLER, P. C. G. Perspectivas de Uso no Brasil do Processo de Avaliação Ambiental Estratégica. Série Educação e Meio Ambiente, MMA, Brasília, 2002.

FABBRO NETO, F. Avaliação Ambiental Estratégica para Planos de Uso e Ocupação do Solo: Um Estudo Sobre o Plano Diretor Municipal. Dissertação de Mestrado. EESC/USP. São Carlos, 2010.

FABBRO NETO, F; SOUZA, M. P. AAE Plano Diretor AVALIAÇÃO AMBIENTAL ESTRATÉGICA E DESENVOLVIMENTO URBANO: CONTRIBUIÇÕES PARA O PLANO DIRETOR MUNICIPAL. Revista Minerva Pesquisa \& Tecnologia. Volume 6, Número 1 - janeiro a abril de 2009

FERNANDES, C. do C. P.; SILVEIRA, S. de F. R. da. Ações e Contexto da Política Nacional de Habitação: Da Fundação Casa Popular ao Programa “Minha Casa, Minha Vida”. II EMAPEGS. Viçosa, 2010

FERNANDES, E. Sobre a importância do Planejamento Urbano na defesa do direito à moradia - Boletim Direito à Moradia e à Cidade na América Latina - COHRE- Centro pelo Direito à Moradia e Contra Despejos - Programa para as Américas- CAP, Ano 1, no 4, 2008.

FERREIRA, L. A questão ambiental: sustentabilidade e políticas públicas no Brasil. São Paulo: Boitempo Editorial, 1998.

FIESP. Caderno Técnico Construbusiness 2010 - Congresso Brasileiro da Construção (9ạ edição). São Paulo, 2010. Disponível em: <http://www.fiesp.com.br/construbusiness/pdf/apresentacoes/ ConstBusiness2010Portugues.pdf>. Acesso em 03/06/2011.

FISCHER, T. B. Strategic environmental assessment in post-modern times. Environmental Impact Assessment Review, v. 23, n. 2, p. 155-170, 2003.

FISCHER, T. B. Strategic environmental assessment and transport planning: towards a generic framework for evaluating practice and developing guidance. Impact Assessment and Project Appraisal, v. 24, n. 3, p. 183-197, 2006.

FISCHER, T. B. Theory \& Practice of SEA. Towards a more systematic approach. Earthscan - Londres, 2007;

FIX, M. Financeirização e transformações recentes no circuito imobiliário no Brasil. Tese de doutorado. IE. Universidade Estadual de Campinas. 2011 
FREITAS, C.G.L. (coord.) et.al.. Habitação e Meio Ambiente: abordagem integrada em empreendimentos de interesse social. Coleção Habitare/Finep. São Paulo: Instituto de Pesquisas Tecnológicas do Estado de São Paulo - IPT, 2001.

FUNDAÇÃO JOÃO PINHEIRO. Déficit Habitacional no Brasil 2008, com dados de 2007 reponderados, 2011. Disponível em: <http://www.fjp.gov.br/index.php/servicos/81-servicos-cei/70-deficithabitacional-no-brasil> Acesso em 12/03/2011.

GREgóRIO, C. Minha Casa Minha Vida 2. Discussão sobre a Atratividade dos Empreendimentos Voltados à Faixa de 0 a 3 SM. Texto para Coluna do NRE-POLI na Revista Construção e Mercado. Outubro 2011.

HIRATA, F. A luta pela moradia em São Paulo. Dissertação de Mestrado Unicamp. Campinas, 2010.

IAIA - INTERNATIONAL ASSOCIATION FOR IMPACT ASSESSMENT (2002). The Linkages between impact assessment and the sustainable development agenda, and recommendations for actions. Disponível em http://www.iaia.org/ . Acesso em 12/08/2012.

IPEA. PNAD 2009 - Primeiras análises: Investigando a chefia feminina de família. Disponível em: <http://www.ipea.gov.br/portal/images/stories/PDFs/comunicado/101111_comunicadoipea65.pdf>. Acesso em 10/09/2011.

JOÃO, E. Key Principles of SEA. In: SCHMIDT, M.; JOÃO, E.; ALBRECHT, E. (Eds.). Implementing Strategic Environmental Assessment. UK: Springer. 2005.

JORNAL DA MANHÃ. Casas de condomínio do Minha Casa Minha Vida são entregues com problemas estruturais. Disponível em: <http://video.globo.com/Videos/Player/Noticias/0,,GIM1598766-7823CASAS+DE+\%20CONDOMINIO+DO+MINHA+CASA+MINHA+VIDA+SAO+ENTREGUES+COM+PROBLEMA S+ESTRUTURAIS,00.html>. Acesso em 09/09/2011.

LANNOY, C. P. de. O Descompasso das Políticas Públicas para a Solução do Déficit Habitacional. Dissertação de Mestrado. Faculdade de Arquitetura e Urbanismo. Universidade de Brasília. 2006 LEE, N.; F. WALSH. 1992. Strategic Environmental Assessment: An Overview. Project Appraisal, Vol. 7, No. 3 .

LEMOS, C. C. Avaliação ambiental estratégica para o setor de turismo: uma proposta para aplicação no Brasil. Tese de Doutorado. EESC. USP. São Carlos, 2011.

MALERONKA, C. PAR-REFORMA: QUEM SE HABILITA? A VIABILIZAÇÃO DE EMPREENDIMENTOS HABITACIONAIS EM SÃO PAULO ATRAVÉS DO PROGRAMA DE ARRENDAMENTO RESIDENCIAL MODALIDADE REFORMA: 1999-2003. Dissertação de Mestrado IPT, São Paulo, 2005. 
MANSUR de M. S, C. Avaliação Ambiental Estratégica (AAE): Limitações dos Estudos de Impacto Ambiental (EIA). In: XVII Simpósio Brasileiro de Recursos Hídricos, 2007, São Paulo. Anais dos XVII Simpósio Brasileiro de Recursos Hídricos. São Paulo : Unius Multimídia Ltda, 2007. v. I.

MANSUR de M. S., Cr; Tomaselli, C. C.; Scheibe, L. F. Avaliação Ambiental Estratégica nos Processos Decisórios de Planejamento Territorial. Anais do XVII Simpósio Brasileiro de Recursos Hídricos, 2007.

MARICATO, E. Metrópole na Periferia do Capitalismo. São Paulo, Hucitec, 1996.

MARICATO, E. O “Minha Casa” é um avanço, mas segregação urbana fica intocada. Disponível em: <http://www.cartamaior.com.br/templates/materiaMostrar.cfm?materia_id=16004>. Acesso em: $27 / 05 / 2011$.

MINISTÉRIO DAS CIDADES. Portaria no 93 de 24 de fevereiro de 2010.

MINISTÉRIO DAS CIDADES. Portaria no 465, de 03 de outubro de 2011.

MINISTÉRIO DAS CIDADES. Programa Minha Casa Minha Vida. Disponível em: < http://www.cidades.gov.br/index.php?option=com_content\&view=article\&id=1131\&ltemid=200> Acesso em 15/09/2010.

MMA - MINISTÉRIO DO MEIO AMBIENTE. Avaliação Ambiental Estratégica. Brasília, MMA/SQA. Disponível em <http://www.mma.gov.br>. Acesso em 16/08/2010

NASCIMENTO, D. M.; TOSTES, S. P.. Programa Minha Casa Minha Vida: a (mesma) política habitacional no Brasil. Arquitextos, São Paulo, 12.133, Vitruvius, jun 2011 <http://www.vitruvius.com.br/revistas/read/arquitextos/12.133/3936>.

OCDE. Aplicação da Avaliação Ambiental Estratégica: Guia de Boas Práticas na Cooperação para o Desenvolvimento, OECD Publishing. 2012. Disponível em http://dx.doi.org/10.1787/9789264175877-pt. Acesso em 02/02/2012.

OLIVEIRA, A. A. de; BURSZTYN, M. Avaliação de impacto ambiental de políticas públicas. Revista Internacional de Desenvolvimento Local. Vol. 2, N. 3, Set. 2001.

OLIVEIRA, I. C. E. de. Estatuto da cidade; para compreender. Rio de Janeiro: IBAM/DUMA, 2001.

OLIVEIRA, I. S. D. Alternativas para a implementação da Avaliação Ambiental Estratégica no Brasil Tese de Doutorado. EESC/USP. São Carlos, 2008.

OLIVEIRA, I. S. D.; MONTAÑO, M.; SOUZA, M. P.. Avaliação Ambiental Estratégica. São Carlos: Suprema, 2009. 
PARTIDÁRIO, M. R. Avaliação Ambiental Estratégica - estudos de impacte ambiental 11 a aula. S.D. Disponível em: <https://dspace.ist.utl.pt/bitstream/2295/80969/1/11.\%20AAE.pdf>

PARTIDÁRIO, M. R. Avaliação Ambiental Estratégica. Brasília. MMA, 2002;

PARTIDÁRIO, M. R. Guia de Melhores Práticas para Avaliação Ambiental Estratégica - orientações metodológicas para um pensamento estratégico em AAE. Lisboa, 2012

PARTIDÁRIO, M. R.; CLARK, R. Perspectives on Strategic Environmental Assessment. Boca Raton: Lewis. 2001.

PARTIDÁRIO, M. R.; JESUS, J. de. Avaliação de impactos ambientais. Portugal: Centro de Estudos de Planejamento e Gestão do Ambiente (CEPGA). 1999.

PELLIN, A.; TACHARD, A.L.; LEMOS, C.C.; OLIVEIRA, I.S.D.; SOUZA, M.P.O. Avaliação ambiental estratégica no Brasil: considerações a respeito do papel das agências multilaterais de desenvolvimento. Engenharia Sanitária Ambiental, Mar 2011, v16, no.1, p.27-36.

PEQUENO, R.; FREITAS, C. Programa Minha Casa Minha Vida em Fortaleza: Primeiros Resultados . In O programa Minha Casa Minha Vida e Seus Efeitos Territoriais. Rio de Janeiro, 2013.

PIRES, L. R. G. M. Função social da propriedade urbana e o plano diretor. Belo Horizonte: Editora Fórum, 2007.

REIS, A. T. da L.; LAY, M. C. D. O projeto da habitação de interesse social e a sustentabilidade social. Revista Ambiente Construído, Porto Alegre, v. 10, n. 3, p. 99-119, jul.;set. 2010. Disponível em: <http://seer.ufrgs.br/index.php/ambienteconstruido/article/viewArticle/12816>. Acesso em $15 / 12 / 2010$.

REVISTA AU. Arquitetura e Urbanismo. Pré-fabricação e montagem manual caracterizam os projetos habitacionais criados por Lelé para o programa Minha Casa, Minha Vida. Edição 208, julho de 2011.

REZENDE, D. A.; ULTRAMARI, C. Plano diretor e planejamento estratégico municipal: introdução teóricoconceitual. Revista Administração Pública, Rio de Janeiro, v. 41, n. 2, Apr. 2007 . Disponível em $<$ http://www.scielo.br/scielo.php?script=sci_arttext\&pid=S0034-76122007000200005\&lng=en\& nrm=iso> . Acesso em 09/12/2011.

ROLNIK, R. Aumento do teto do financiamento do Minha Casa, Minha Vida: evidência preocupante da explosão dos preços dos imóveis. Texto publicado em 03/02/2011. Disponível em: <http://raquelrolnik.wordpress.com/2011/02/03/aumento-do-teto-do-financiamento-do-minha-casaminha-vida-evidencia-preocupante-da-explosao-dos-precos-dos-imoveis-no-brasil/>. Acesso em 04/07/2011. 
ROLNIK, R. (org.); Bischof, R; Klintowitz, D.; Reis, J.. Como produzir moradia bem localizada com recursos do programa minha casa minha vida?: implementando os instrumentos do Estatuto da Cidade. Brasília: Ministério das Cidades, 2010.

ROLNIK, R. Eu sou você amanhã: a experiência chilena e o 'Minha Casa, Minha Vida'2012. Disponível em http://raquelrolnik.wordpress.com/2012/05/10/eu-sou-voce-amanha-a-experiencia-chilena-e-ominha-casa-minha-vida/. Acesso em 10/02/2013

ROLNIK, R.; NAKANO, K.. As armadilhas do pacote habitacional. Le Monde Diplomatique, São Paulo, n. 20, p.4-5, mar. 2009.

SADLER, B.; VERHEEM, R. - Environmental Assessment of Policies: Briefing papers on experience in selected countries - VROM - Holanda, 1996

SACHS, I.. Desenvolvimento: includente, sustentável, sustentado. Rio de Janeiro: Garamond; 2004.

SÁNCHEZ, L. E. Avaliação de Impacto Ambiental: conceitos e métodos. Oficina de Textos - São Paulo, 2006.

SÁNCHEZ, L. E. Avaliação Ambiental Estratégica e sua Aplicação no Brasil. Texto preparado como referência para o debate "Rumos da Avaliação Ambiental Estratégica no Brasil". Universidade de São Paulo, 2008. Disponível em <http:www.iea.usp.br>. Acesso em 13/11/2011.

SANTOS, C. H. M.. Políticas Federais de Habitação no Brasil: 1964/1998. Texto Técnico IPEA. Brasília: julho 1999.

SANTOS, M. Urbanização brasileira. Edusp. São Paulo, 1993.

SANTOS, R. F. dos. Planejamento Ambiental: teoria e prática. São Paulo: Oficina de Textos, 2004.

SCHEIDT, F. S. da S.; SILVA, P. R. da; SILVA,S. M. C. P. da; HIROTA, E. H..Consideração de requisitos ambientais em empreendimentos habitacionais de interesse social: um estudo de caso. Revista Ambiente Construído, Porto Alegre, v. 10, n. 1, jan./mar. 2010.

SEMAD - Secretaria de Estado de Meio Ambiente e Desenvolvimento Sustentável. Apostilia de Avaliação Ambiental Estratégica. 09 de outubro de 2006. Diponível em:

http://www.meioambiente.mg.gov.br/images/stories/coisas/aae_apostila.pdf . Acesso em 10/04/2013.

SHIMIZU, J. Y. Projeção de Impactos Econômicos do Programa Minha Casa, Minha Vida: Uma Abordagem de Equilíbrio Geral Computável. Dissertação de Mestrado da Faculdade de Ciências Econômicas da Universidade Federal de Minas Gerais. Belo Horizonte, MG. 2010 
SILVA, A. T. da; MORO, P. R. P.; PARISI, A. Parâmetros de sustentabilidade e empreendimentos de habitação de interesse social. Congresso Internacional de Sustentabilidade e Habitação de Interesse Social. Porto Alegre, 2010.

SOUZA, M. L. Mudar a cidade: uma introdução crítica ao planejamento e à gestão urbanos. Rio de Janeiro: Bertrand, 2002.

SOUZA, M. P. Instrumentos de Gestão Ambiental: fundamentos e prática - Ed.Riani Costa. São Carlos, 2000.

SPINOLA, R.M.G.; ABIKO, A.ZEIS: o interesse social das Zonas Especiais para a habitação popular, aplicadas no município de Santos/SP, Brasil. Anais do 4o. Congresso Luso-Brasileiro para o Planejamento Urbano, Regional, Integrado e Sustentável. Pluris 2010

TASCHNER, S.P. Família, habitação e dinâmica populacional no Brasil atual: notas muito preliminares. In: GORDILHO SOUZA, A. Habitar contemporâneo: novas questões dos anos 90. Salvador: UFBa; FAUFBa; LAB Habitar, 1997.

TEIXEIRA, I. M. V. O uso da avaliação ambiental estratégica no planejamento da oferta de blocos para exploração e produção de petróleo e gás natural no Brasil: uma proposta. Tese de doutorado. UFRJ. Rio de Janeiro, 2008

THÉRIVEL, R. Environmental Impact Assessment Review. Oxford, 1999.

THÉRIVEL, R. Strategic Environmental Assessment: in action - Earthscan, 2004;

THÉRIVEL, R., et.al. Strategic Environmental Assessment. Earthscan Publications Ltd., London. 1992.

THÉRIVEL, R; PARTIDÁRIO, M. R.. The Practice of Strategic Environmental Assessment. London: Earthscan, 1996.

VEIGA, J. E. da. Territórios Para um Desenvolvimento Sustentável. Disponível em <http://www.econ.fea.usp.br/zeeli/Textos/ArtigosCientificos/2006_Territorios_Ciencia_Cultura_58_1_j an_mar.pdf>. Acesso em 11/03/2010

VILLAÇA, F. Dilemas do Plano Diretor. In: CEPAM. 0 município no século XXI: cenários e perspectivas. São Paulo: Fundação Prefeito Faria Lima - Cepam, 1999.

VILLAÇA, F. Espaço intra-urbano no Brasil. São Paulo: Studio Nobel: FAPESP: Lincoln Institute, 2001.

VILLAÇA. F. O que todo cidadão precisa saber sobre habitação. São Paulo. Ed. Global, 1986. 
